\title{
الحركات العربية بين القدماء والمحدثين على ضوء مناهج اللسانيات
}

د.ياسر سر الختم عبد الحفيظ*

ملخص:

يستعرض هذا البحث " الحركات العربية بين القدماء و المحدثين على ضوء

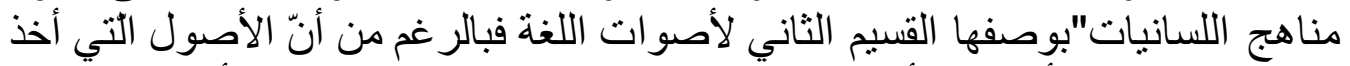

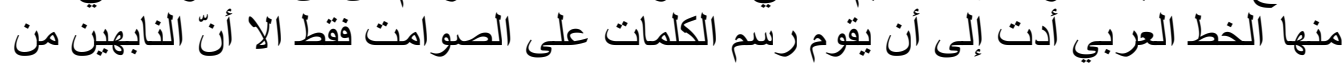

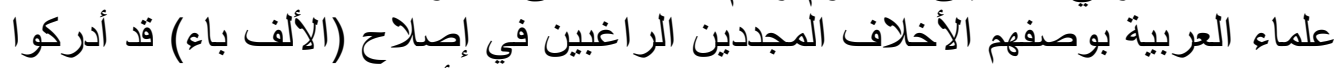

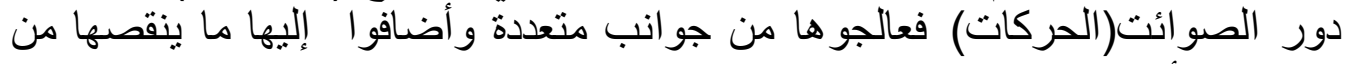

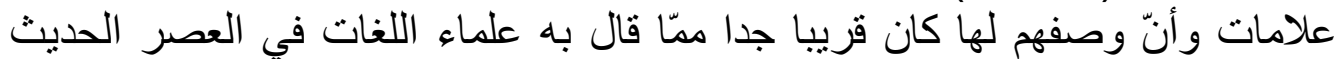

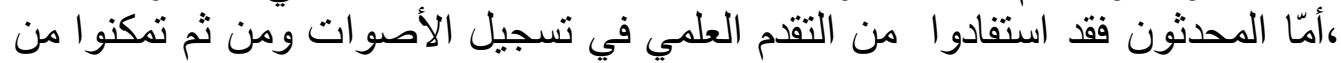

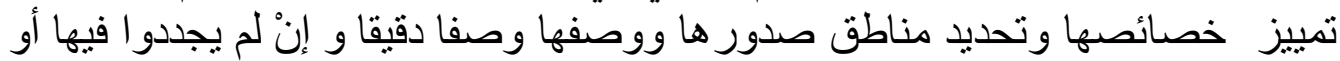
يعالجو ا رسمها كما فعل القدماء

أمّا أهل الأداء أو القرّاء فقد ركزوا جهدهم على كيفية نطق الحركات وأدائها

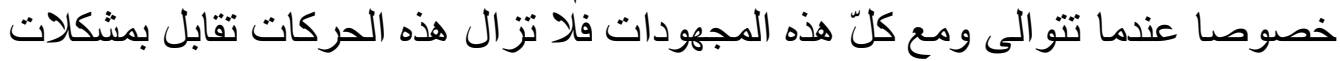

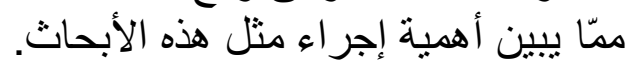

مقدمة:

الحمد لله رب العالمين والصلاة ة السلام على أثرف خلق الله أجمعين سيدنا محمّد و على آله وصحبه أجمعين.أمّا بعد:

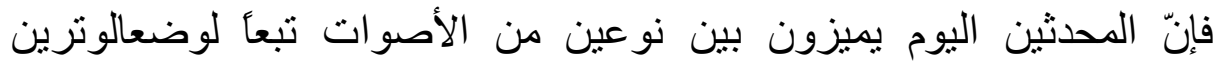

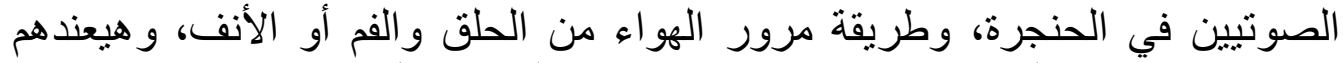
صامتة وصائتة، فالصامت (Consonant) هو الصوت فوت الذي (يضيق عند صدوره

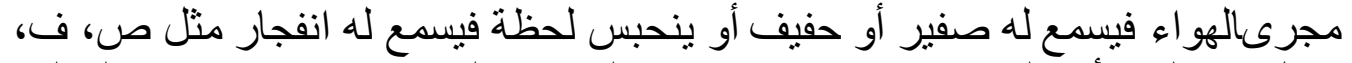

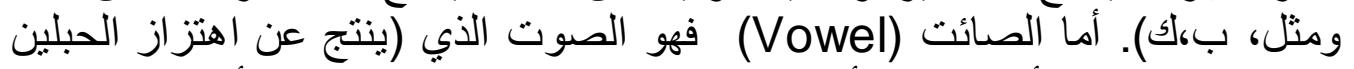

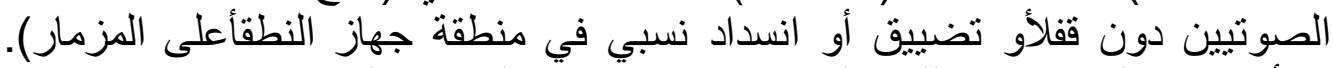

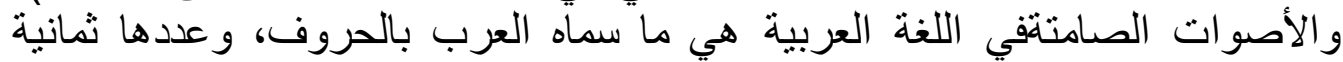

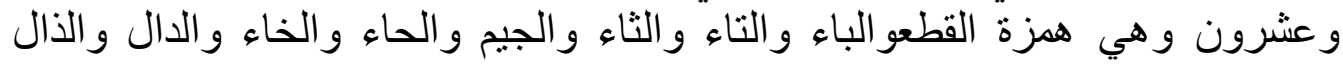

* عضو هيئة التذريس بكلية التربية جامعة بنغازي. 


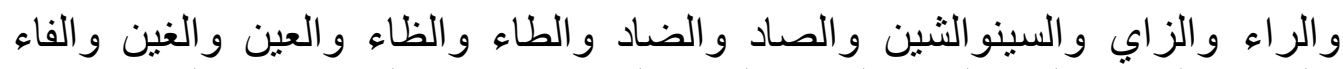

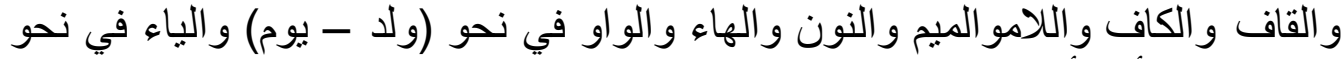

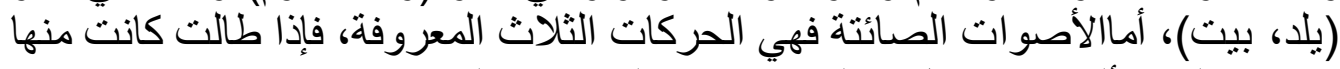
حروف المد الألففي نحو قال، والياء في نحو الراتهي، الري، والوات الواو في نحو يدنو.

وقد أطلق العرب على الصامت اسم الساكن والصحيح، وعلىالصائت أسماء

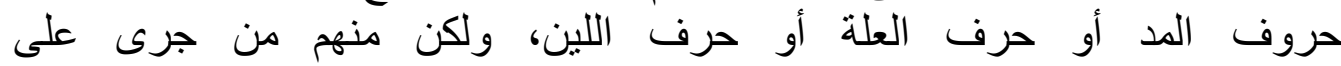

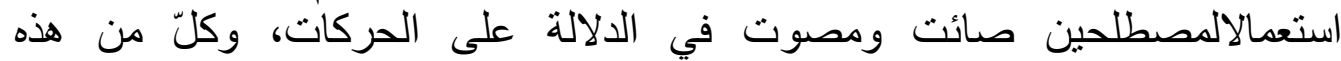
المصطلحات معروف في كتبهم بالمعاني التي استعملها فيها علماء اللغة المحدثون.

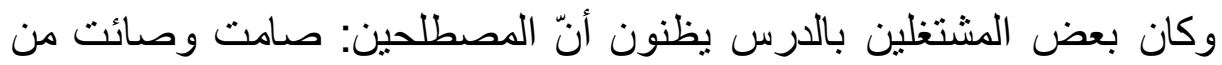

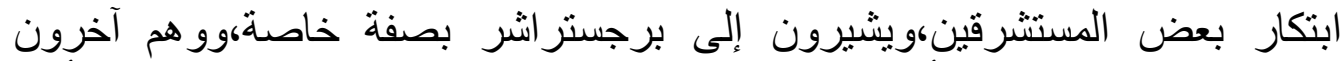

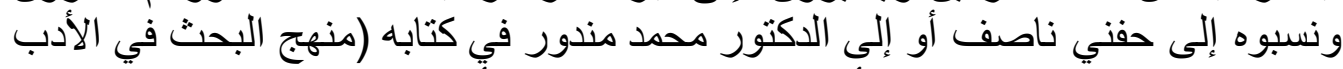

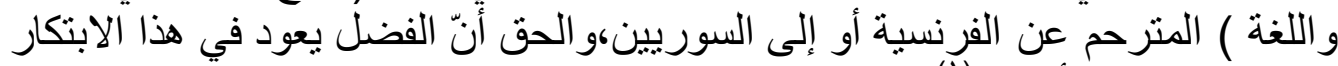
إلى النحاة العرب أنفسهم (')

فابن جني مثلا سمى حروف المد - و هيحركات طويلة - بالحروف المصونة،

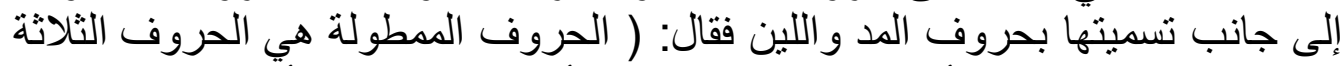

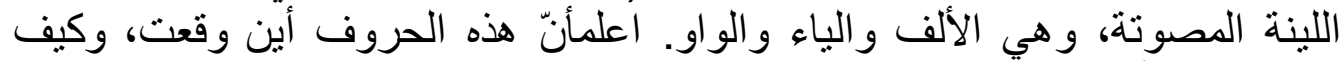

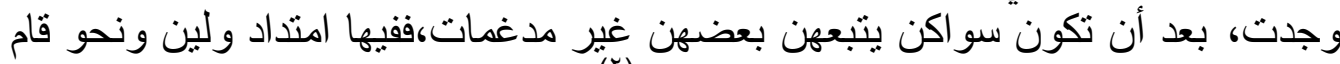

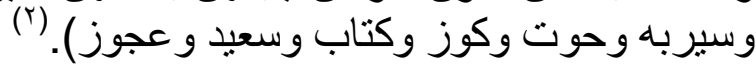

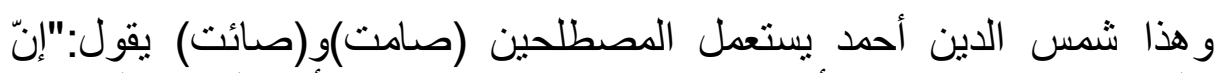

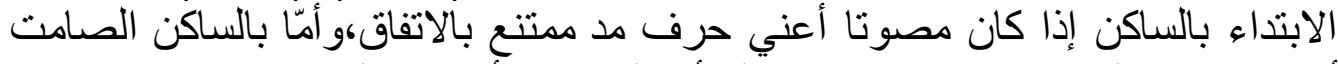

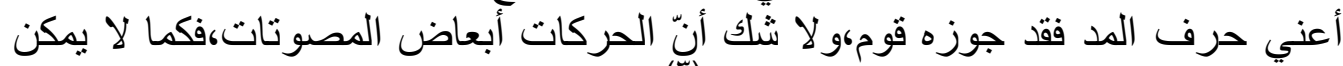

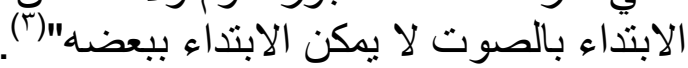

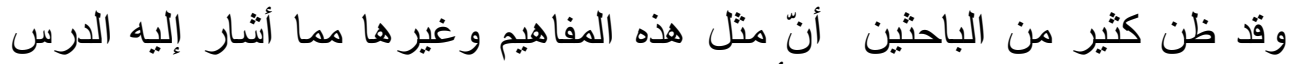

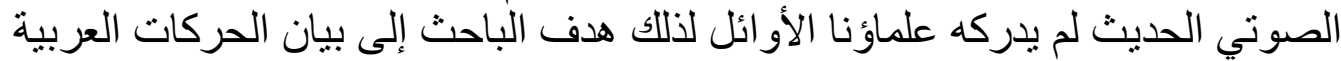
على ضو ء مناهج اللسانيات.

ويمكن تقسيم هذا الموضوع)(الحركات العربية بين القدماء و المحدثين على ضوء مناهج اللسانيات) إلى عناصر : أو لا.الحركات ونظم الكتابة العربية. 

سادسا. مقاييس أصو ات اللين. سابعا. الصوائت المعيارية الأساسية عند جونز. ثامنا.وصف الحركات المعيارية الأساسية. تاسعا. الحركات المعيارية الثواني. عاثر ا. الحركات العربية على ضوء الدرس الصوتي الحديث. حادي عثر. وصف الحركات العربية. ثاني عشر. مشكلات الحركات في القديم و الحديث أولا-الحركات ونظم الكتابة العربية الحركة علامة صوتية متغيرة تلحق الصامت "الحرف" عند النطق به لتغير صوته

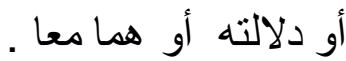

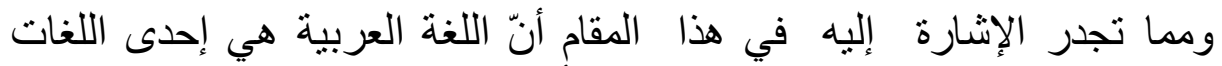

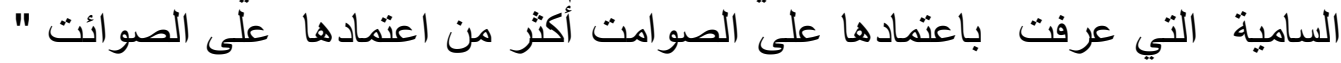

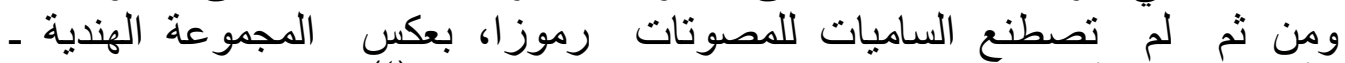

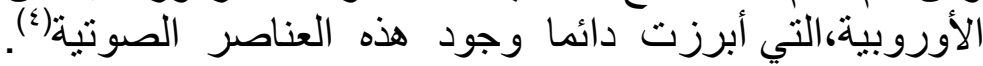

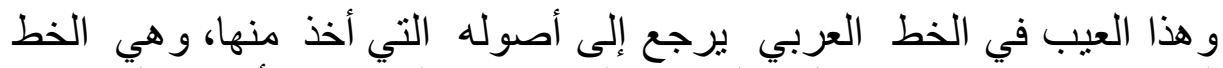

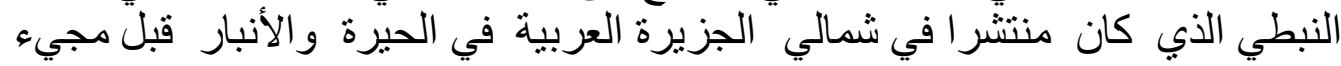

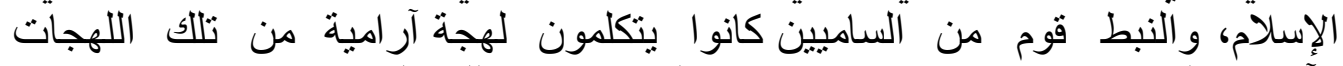

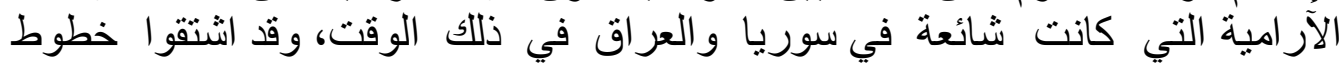

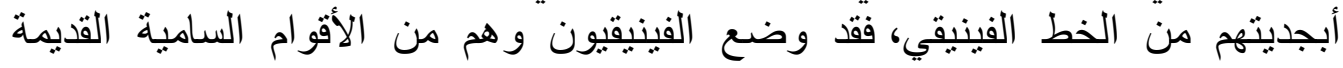




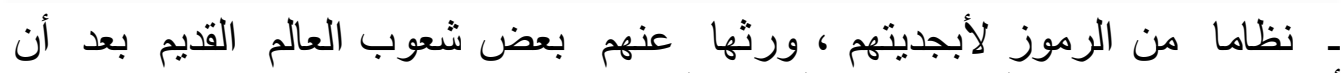
أحدثوا فيها بعض التغييرات لابجم على مر الزمان.

و على الرغم من أن أصوات العلة قصير هاوطويلها أوضح في السمع من الأصوات

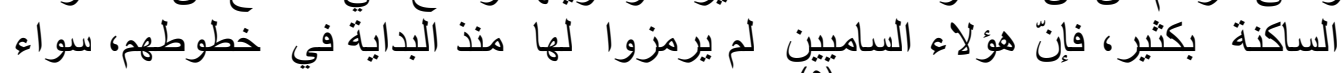

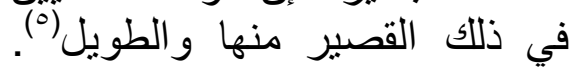

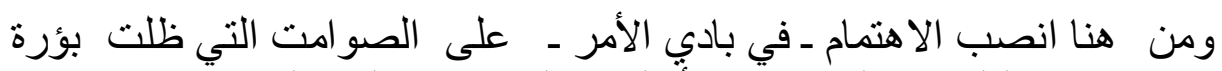

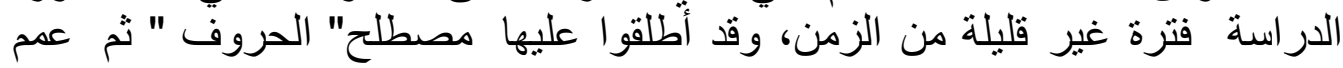

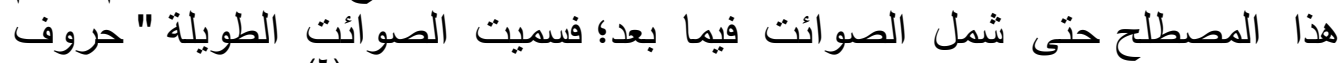

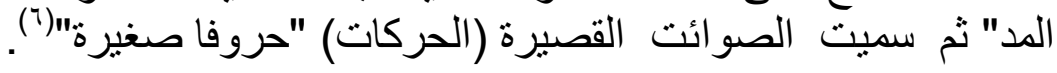

$$
\text { أي أنّ ظهور الحركات في الكتابة العربية مر بمرحلتين :- }
$$

الأولى : ـ ظهور الحركات الطويلة، وقد سماها المتقدمن "حروف المد " ( ألف المد،

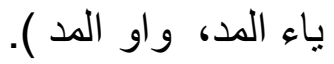

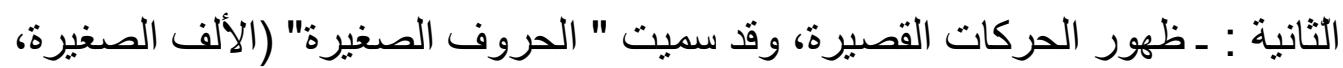
الياء الصغيرة، الواو الصغيرة).ثم سميت بالحركات ( الفتحة، الكسرة، الضمة الصة ).

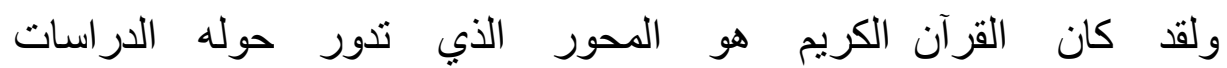

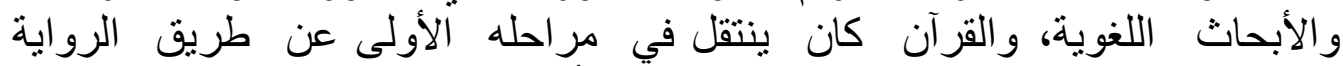

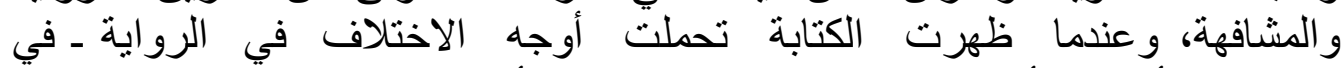

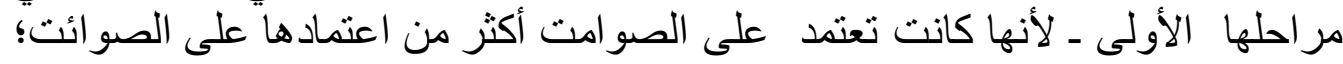

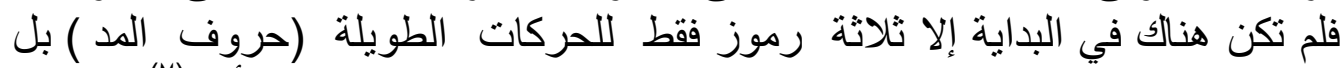

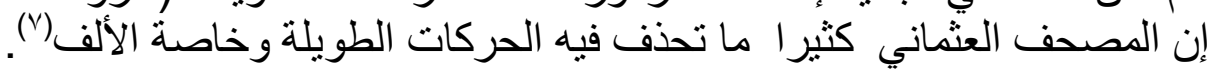

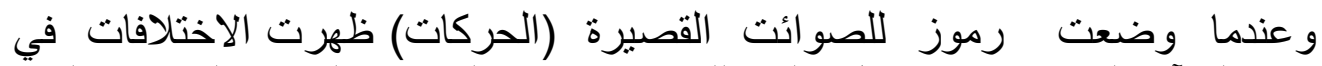
رواية القرآن الكريم، وخير منال على ذلك ما وان ورد في الخطوط العربية القديمة كالخطً

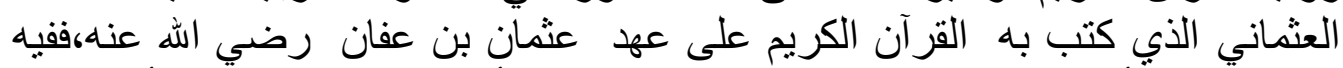

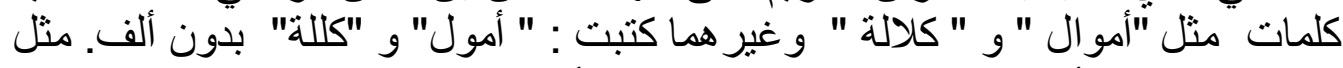

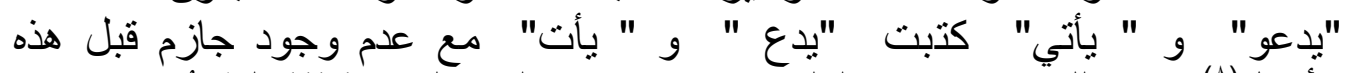

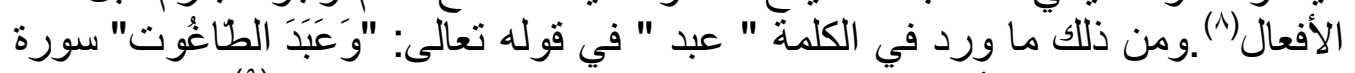

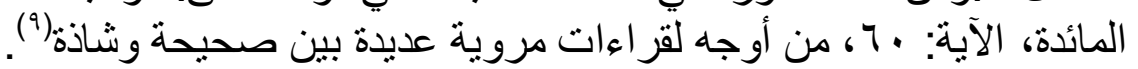

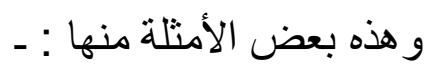




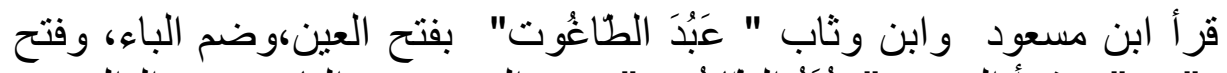

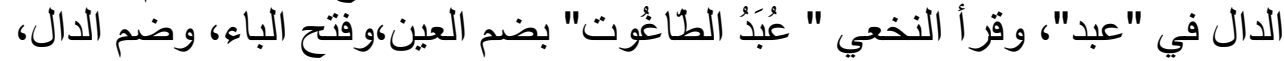

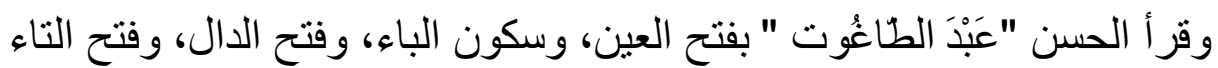

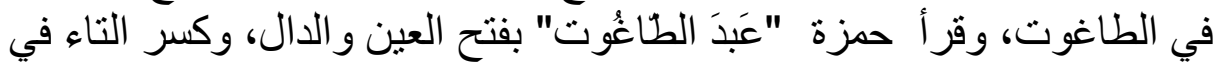
الطاغوت، وقر أ ابن عباس "عُبَدَ الطُاغُوت" بضم العين، وفتح الباء و الدال، وكسر التاء

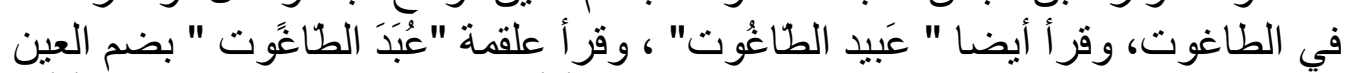

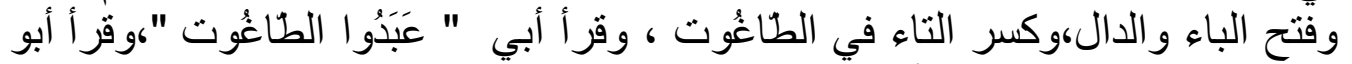

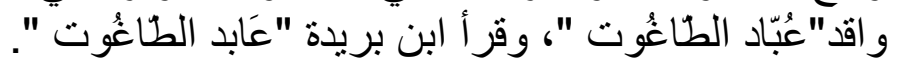

إنّ هذه الروايات على اختلافها وتعددها كانت تتحملها الكلمة " عبد" عندما

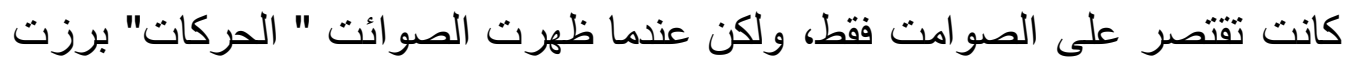

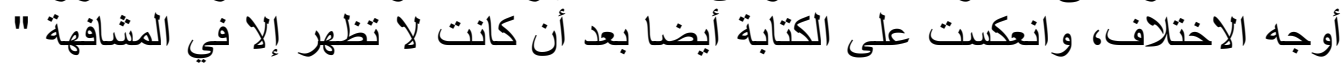
النطق فقط ".

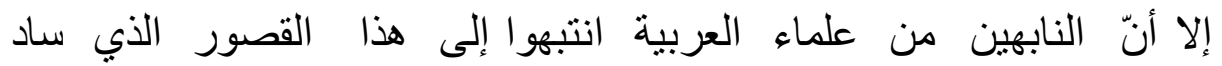

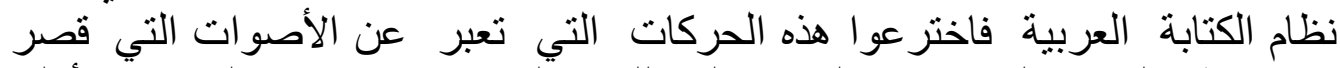

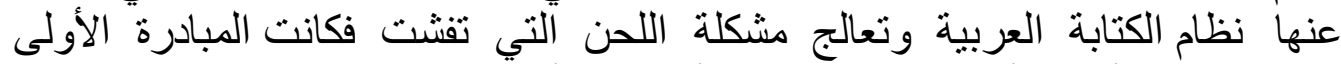

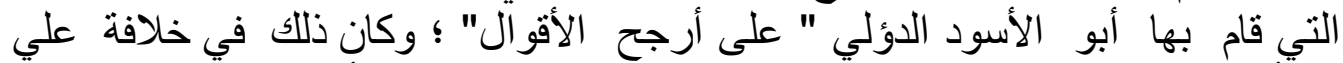

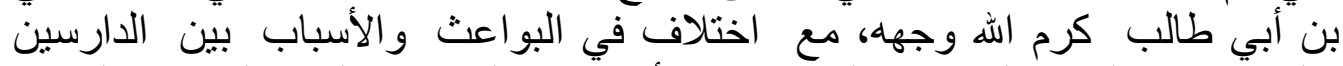

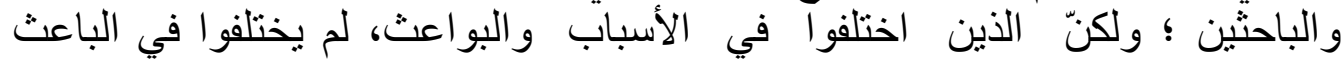

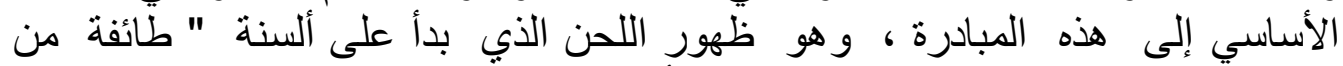

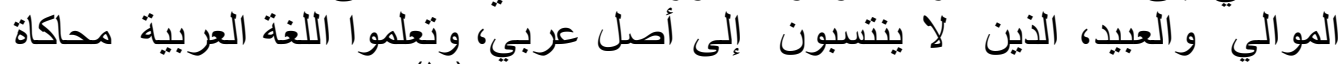

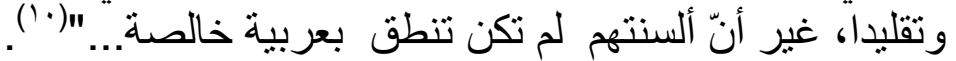

ويعظم خطر اللحن عندما يتسرب إلى العرب الأصلاء، حين يسمع أبو الأسود

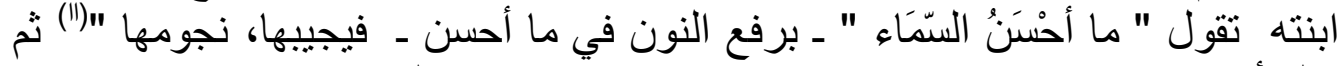

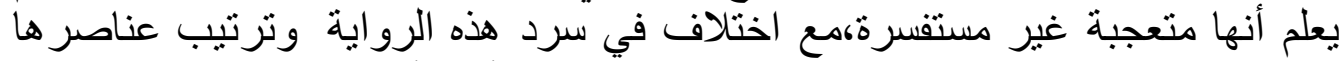

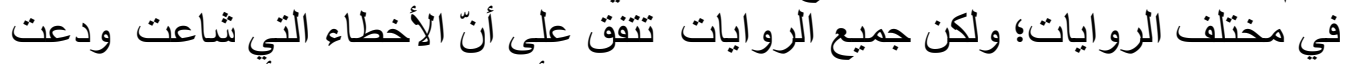

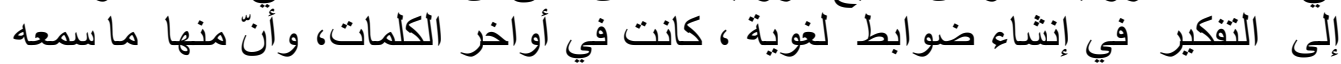
الناس في الكلام العادي، ومنها ما سمعوه في القرآن الكريم.

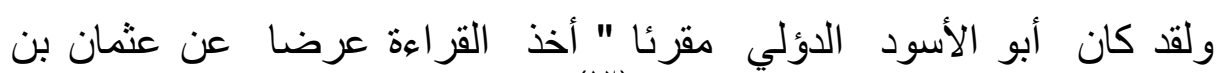

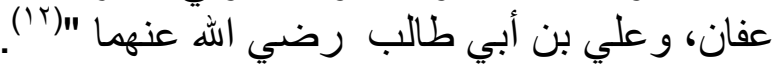




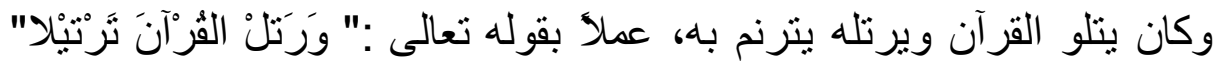

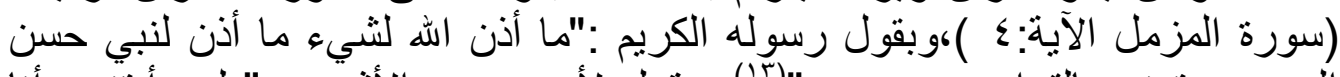

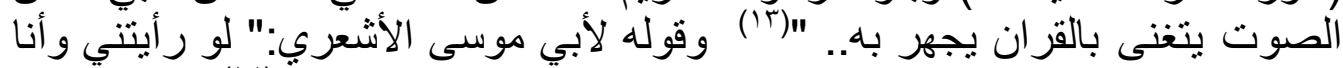

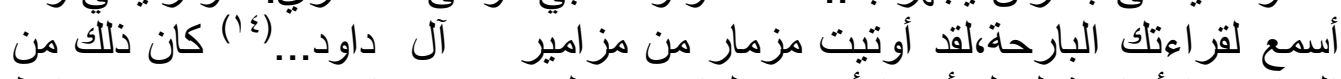

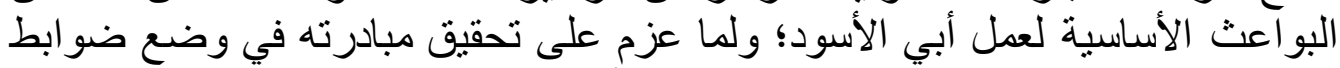

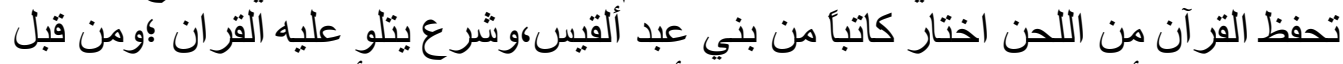

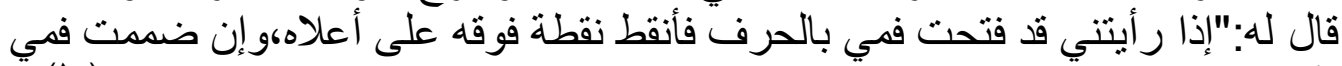

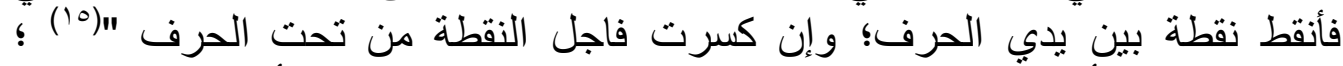

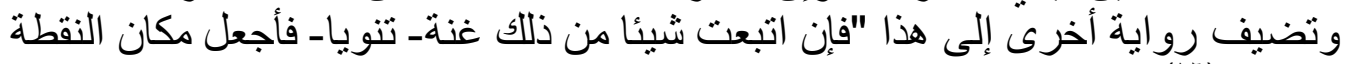

نقطتين" (17)

\section{ومما يلاحظ على عمل أبى الأسود الدؤلي ما يلي:}

1 - أنه نقط المصحف ليهتدي بعمله القراء إلى الأداء الصحيح السليم لكتاب الله؛

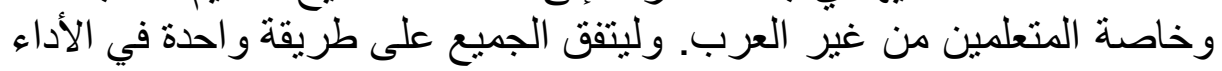

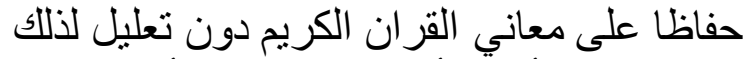

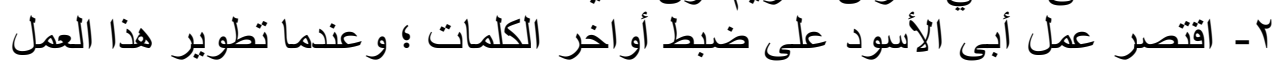

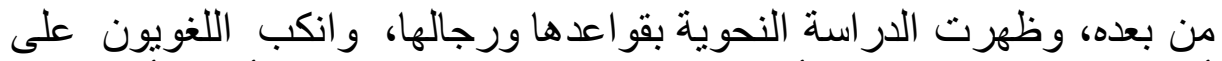

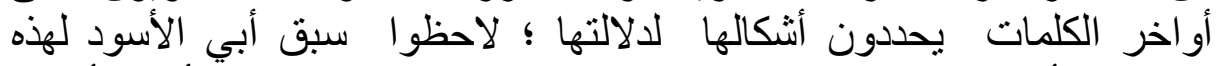

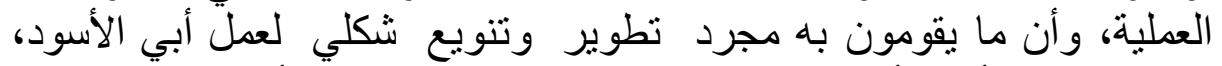

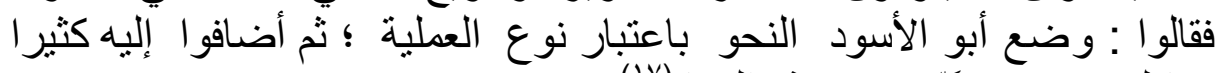

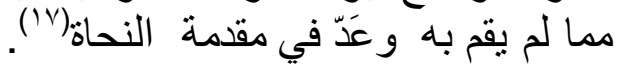

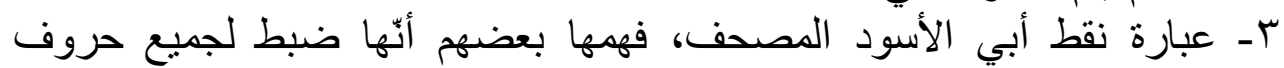
الكلمة؛ ونسبواً إليه طريقة في النقط يظهر عليها التكلف و عدم ملاعمتها لعصره

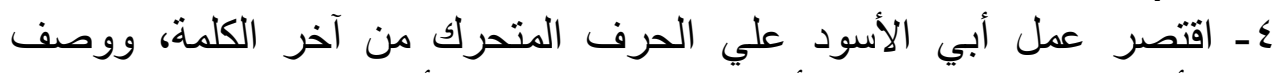

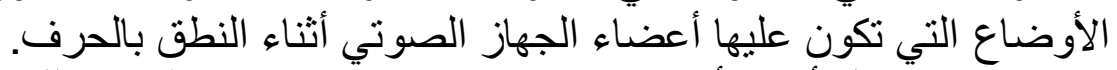

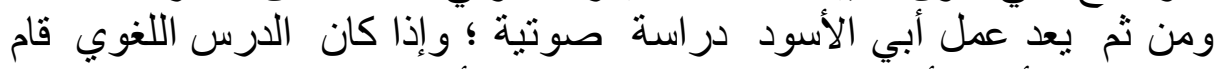

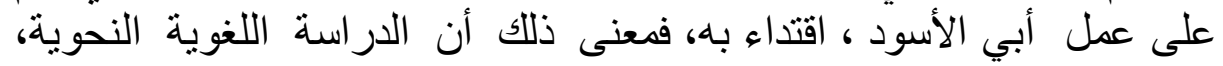
انطلقت منطلقا صوتي الانيا.

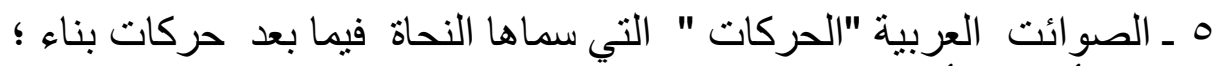

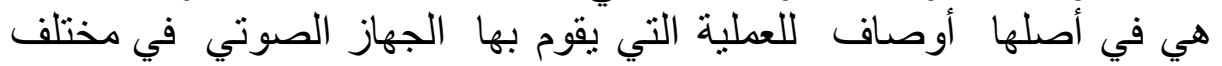

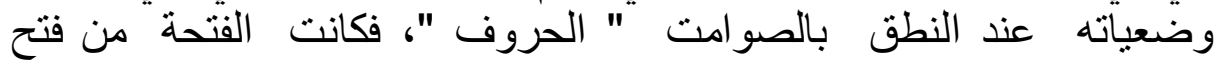




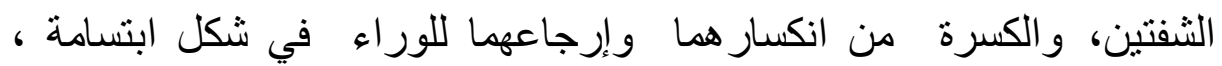

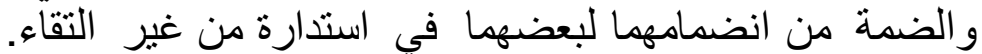

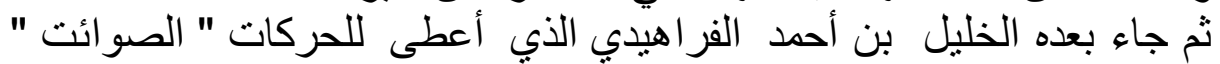

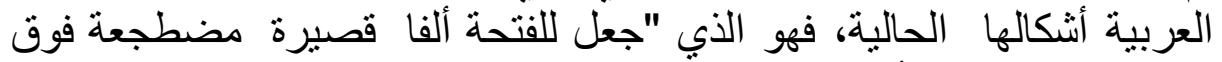

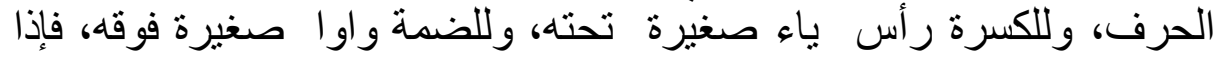

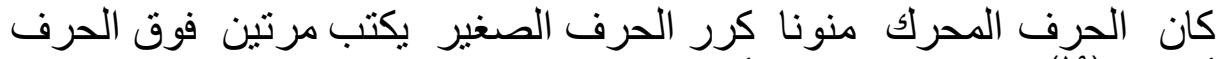

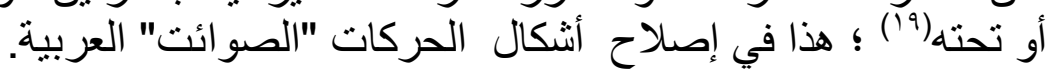

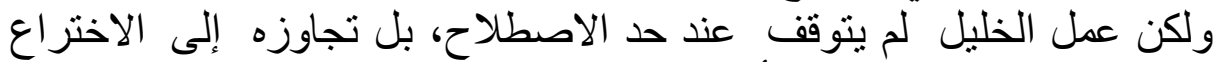

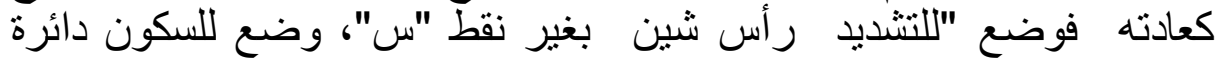

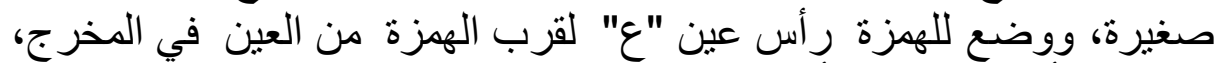

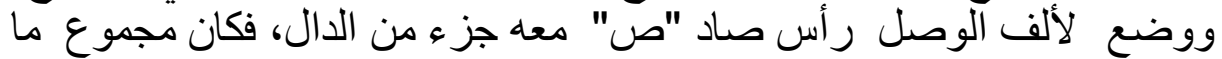

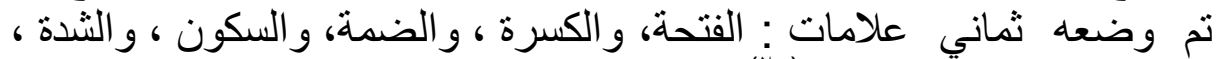

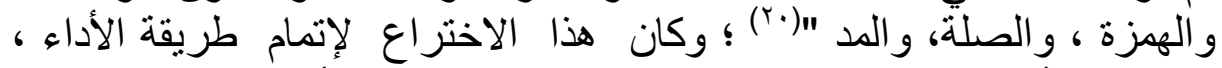

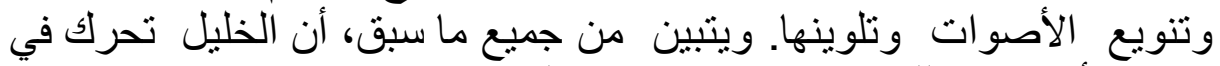

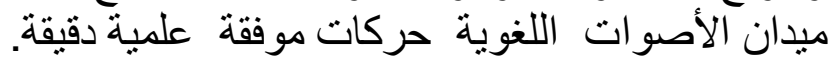
الهتم الخليل بالحركات " الصوائت " العربية فأعطاها أشكالها الحالية

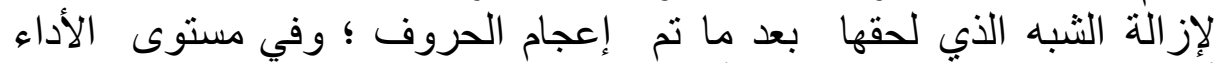

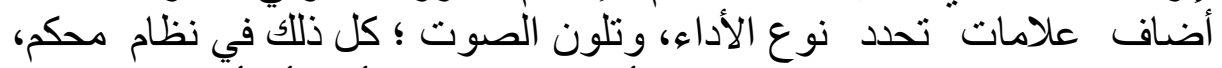

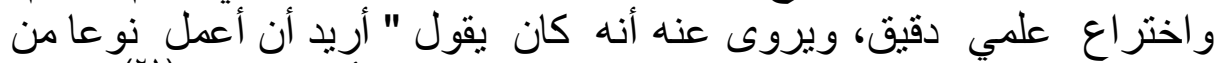

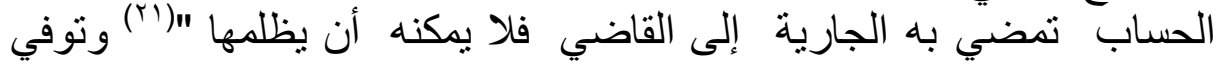

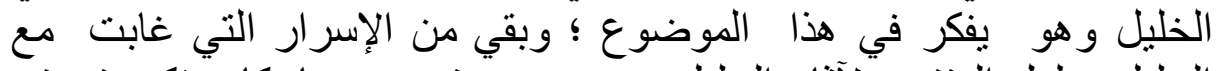

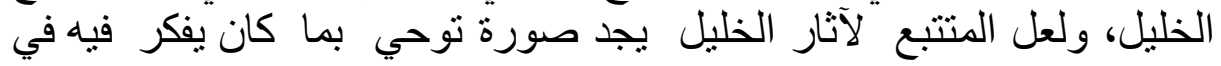

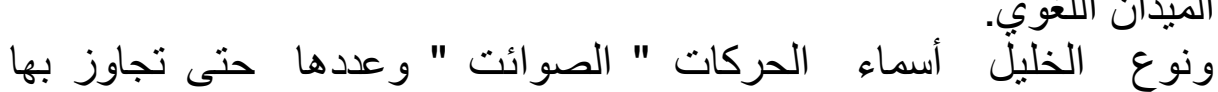

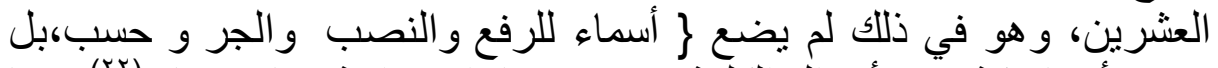

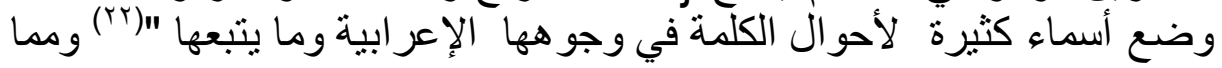

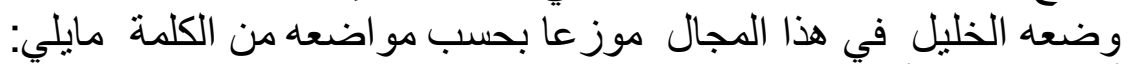

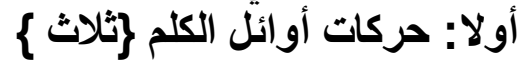
1 ـ التوجيه: مصطلح الحركة التي تكون في صدر الكلمة كلئ كحركة "عين " عمر. r- القصر: مصطلح الحركة التي تكون في في أونئل الكلمة الصحيحة كحركة

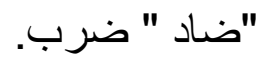

بـ الإشمام: حركة أو ائل الكلمات المعتلة، كحركة "قاف " قيل.

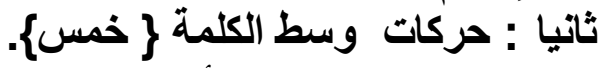
ا ـ الحشو: حركة وسط الأسماء كحركة "جيم" رجل. 
r ـ التسكين: حركة وسط الأفعال كحركة "فاء " يفعل.

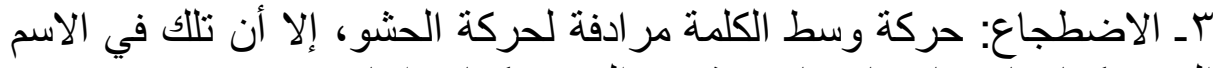

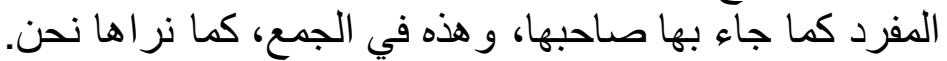

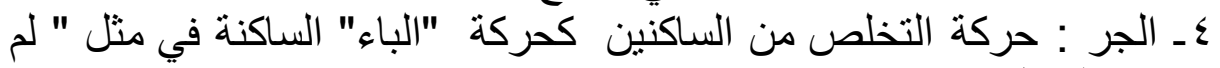

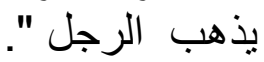
هـ التفخيم: مصطلح الحركة التي تقع على الألفات في وسط الكلمات في مثل " ألف" صام، وتقابلها بالتضاد الإمألة.

ثالثا: حركات أواخر الكلمات $\}$ ثلاث عشرة الركة

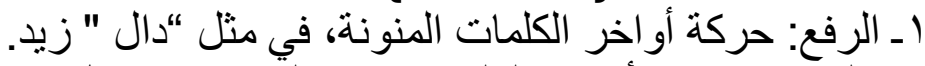

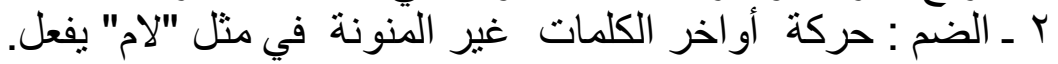

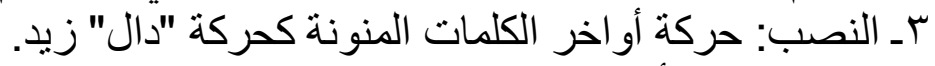

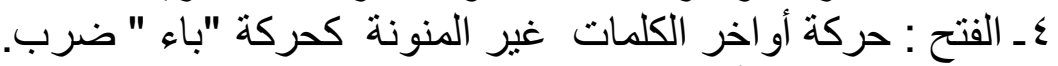

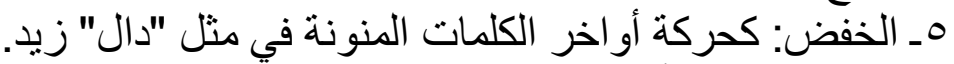

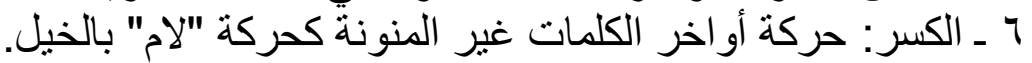

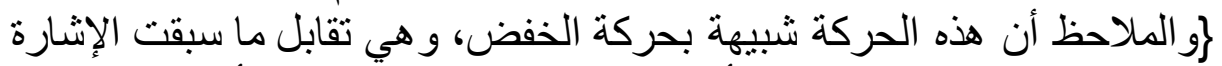

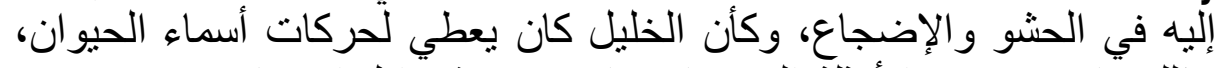

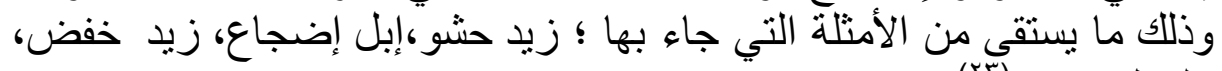

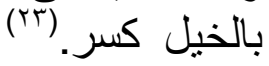

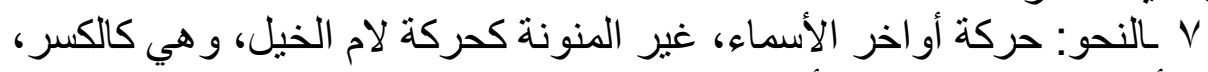

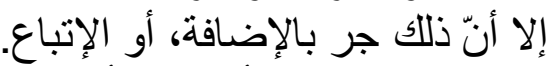

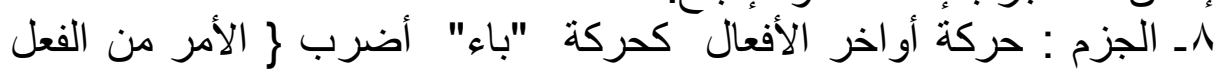
ضرب. 9 ـ الإرسال: حركة أو اخر الكلمات المهوزة في مثل "قر أ" في الماضي.

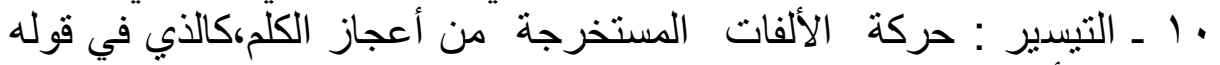
تعالي : :فأضلونا السبيلا"؛ و هي ما يسميها العروضيون الأفئ بحركة الإشباع.

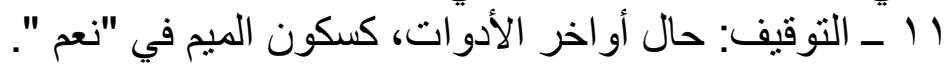

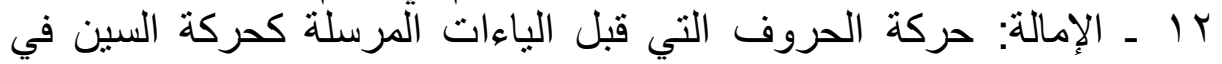

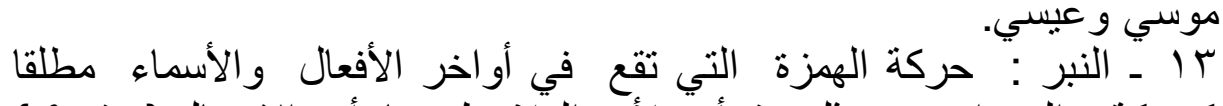

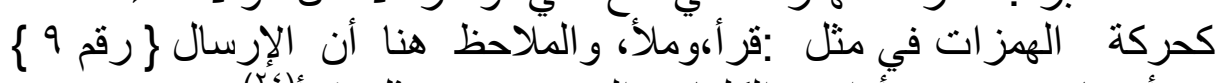

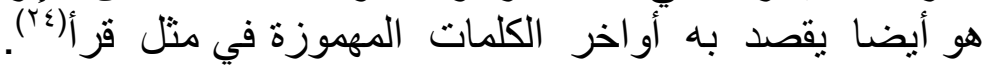

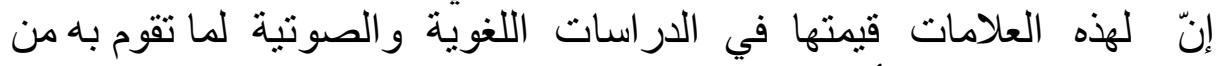
وظائف في التركيب أهمها : فئهات 
ا ـ أنها تحدد موضع الحرف من خلال ذكر علامته، صدر أو حشو أو أو أو عجز ا.

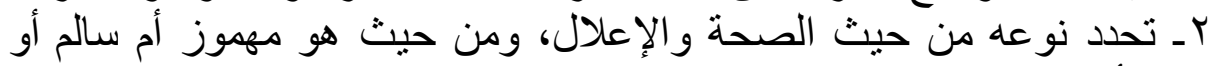

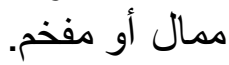

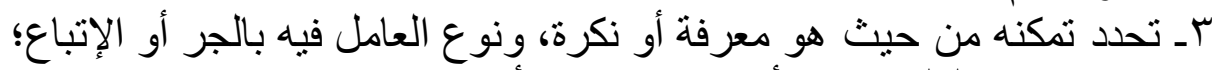

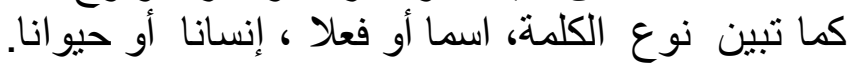

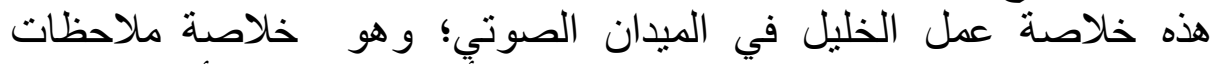

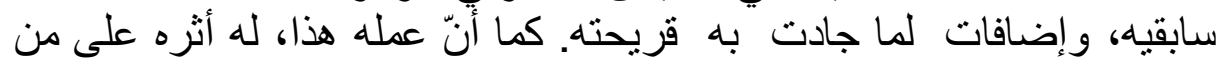

$$
\text { جاء من بعده. }
$$

\section{ثانيا-علاقة الحركة بالحرف :-}

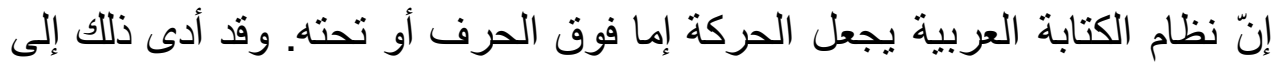

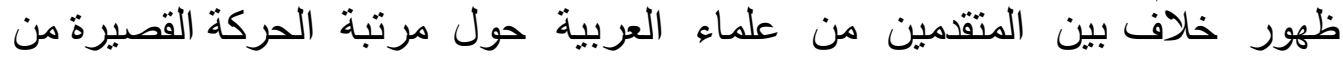
الحرف ؛ هل هي قبل الحرف أوف أو معه أو بعده؟

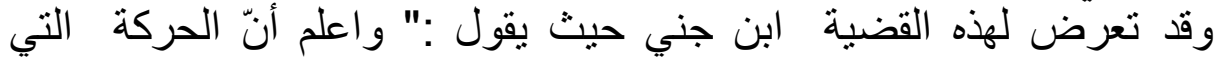

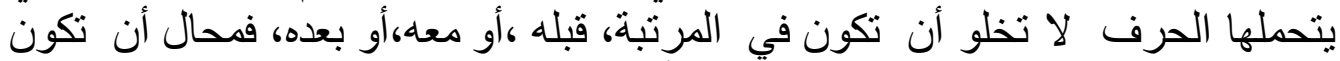

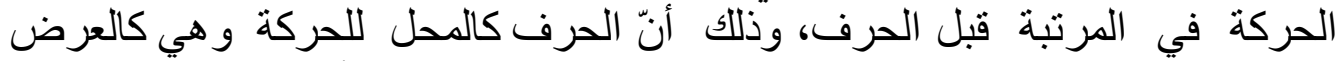

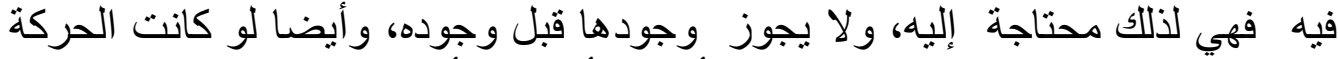

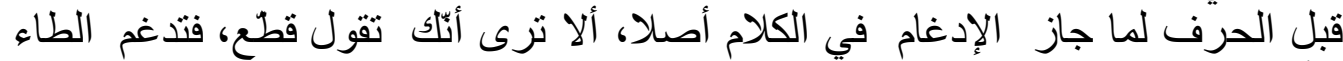

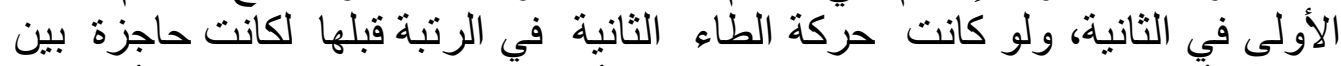

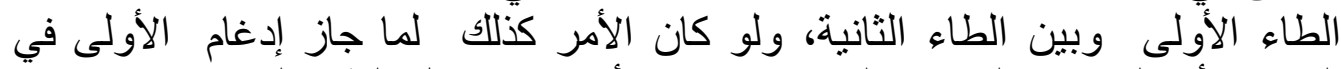

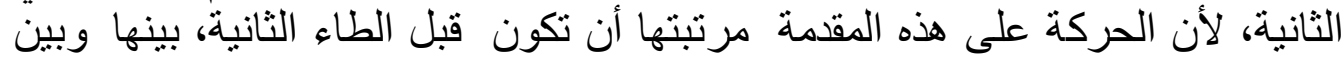

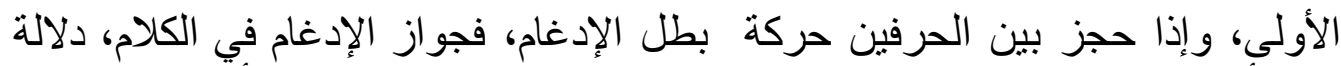

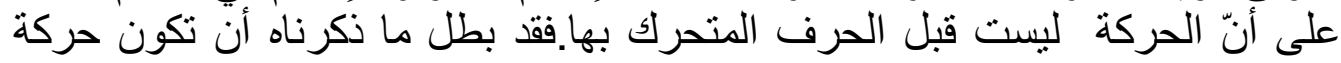

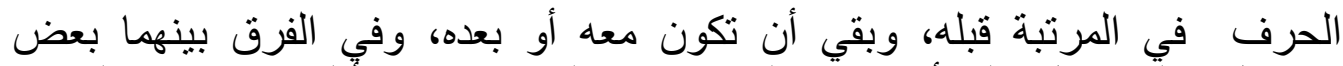

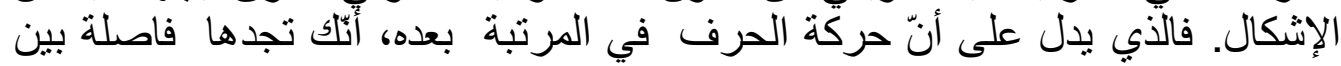

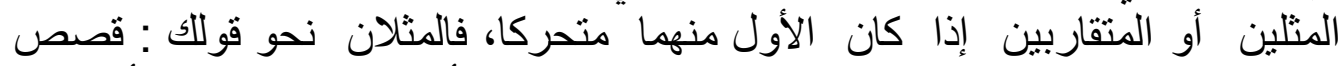

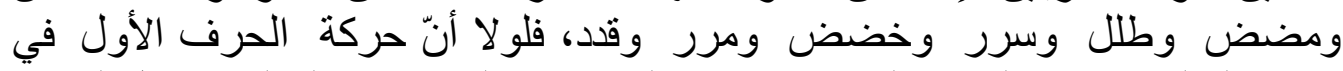

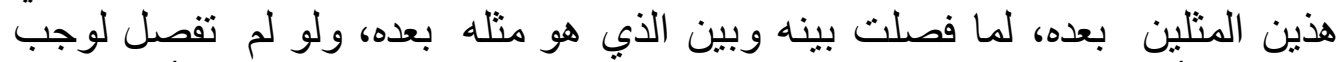

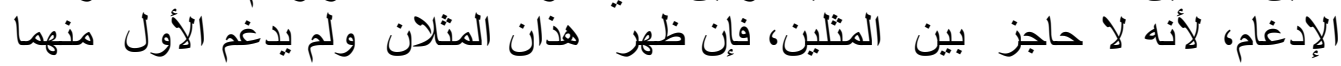

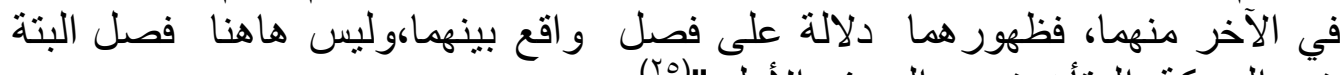

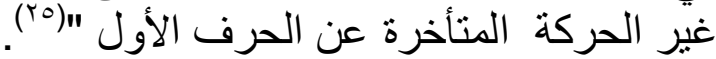

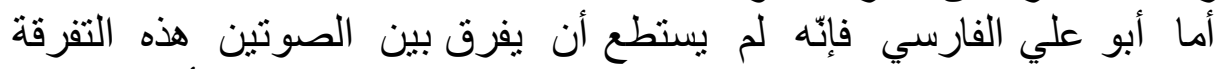

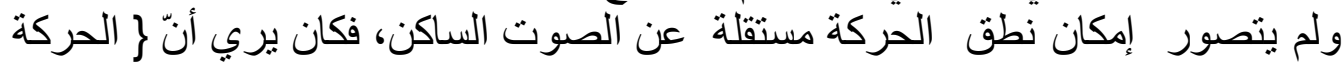




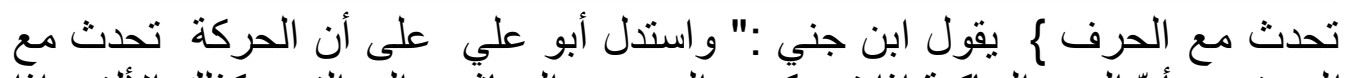

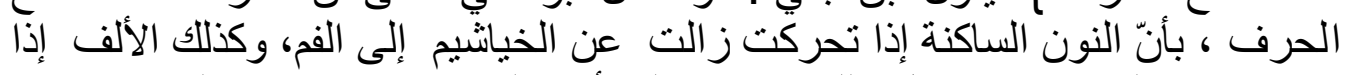

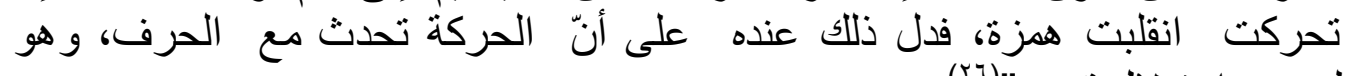

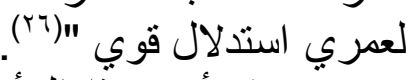

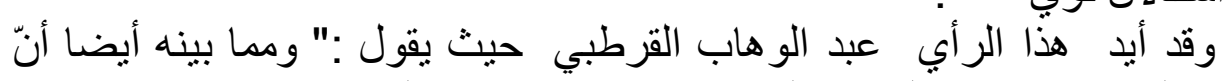

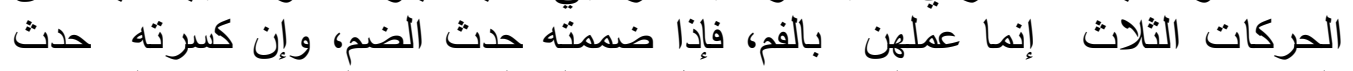

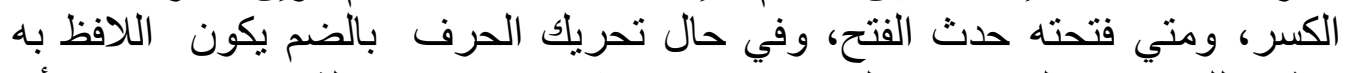

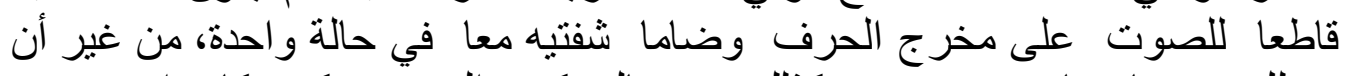

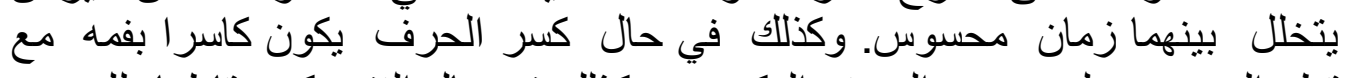

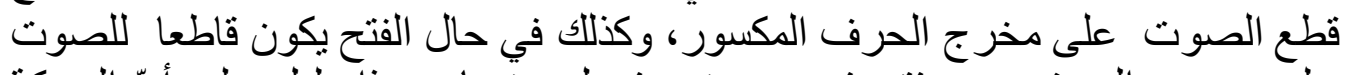

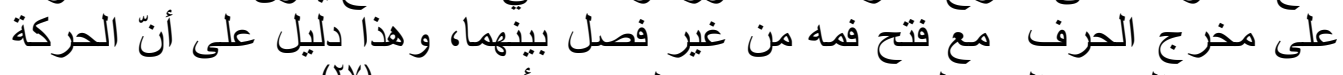

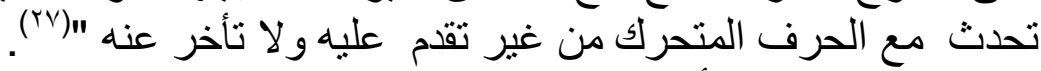

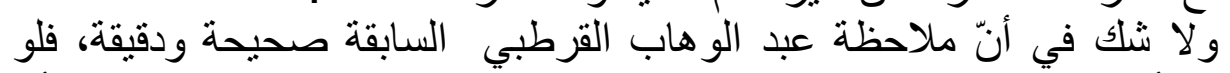

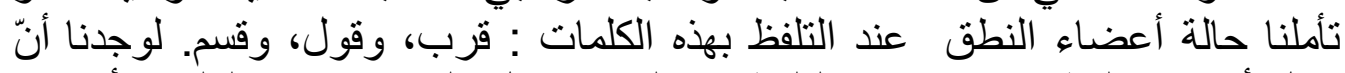

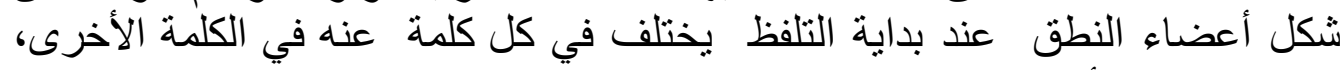

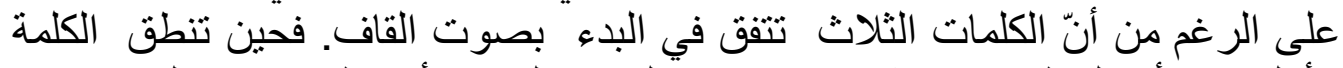

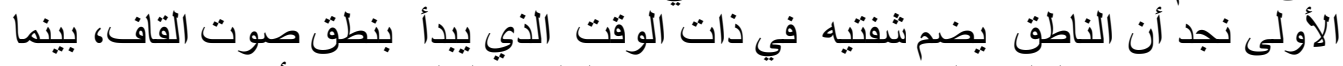

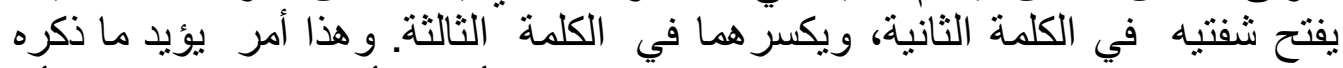

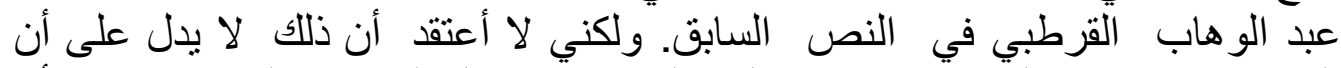

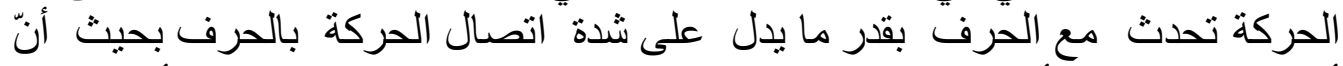

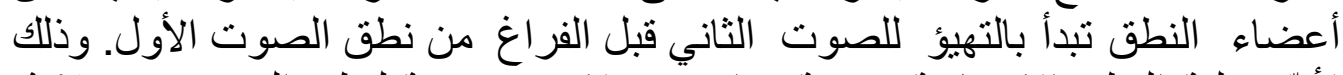

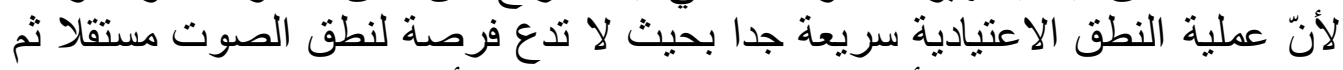

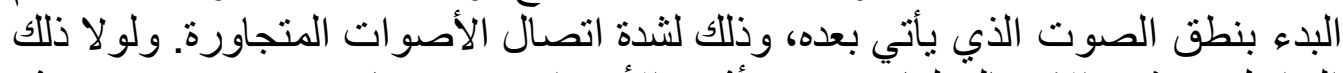

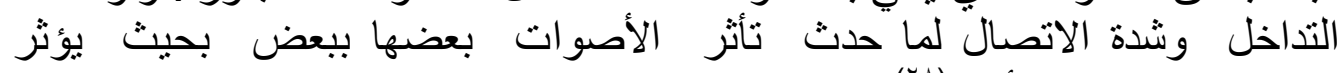

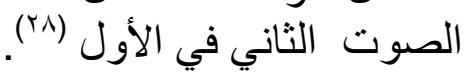

ورغم أنّ ابن جني يعجب برأي أستاذه الفارسي وبدليله حيث يصفه بالاستدلال

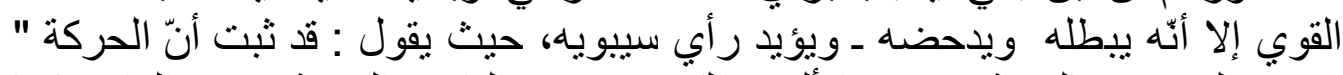

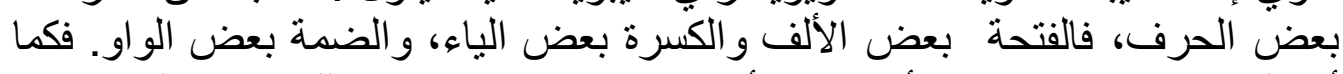

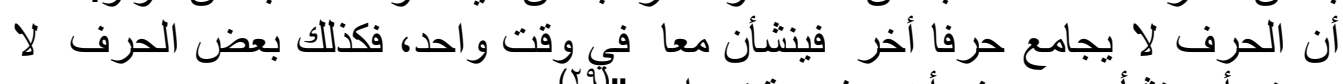

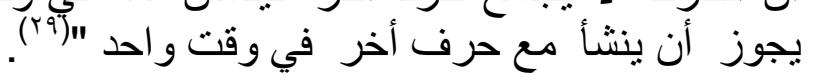

و الحقيقة أن هذا الدليل ينسجم مع الدر اسات الصوتية الحديثة. إذ إنّ " الحركات

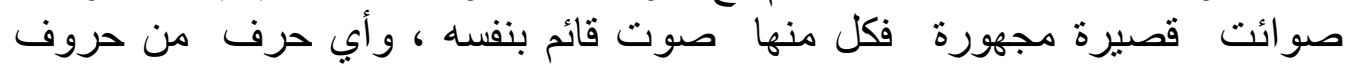


مجلة معالم الدعوة الإسلامية المحكمة العدد (الثامن)- صفر Vr أ ا هـ / ديسمبر 10 • ب م

المعجم صوت مستقل أيضا فكيف يتصور خروج صوتنين مختلفين في آن واحد،

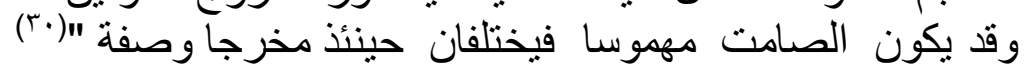
ثالثا_كيفيّة نطق الحركات :-

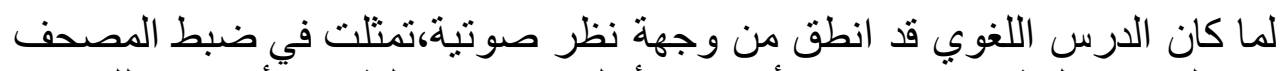

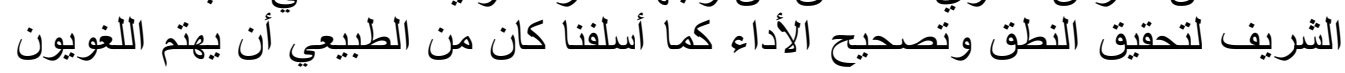

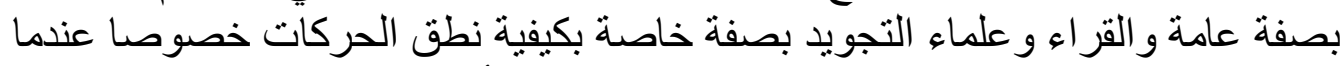
تتو الى لما بينها وبين الحركات من تقارب وحين تجاور أصوات الليفة نطف اللين و المد خاصة. وفي ذللك يقول ابن جنى :"ويدلك على أنّ الحركات أبعاض لهذه الحروف، أنك فئك

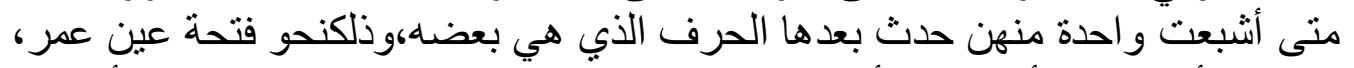

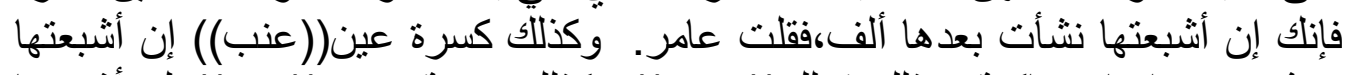

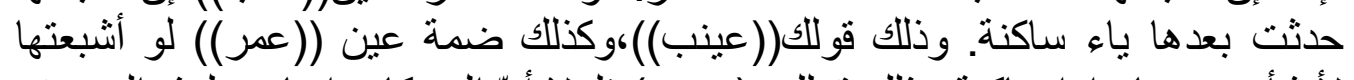

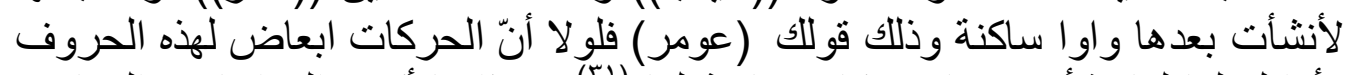

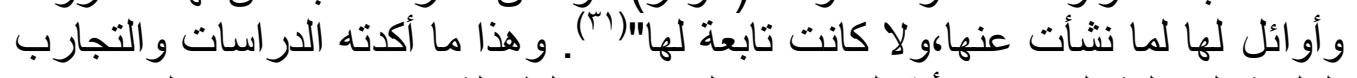

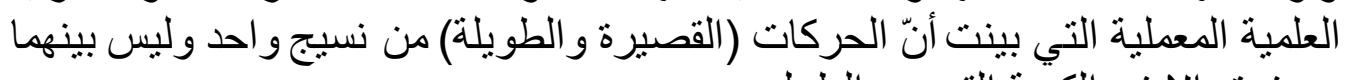

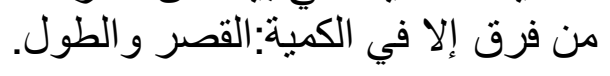

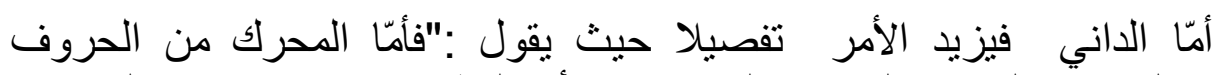

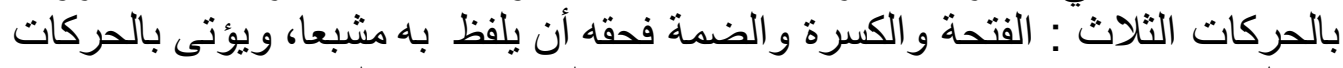

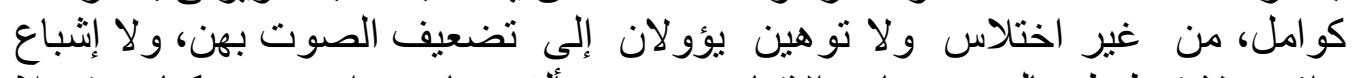

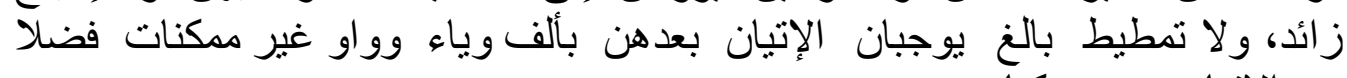

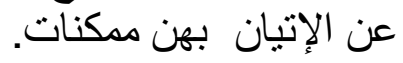

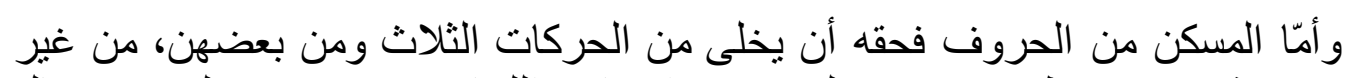

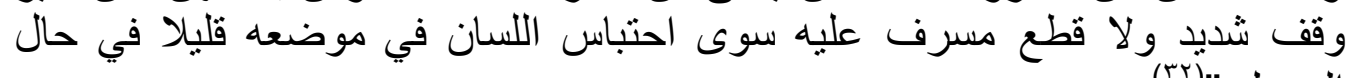

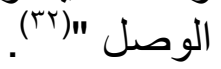

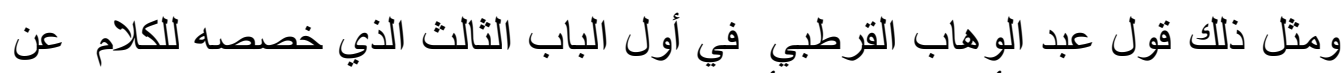

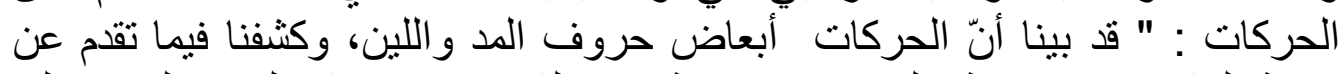

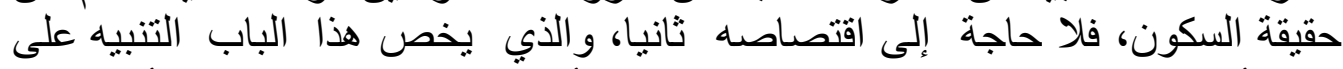

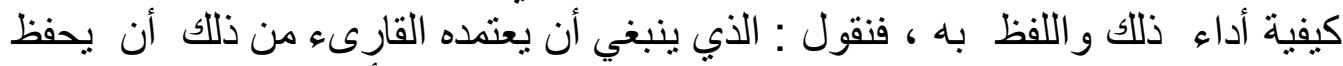

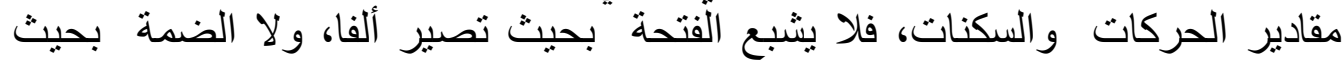

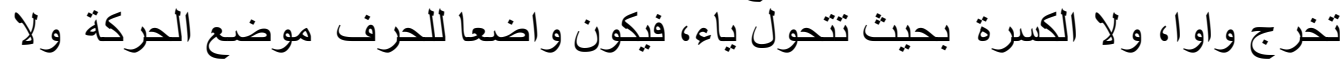


يو هنها ويختلسها و ويبالغ فيضعف الصوت عن نأديتها ويتلاشى النطق بها وتتحول

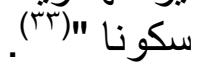

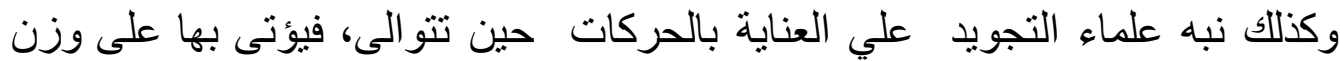

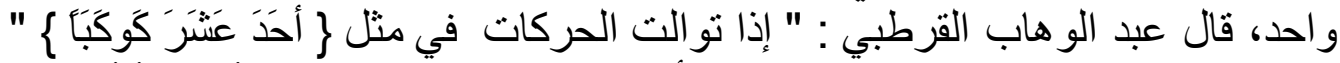

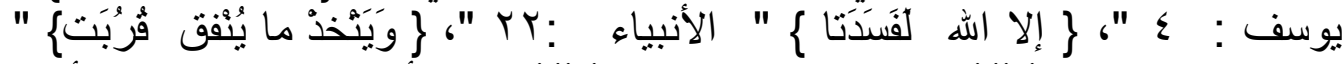

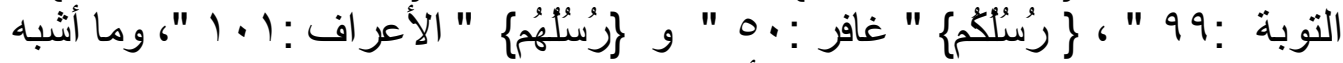

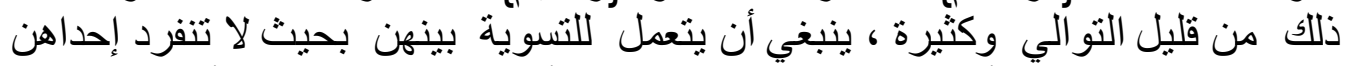

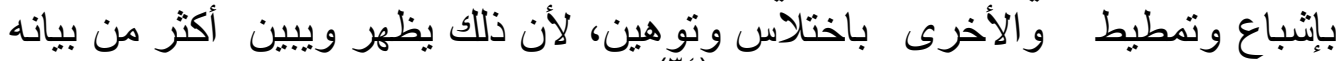

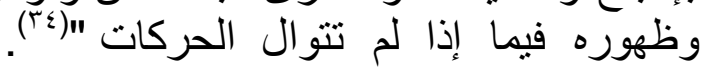

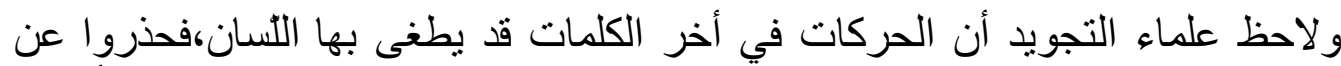

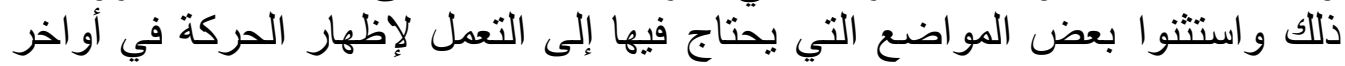

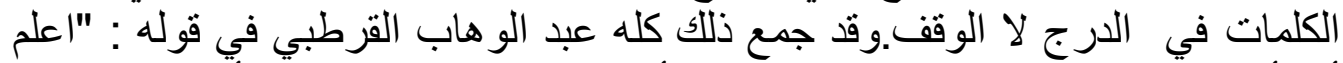

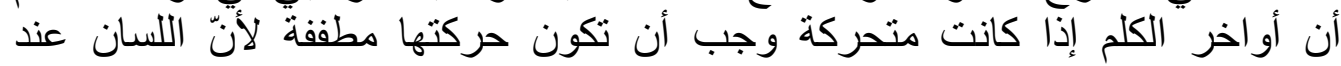

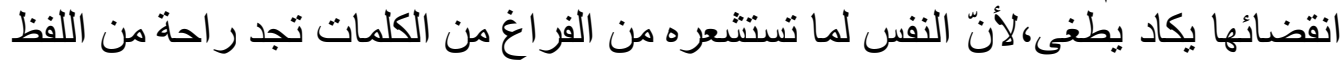

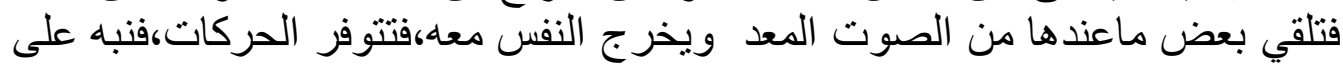

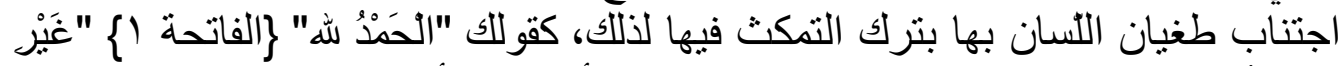

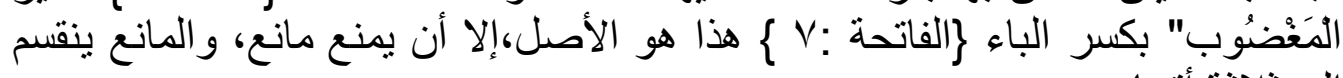

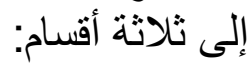

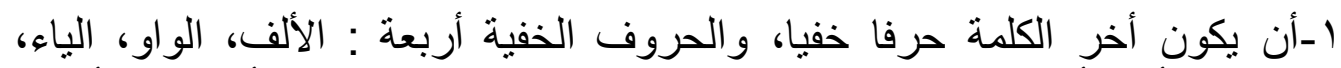

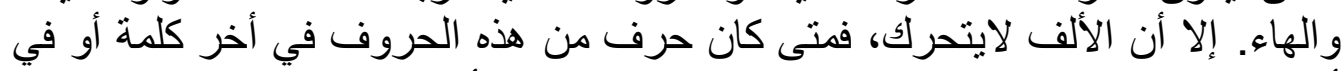

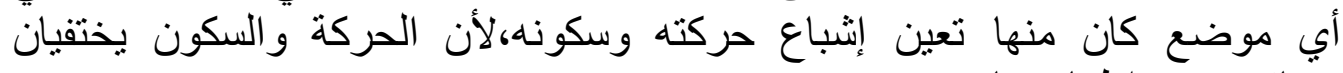
بحفائه،فتعين إظهار هما.

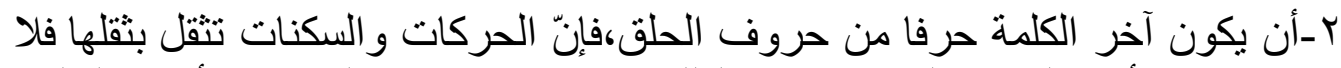

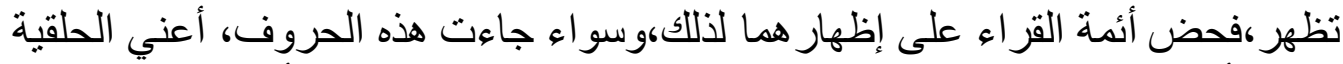

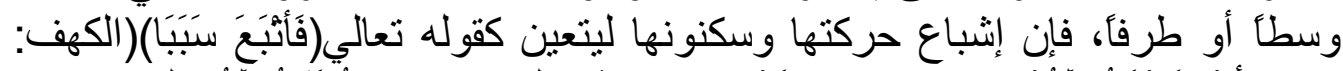

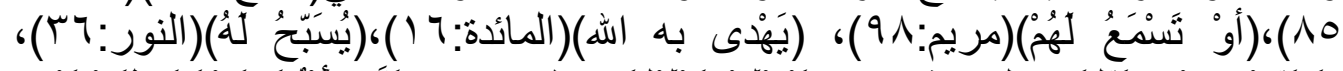

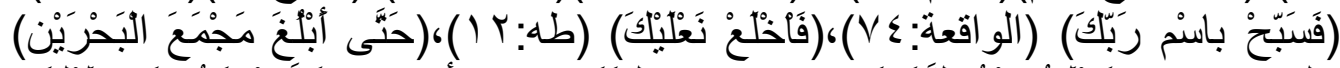

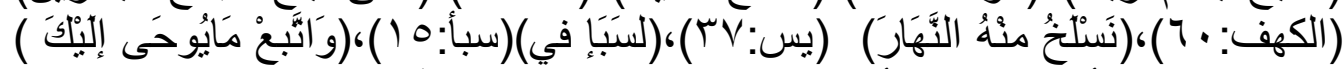

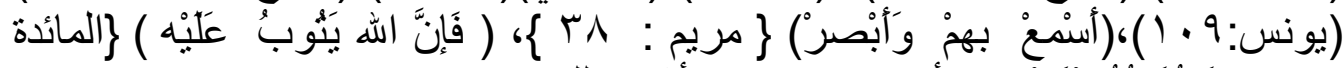

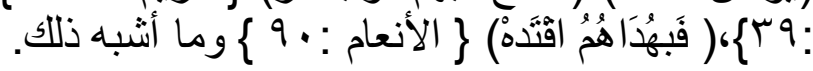




\section{الثالث:- اجتماع حرفين مثلين في آخر الكلمة وأول أخرى، كقوله تعالى:}

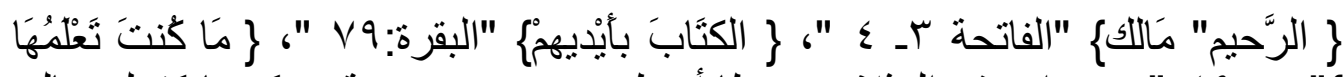

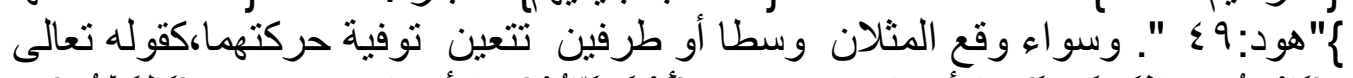

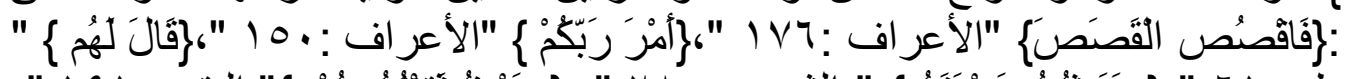

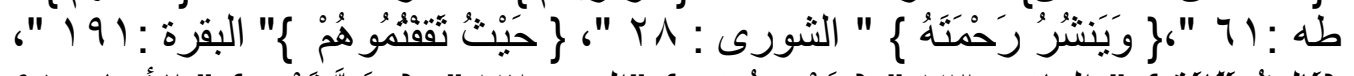

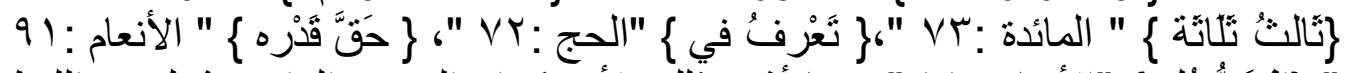

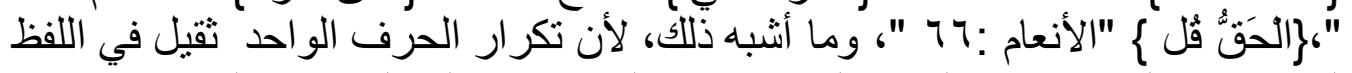

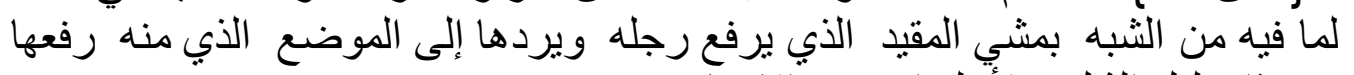
ـ و هذا دليل الثقل، ولأُجله استخف الإدغام.

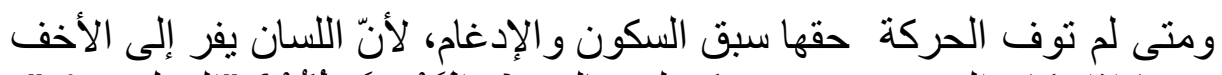

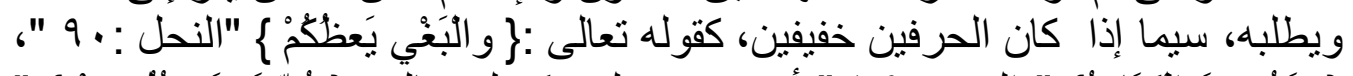

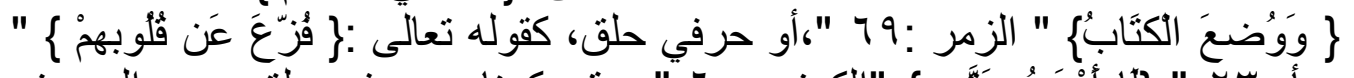

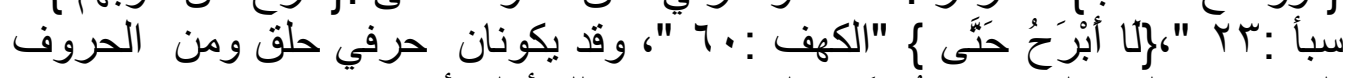

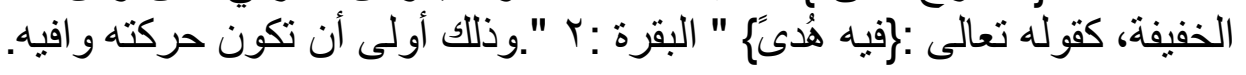

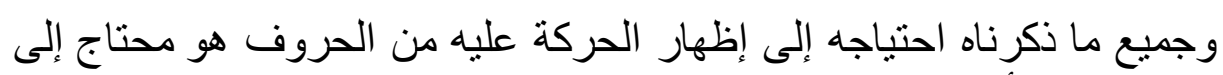

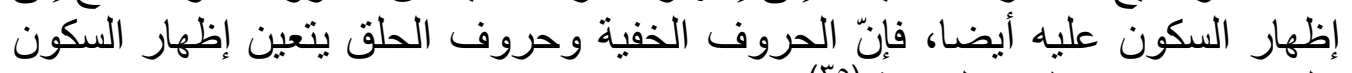

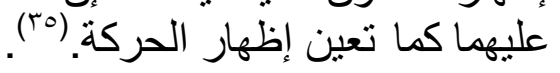

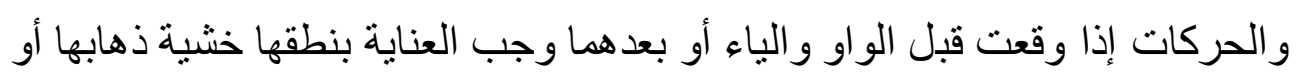

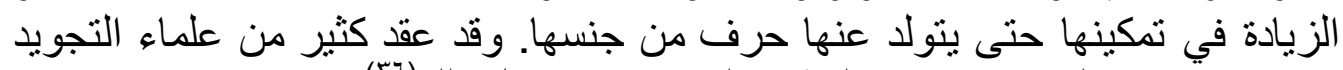

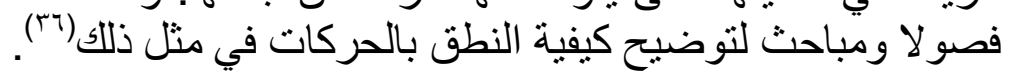

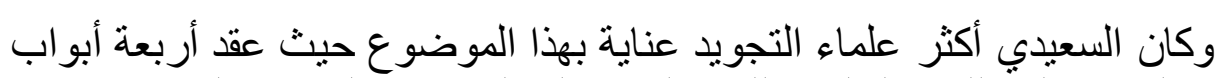

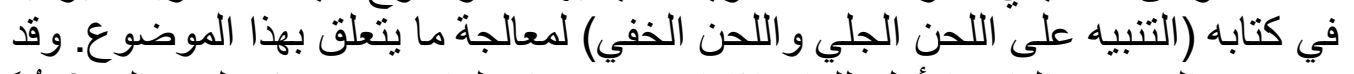

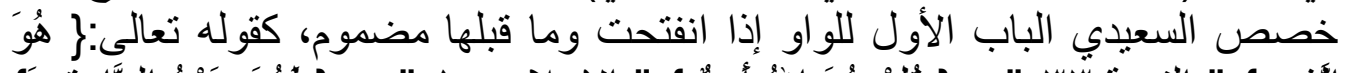

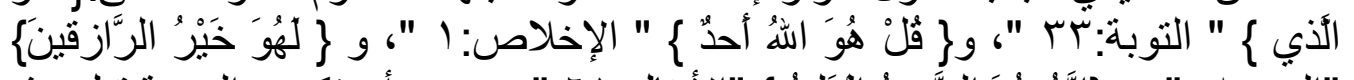

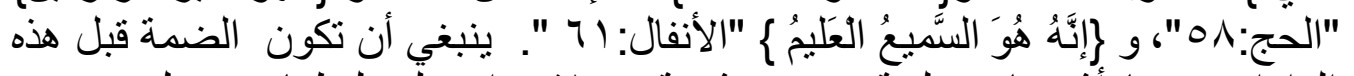

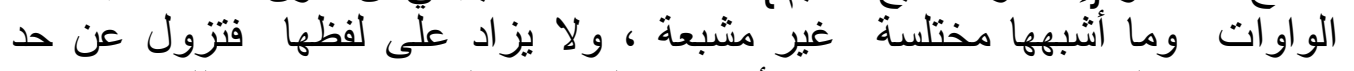

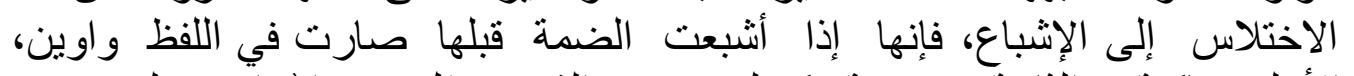

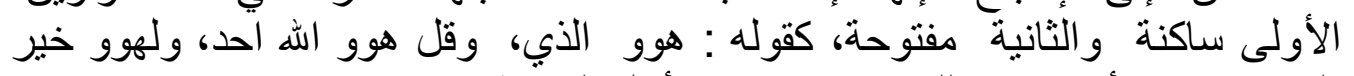
الرازقين، وما أثبهها وذلك غئن جير جائز عند أهل الضبط. 


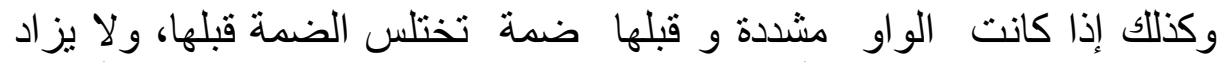

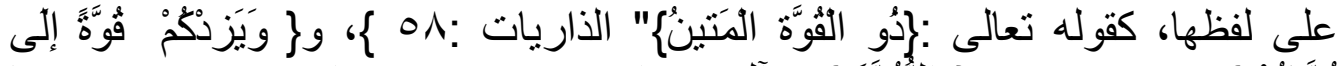

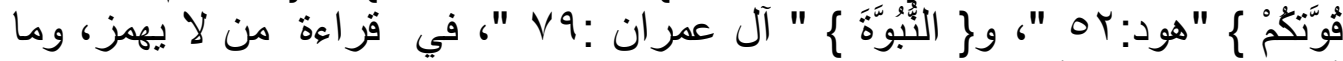

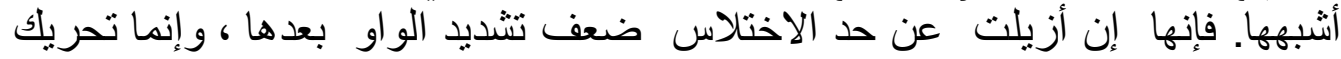

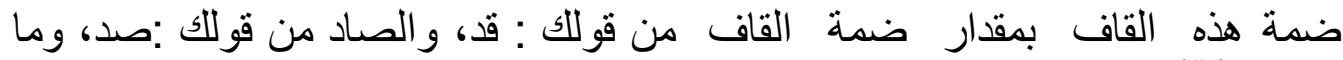

وذكر الداني في كتابه (( التحديد)) مجموعة من الحالات التي يجب على القارئ أن

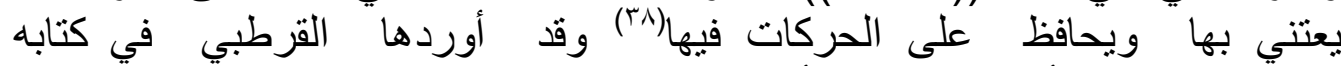

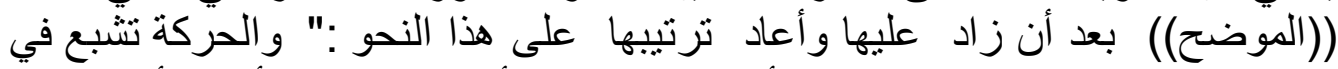

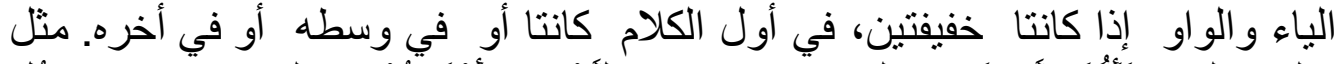

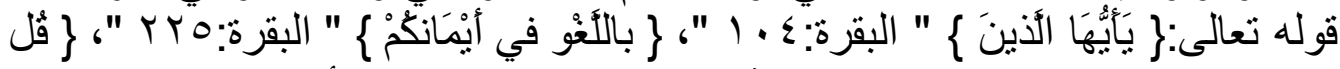

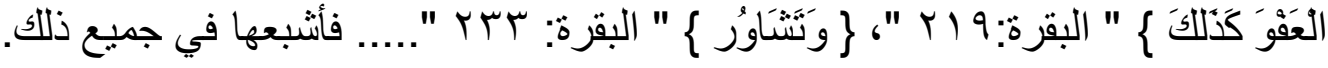

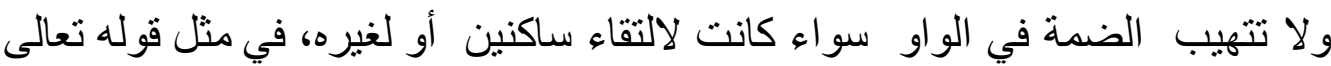

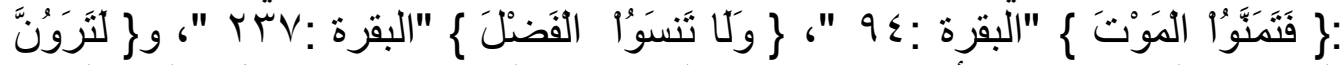

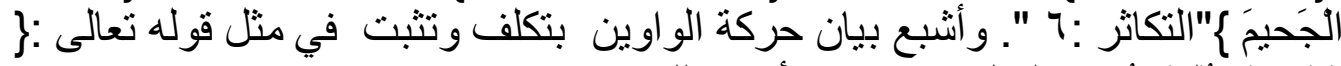

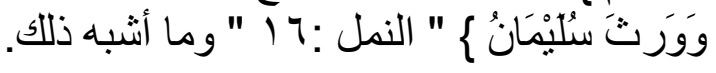

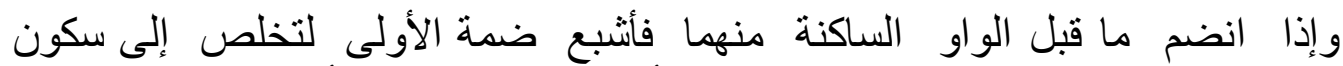

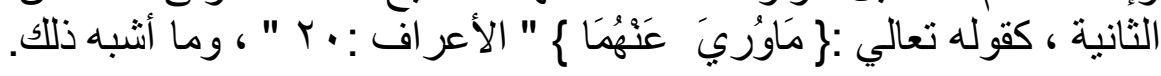

وكذلك أثبع الحركة من غير تنثديد في الياءين و الواوين في مثل قوله تعالي

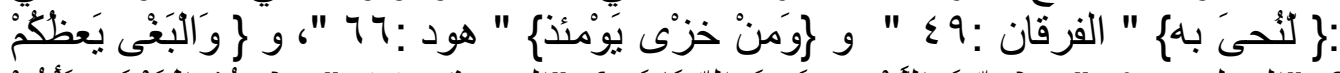

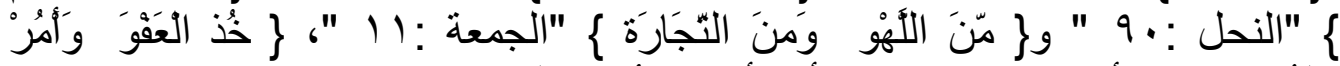

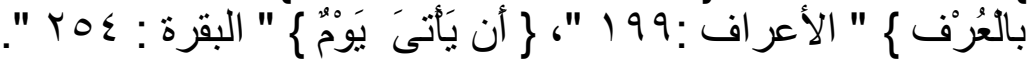

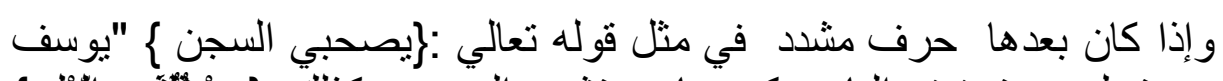

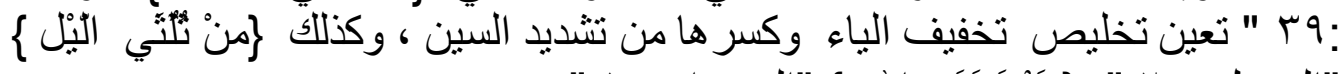

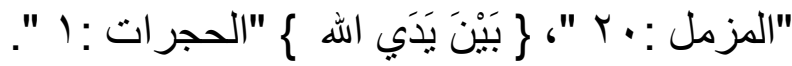

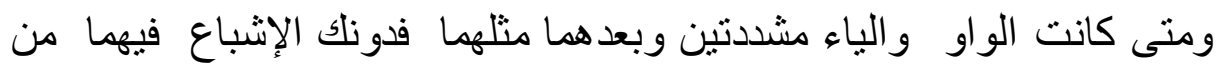

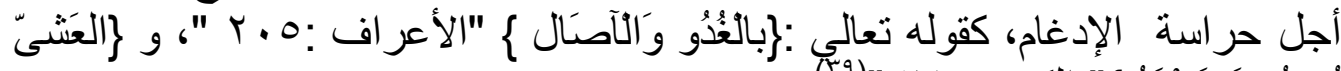

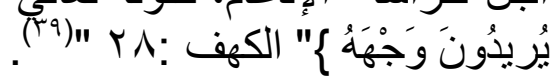




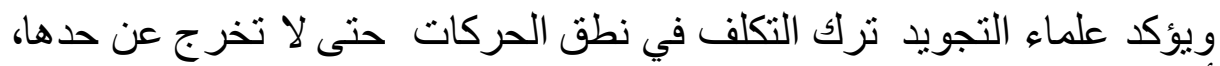

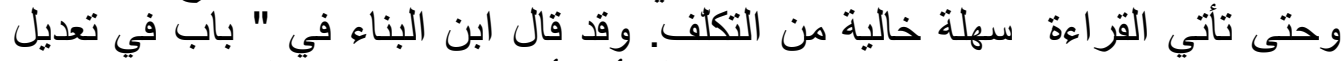

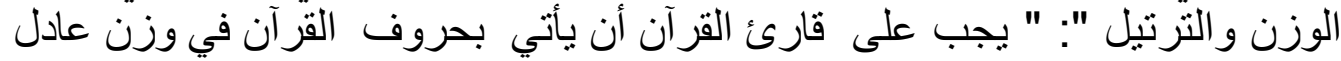

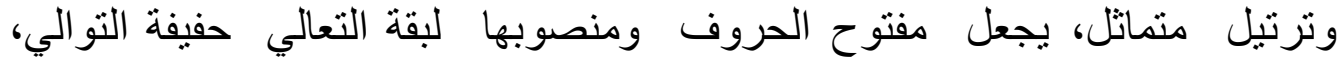

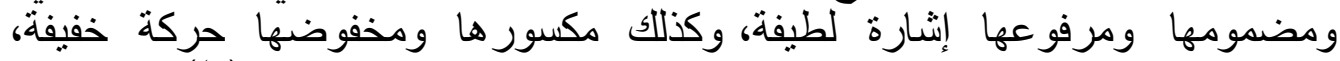

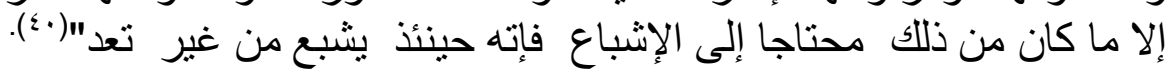

\section{رابعا-الحركات العربية عند المحدثين :-}

لقد اهتم المحدثون في دراستهم اللغوية بالصوائت فالحركات\{، ولكنهم لم يجددوا

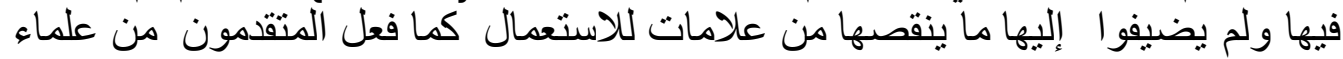

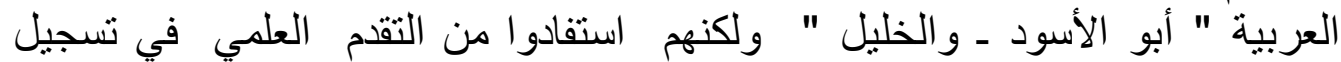

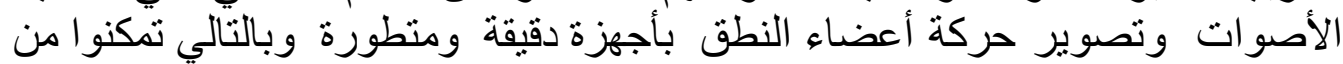

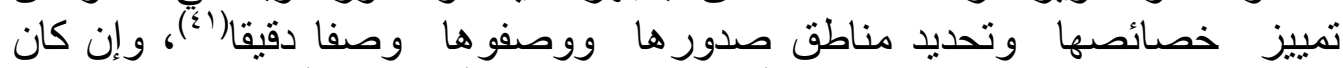

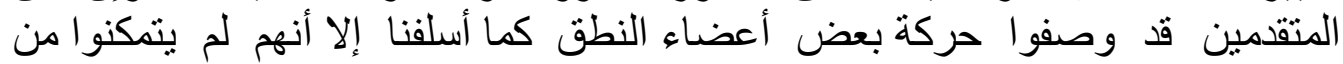

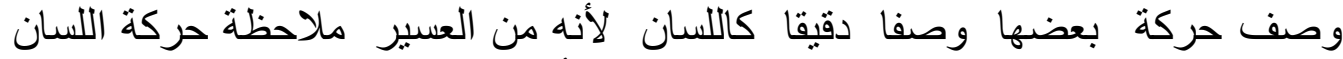

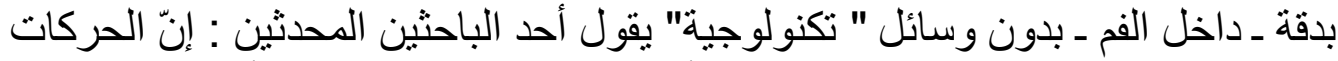

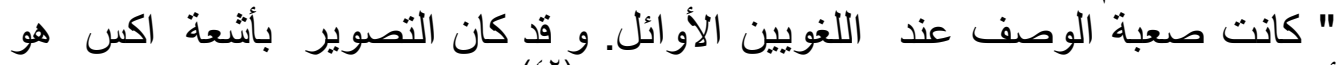

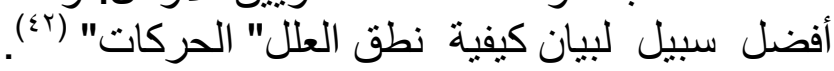

\section{وقد كان اهتمامهم بالحركات للأسباب الآتية : .}

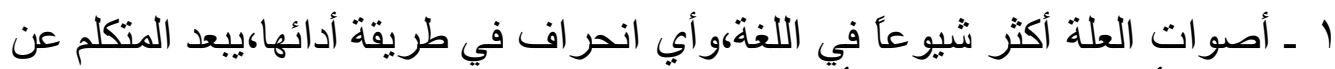

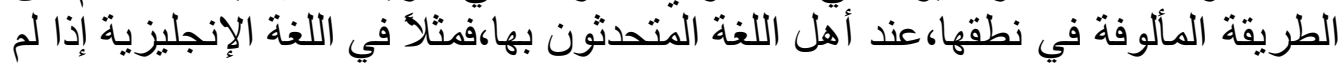

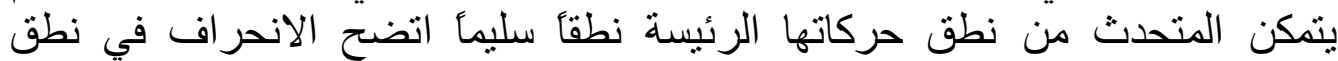

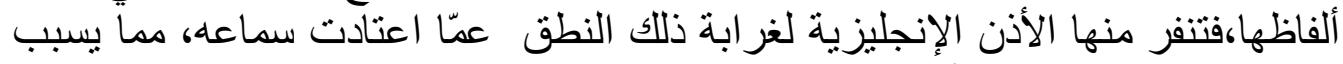

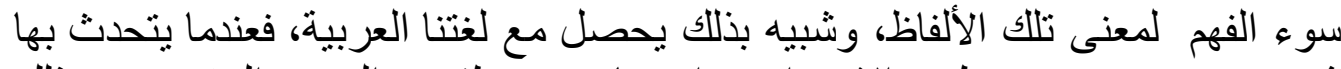

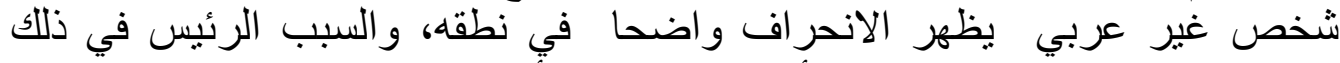

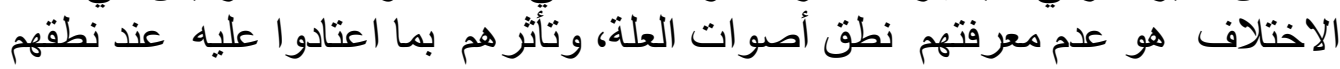
لها في لغتهم.

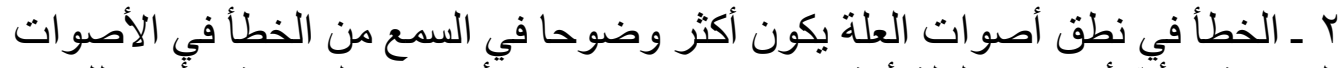

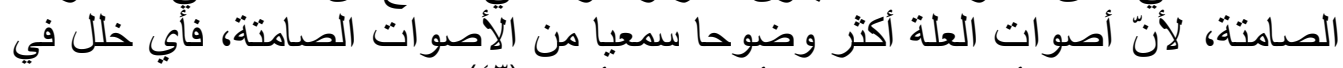

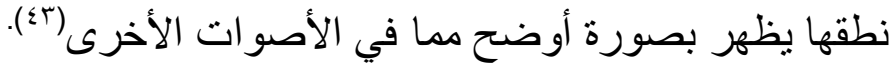


ب ـ الحركات أصعب في النطق من الأصوات الصامتة، وإذا كانت الحركات الأساسية

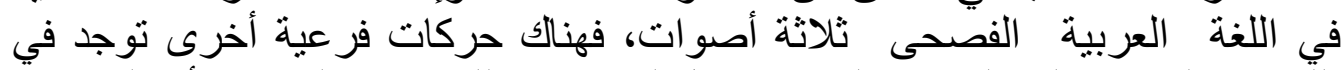

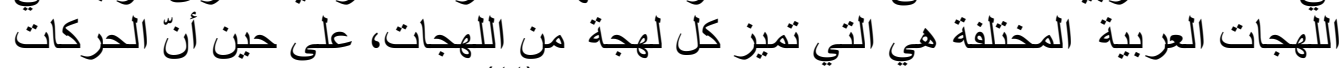

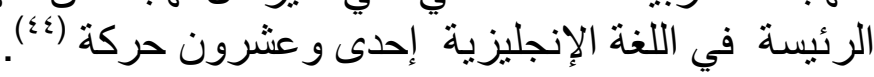

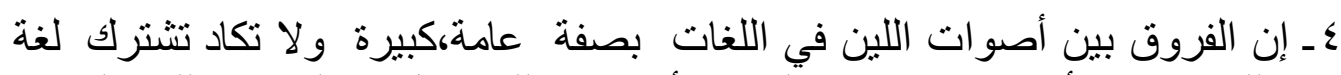

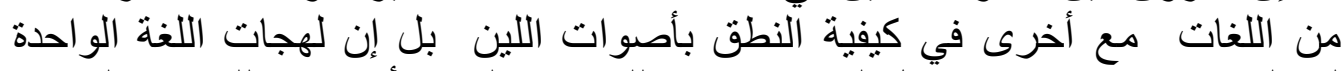

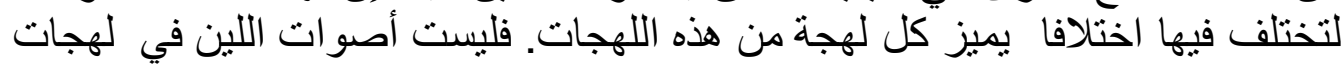

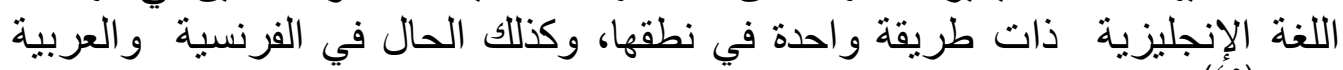

و هكذا(

\section{خامساتتريف الحركات العربية عند المحدثين:-}

لقد عرف اللغويون المحدثون الصوائت بتعريفات متعددة ؛ فعرفها بلوم فيلد

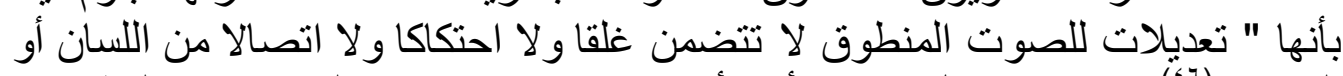

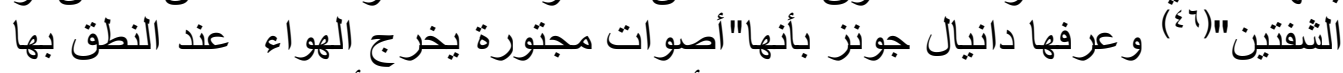

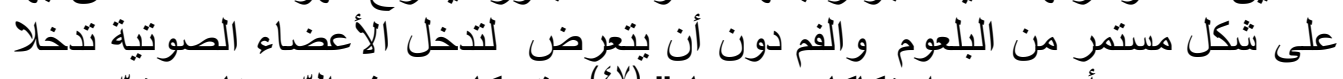

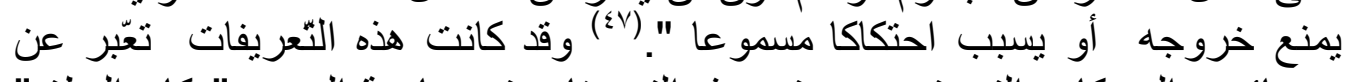

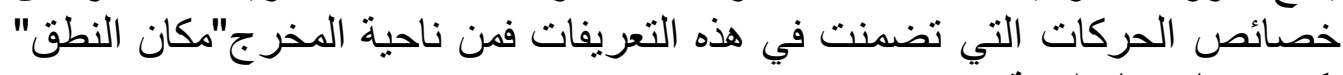
تكون مخار جها و اسعة.

و التُعديلات التي تقوم بها أعضاء النطق في طريق الهواء لا تؤدي إلى إعاقة

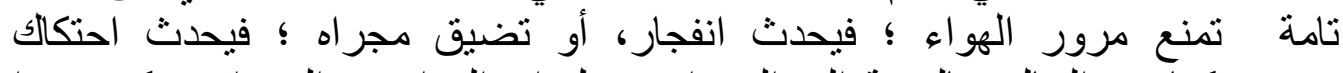

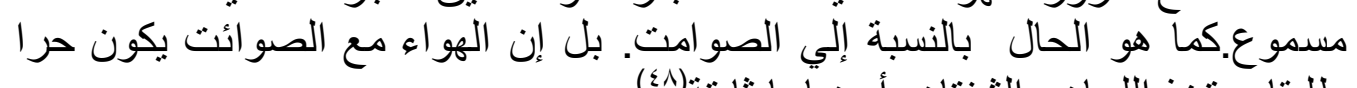

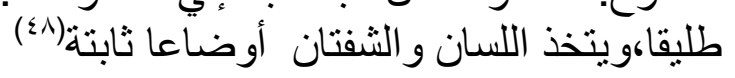

وقد لاحظ المتقدّون من علماء العربية هذه الخاصية بالنسبة إلى الصوائت حيث يقول

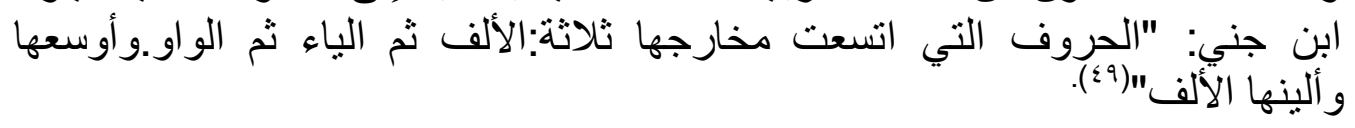

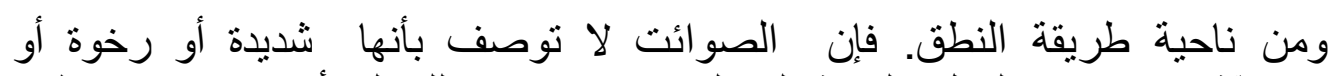

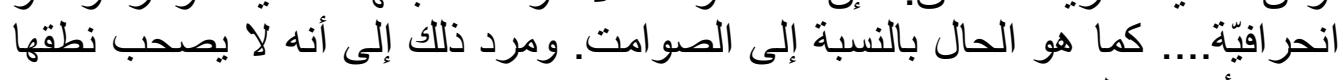
انفجار أو احتكالك مسموع.

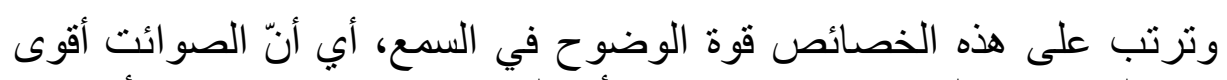

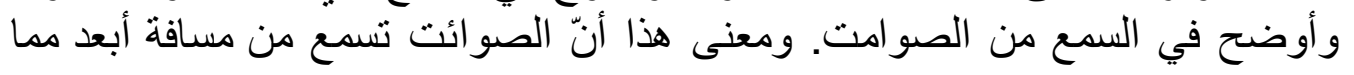




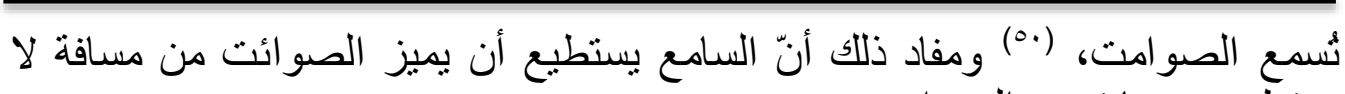
يستطيع عندها تمييز الصوامت (ومغاد.

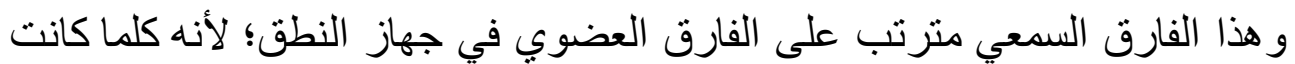

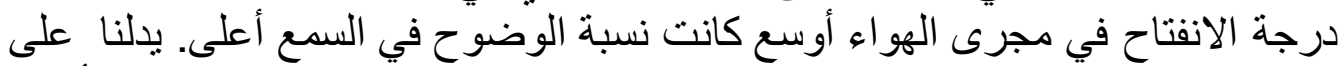

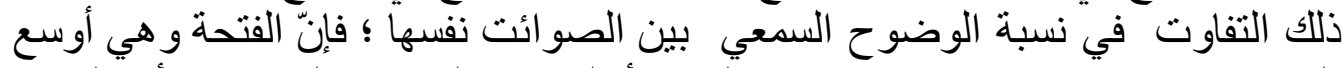

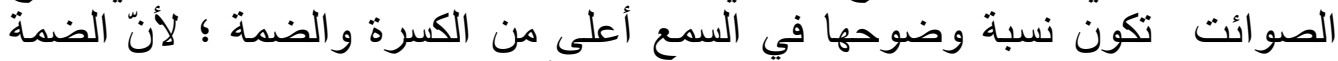
و الكسرة تكون درجة اتساع مجرى اللهو اء معهما أقل منهامع الفتحة.

سادسا- مقاييس أصوات اللين:-

عني المحدثون من علماء الأصوات اللغوية بالبحث في أصوات الإتهي اللين وضبطها

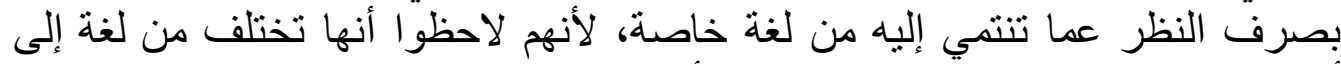

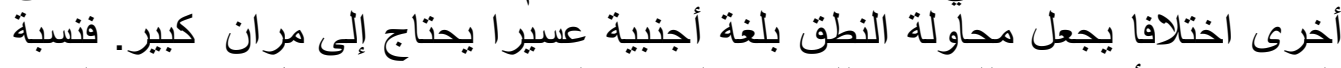

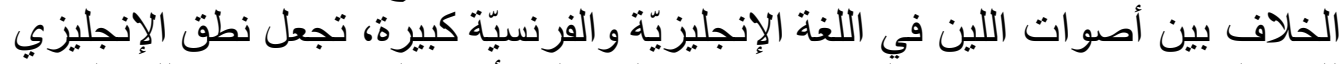
للغة الفرنسية شاقا مشوبا بلهجة غريبة ثقيلة على أذان الفرنسينة الفينين، وكذلك العكس نطي بالعكس.

وأصوات اللين في كل لغة كثيرة الدوران و الثيوع، وأي انحرف عن أصول

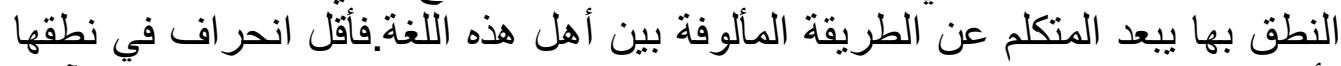
لأصوات اللين في اللغة الإنجليزية، يجعل نطقنا لهذه اللغة غريبا لا تستسيغة الآذان الطيان

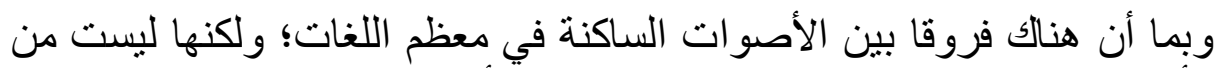

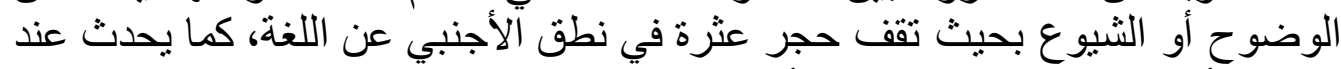

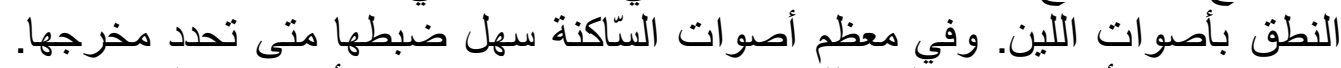

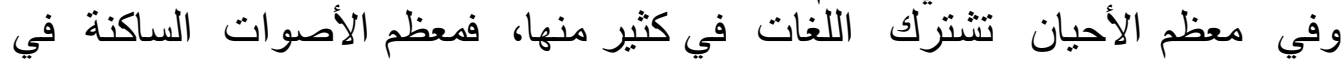
اللغة الفرنسية تماثل إلى حد كبير نظائر ها في اللغة العربية.

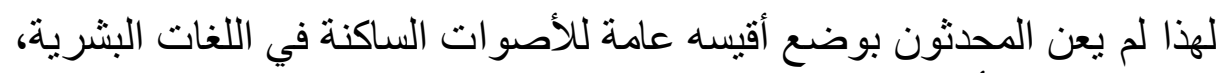

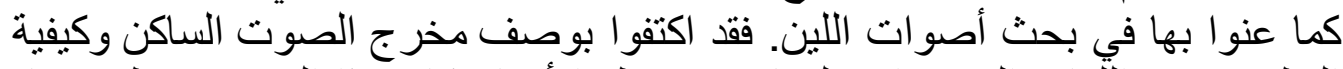

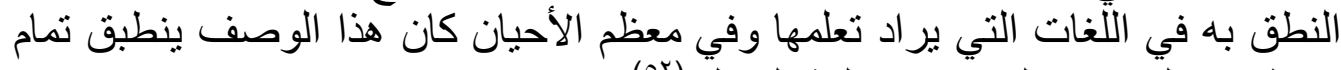
الانطباق على نفس الصوت في لغة المتعلم (ه)

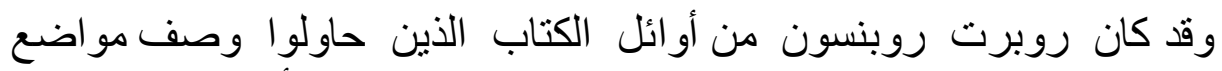
أعضاء النطق خلال نطق العلل. وقد ضمن بحثه رسما توضيحيا للأعضاء المتداخلة. 
ولم تعط دراسة روبرت ما تستحقه من تقدير إلا مؤخرا، حتى لقد عده بعضهم أول عالم أصو اتي حديث روبرث (ro).

وقد أقام روبرت رسمه للعلل الرئيسية في الإنجليزية على موضع اللسان حيث النطق بالعلة ، وهو أساس ما روبز ال مستعملا حتى الآن.

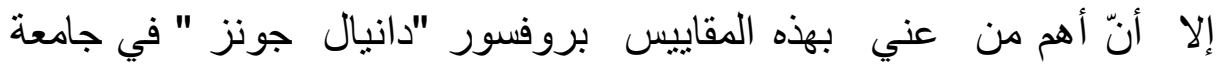

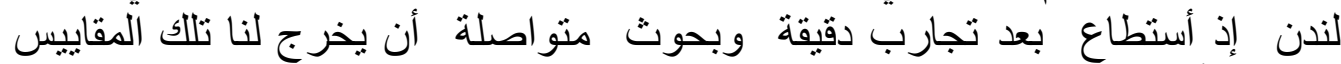

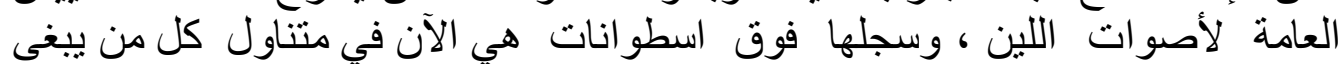
تعلمها (0)

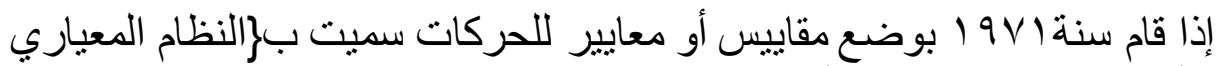

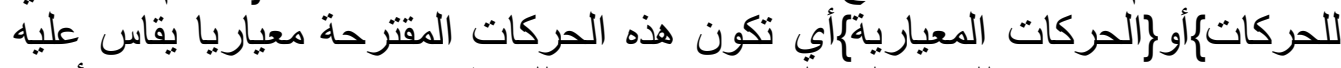

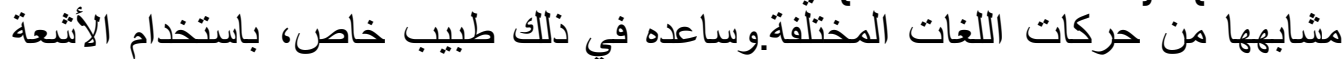

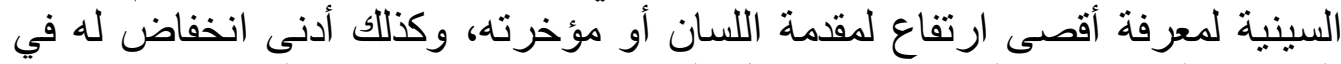

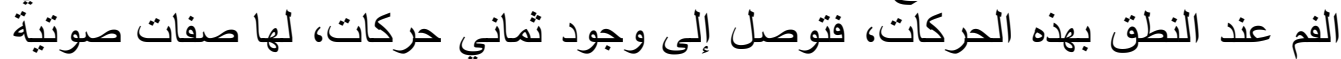

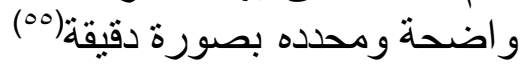

وقد نظر دانيال إلى اللسان في اتجاهين :علوي وسفلي وأمامي وخلفي،فحدد

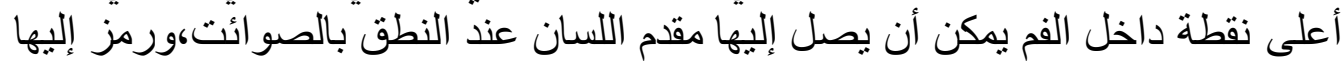
بالرمز(i). وحدد أسفل نقطة يمكن أن يصل إليها مقدم اللسان عند النطق بالصو ائت،

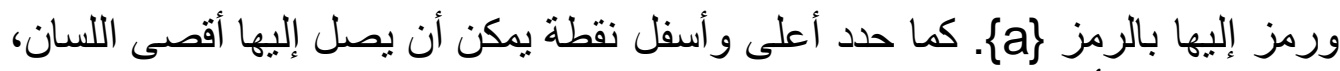

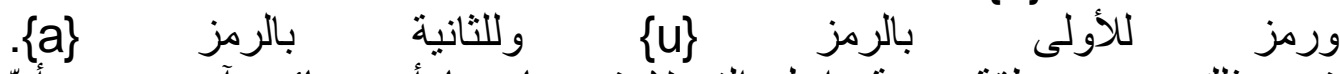

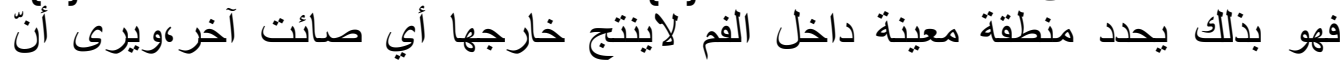

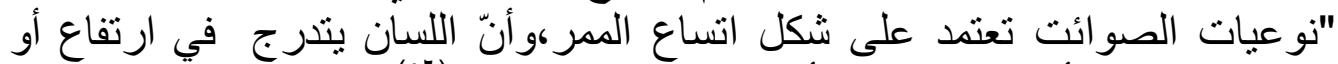

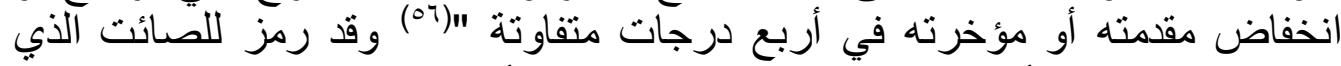

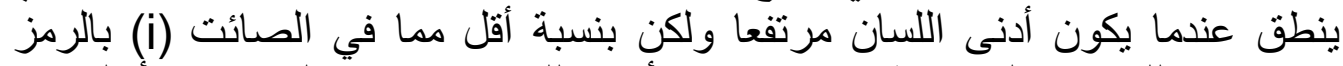

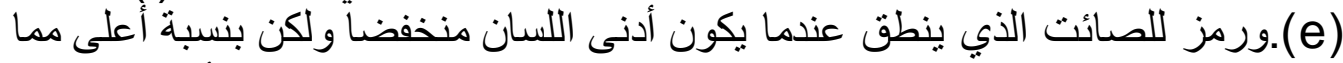

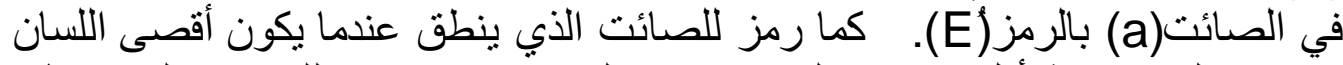

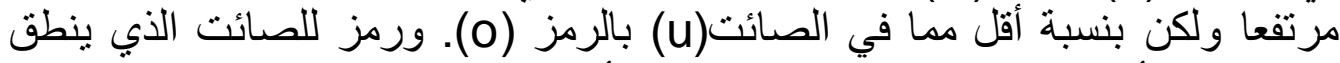

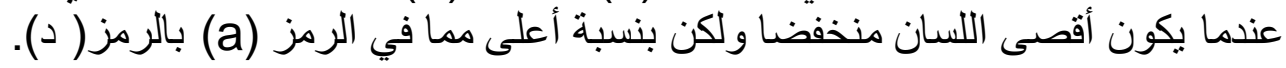
سابعا-الصوائت المعيارية الأساسية عند جونز:- 


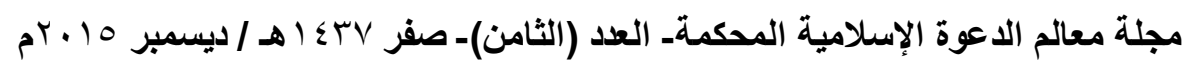

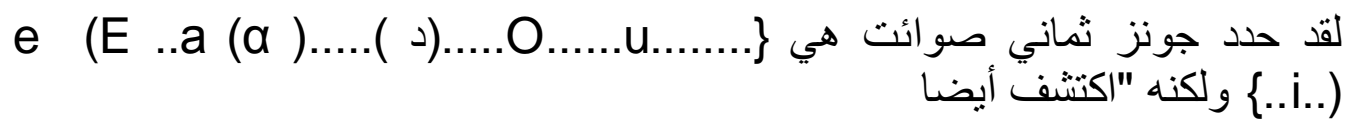

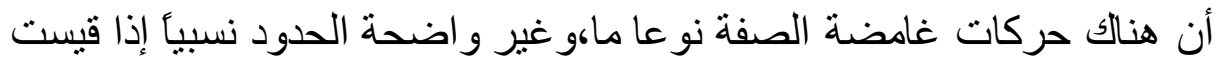

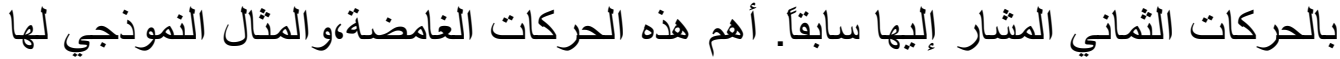

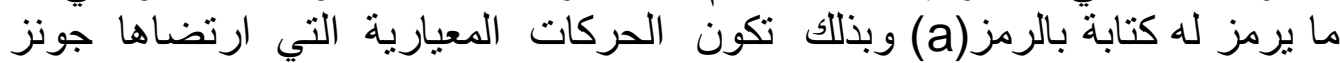

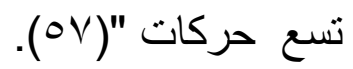

وفي الثكل التالي توضيح للصوائت المعيارية الأساسية وموقعها من اللسان كما

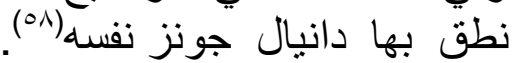

i. ضيق خلفي u نصف ضيق أمامي نصف ضيق نصف منسع أمامي E. نصف منسع خلفي متسع أمامي a. a متسع خلفي

\section{رسم تخطيطي للحركات المعيارية الأساسية}

ويلاحظ من خلال الثكل الموضح أعلى نقطة يمكن أن يصل إليها أدنى اللسان،

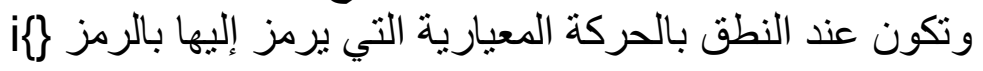

ثمّ يتدرج أدنى اللسان إلى أسفل حيث الحركة e\} ثم إلى الحركة E نقطة يمكن أن يصل إليها أدنى اللسان وتكون عند الحركة a

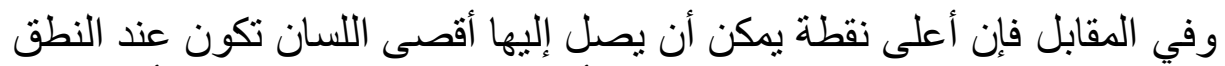

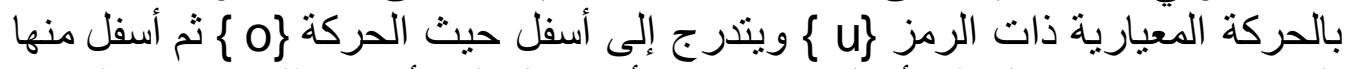

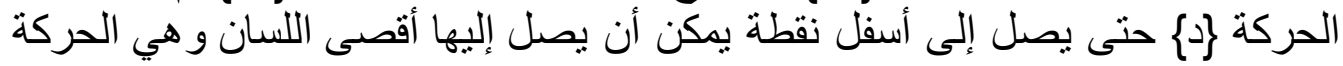

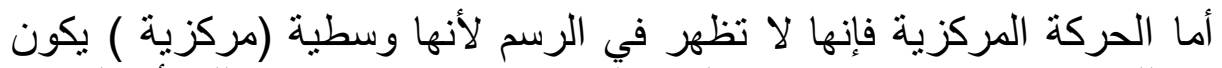

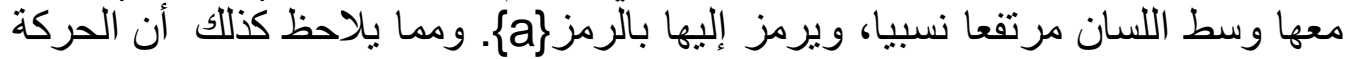
المعيارية الر ابعة a\} a و التي تقابل الفتحة المرققة في العربية ـ يكون موضعها من 


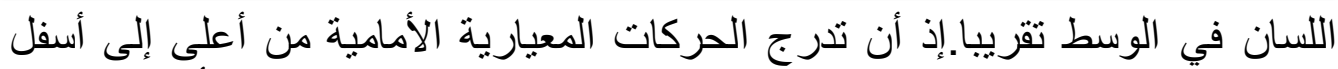

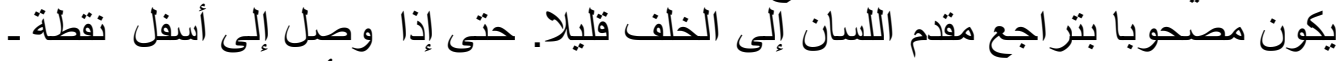

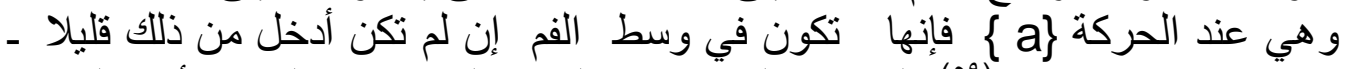

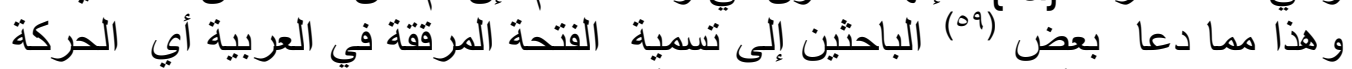

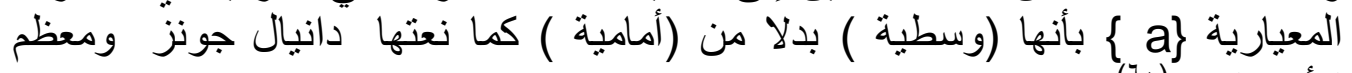
الأصو اتيين(7.)

و هذه الحركات المعيارية الأساسية ليست حركات لغة معينة، ولكنها مقاييس

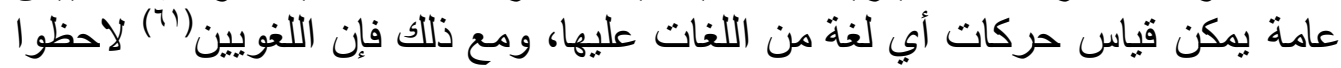

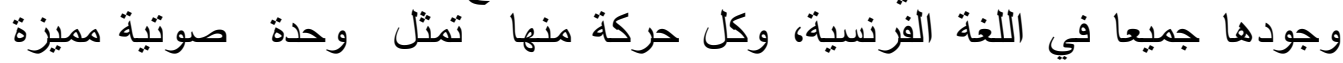

.( phoneme)

\section{ثامنا-الحركات المعيارية الأساسية : -}

إن تصنيف ووصف الحركات يعتمد على المعايير الآتية:-

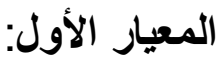

تحديد الجزء المرتفع أو البارز من اللسان، وهذا الجزء قد يكون مقدمة اللسان

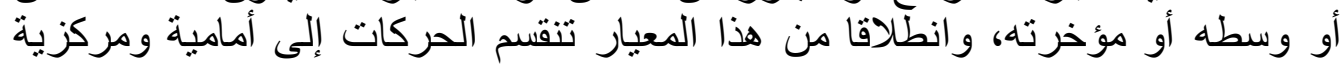

تحديد المسافة التي تفصل الجزء البارز من اللسان من سقف الحنك الأعلى،

$$
\text { و هذه المسافة تنقسم إلى أربعة مسافات فر عية الته }
$$

أـ و اسعة: وتعني أن المسافة بين أعلى نقطة على سطح اللسان وسقف الحنك قد وصلت

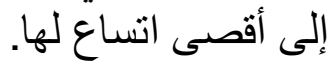

ب ـ ضيّقة: وتعني أن الجزء المرتفع من اللسان قد وصل إلى أقصى مداه من الارتفاع بحيث إذا تجاوز هذا المدى أحدث احتكاكا مسمو عا.

ج - نصف واسعة وتثير إلى وصول اللسان إلى مستوى أعلى قليلا مما كان عليه في حالة الحركة الو اسعة. 
د ـ نصف ضيقة وتثير إلى أن نقطة ارتفاع اللسان لم تصل إلى أقصى درجة من الارتفاع و إنما وصل إلى نقطة دونها بقليل.

\section{المعيار الثالث:-}

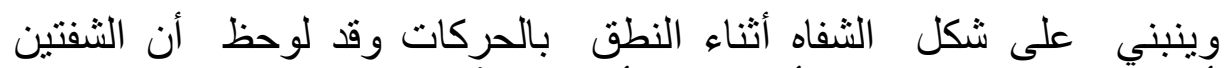

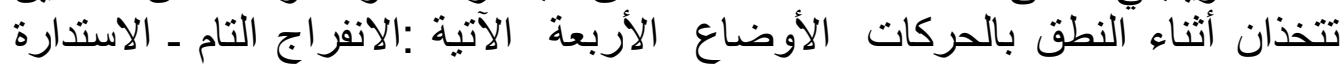

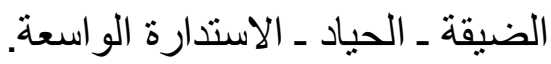

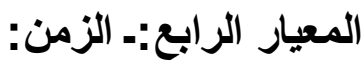

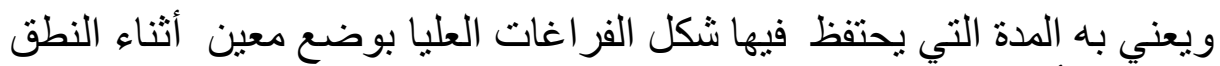

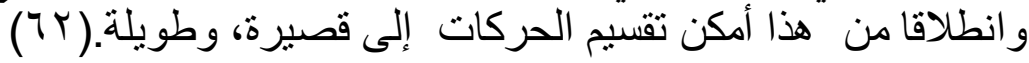

\section{أولا:مجموعة الصوائت الأمامية:}

وسميت أمامية لأنها تنسب إلى الجزء الأمامي من اللسان. وتوصف جميع هذه الصوائت بأنها غير مدورة، لأن الثفتين لا تستديران حال النطق بها. ورهذ النهان الصوائت هي :- الصوانت

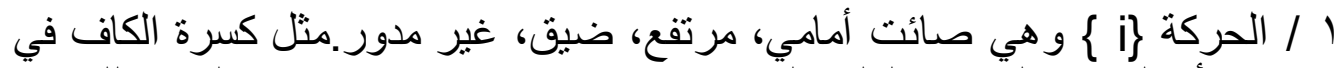

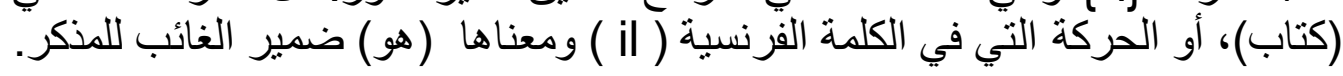

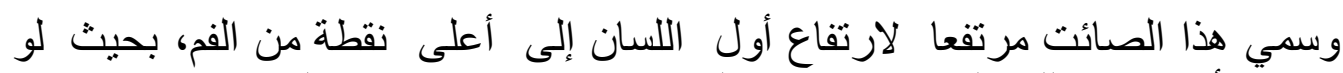

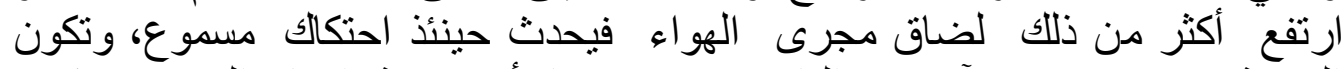

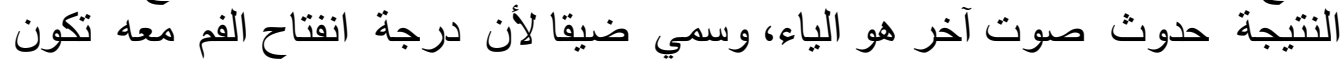

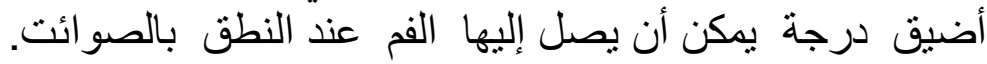

r /الحركة (e) و هي صائت أمامي، منوسط الارتفاع، نصف ضيق، غير مدور .ومثاله

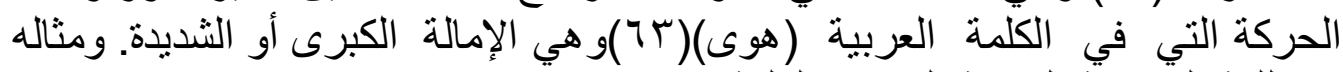

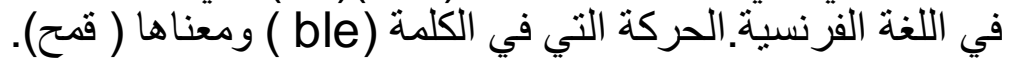

وسمي هذا الصائت متوسط الارتفاع لارتفاع اللسان إلى نقطة هي أقل ارتفاعا

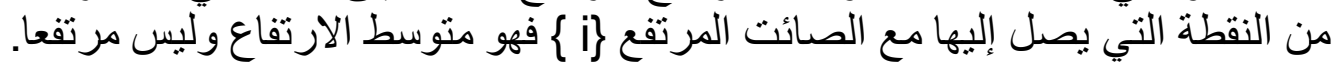
وسمي نصف ضيق لأن درجة انفتاح الفم معه تكون أوسع قليلا مما في الصائت الضيق \} \{ فهو نصف ضيق وليس ضيقا. 


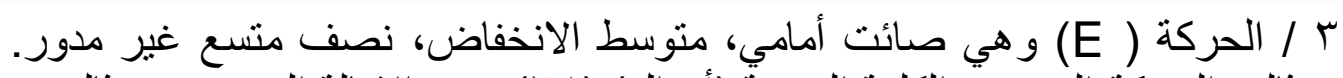

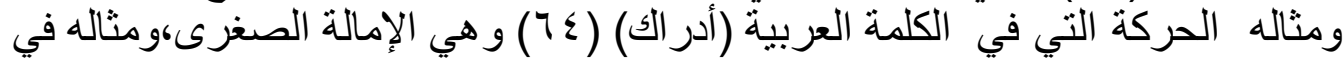

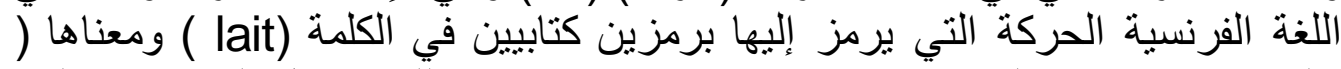

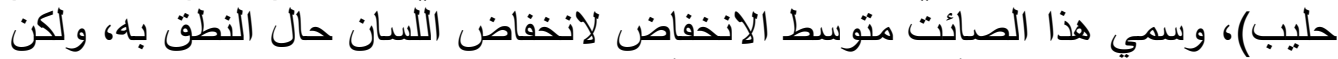

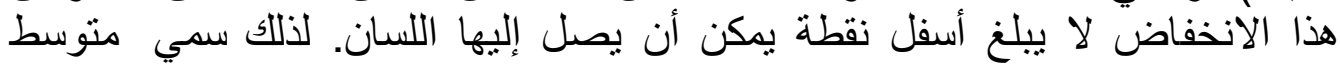
الانخفاض.

وسمي نصف متسع لأن درجة انفتاح الفم معه تكون أوسع منها مع الحركتين السابقتين \}í ع الحركة a\} و هي صائت أمامي، منخفض، متسع، غير مدور. ومثاله فتحة التاء

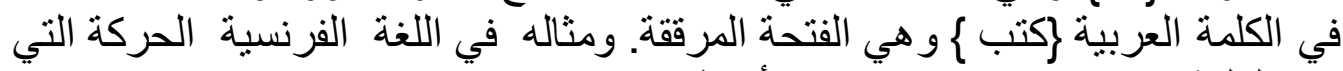
في الكلمة

وسمي هذا الصائت منخفضا لانخفاض اللسان حال النطق به حتى يبلغ أسفل نقطة يمكن أن يصل إليها اللسان في قاع الفه.

وسمي متسعا لأن درجة انفتاح الفم معه تكون أوسع درجة يمكن أن بيلغها الفم

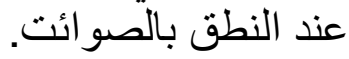

\section{ثانيا :مجموعة الصوائت الخلقية:-}

وسميت خلفية لأنها تنسب إلى الجزء الخلفي من اللسان، فهو الجزء الجهاء المتحرك

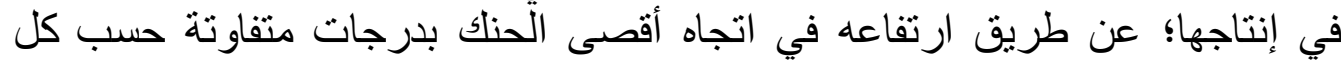

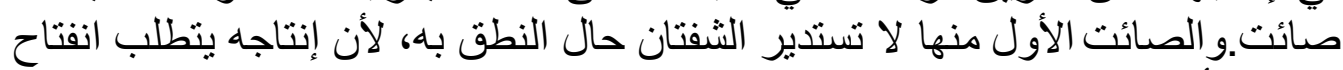

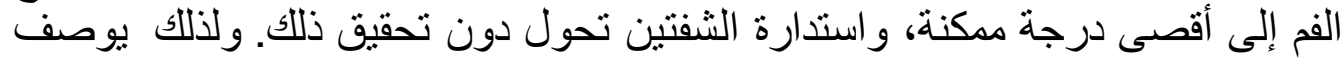

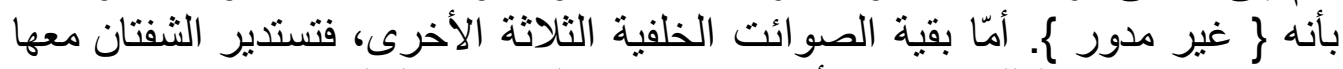

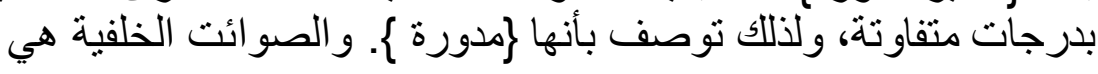

/ / الحركة a

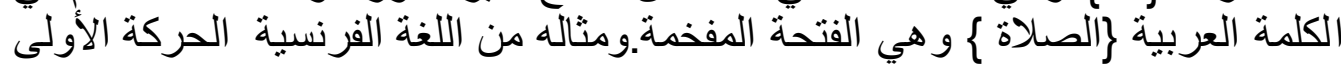
التي في الكلمة pabe

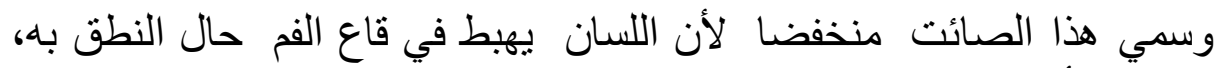

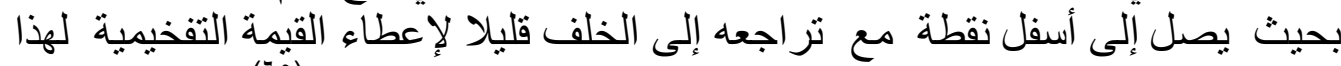

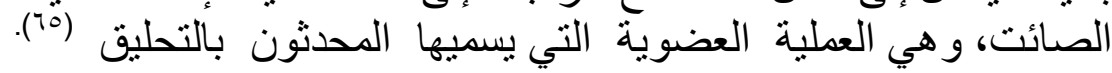




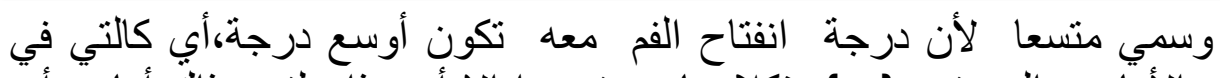

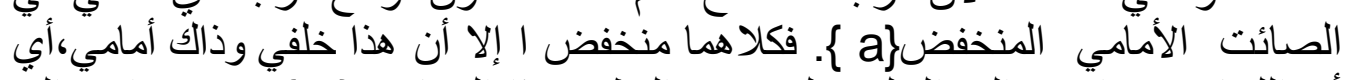

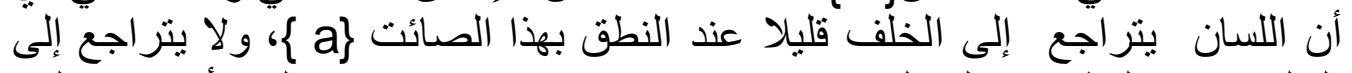

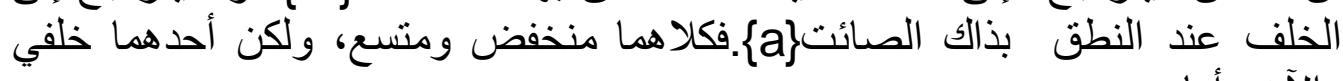
و الآخر أمامي.

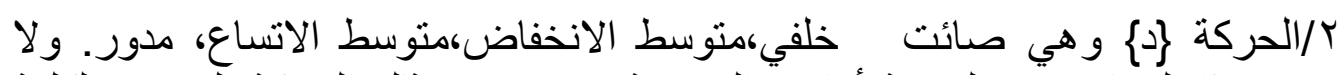

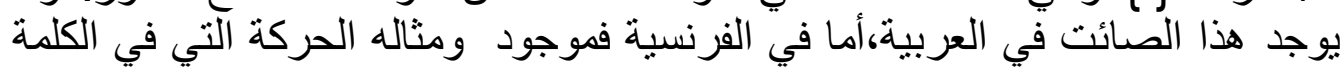

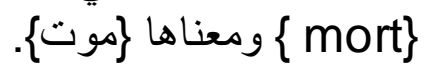

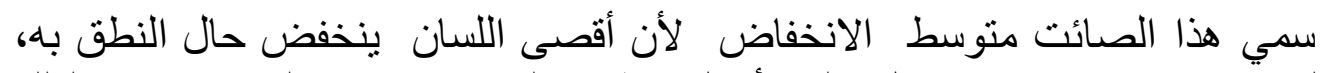

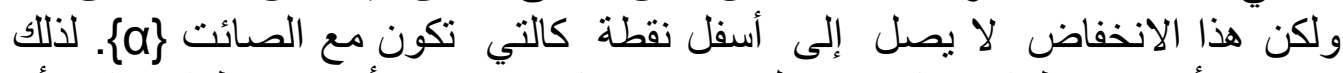

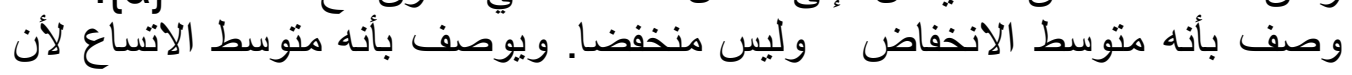

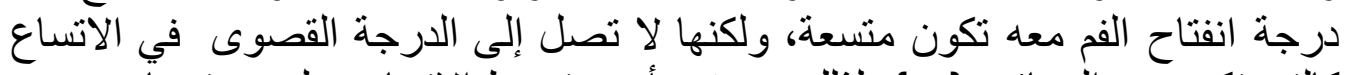
كالتي تكون مع الصائت

ب / الحركة \}0 \{ و هي صائت خلفي،متوسط الارتفاع،نصف ضيق،مدور ـ و لا يوجد هذا

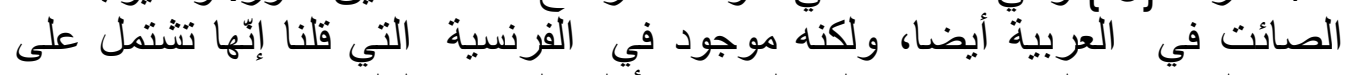

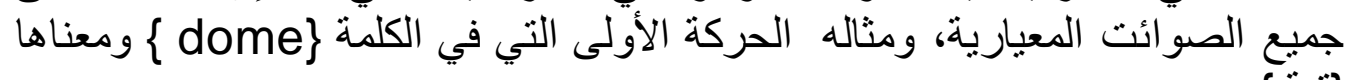
$\{$ جنبع

وصف هذا الصائت بأنه متوسط الارتفاع لأن أقصى اللسان يكون مرتفعا

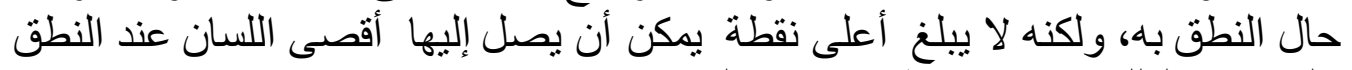

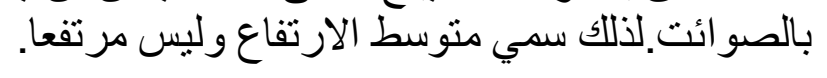

ووصف كذلك بأنه نصف ضيق،لأن درجة انفتاح الفم معه تكون ضبقة،هولكنها

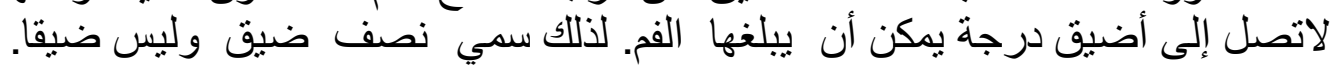
ع / الحركة U\} و و هي صائت خلفي، مرتفع، ضيق، مدور .ومثاله في العربية الضمة

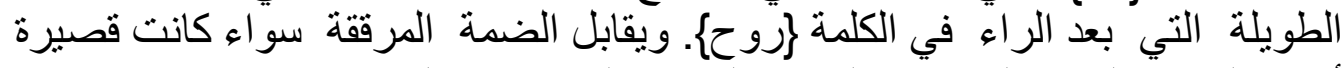

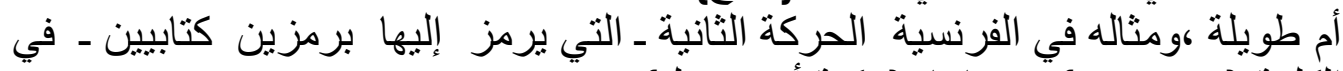
الكلمة

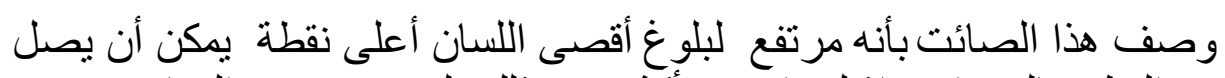

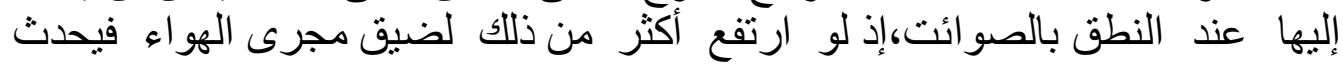


حينئذ احتكالك مسموع، وتكون النتيجة حدوث صوت آخر \}ليس من الصوائت\{وهو الو او (77).

ووصف كذلك بأنه ضيق لأن درجة انفتاح الفم معه تكون أضبق درجة بمكن

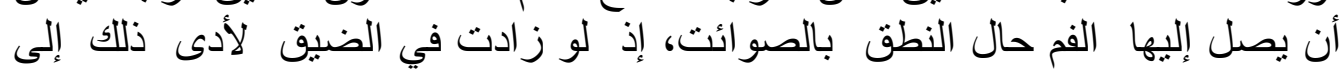
تضييث مجرى الهواء. فيحدث احتكالك مسموع، وتكون النتيجة حدوث

أما الحركة المركزية \} a

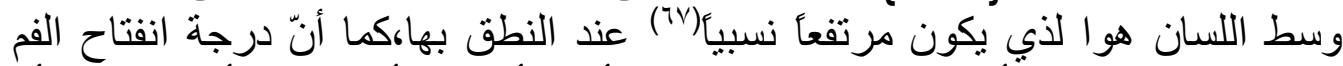

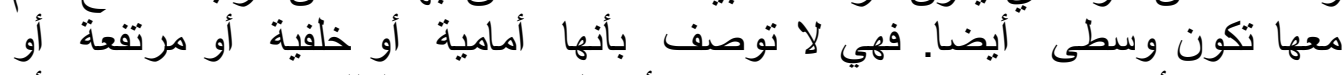

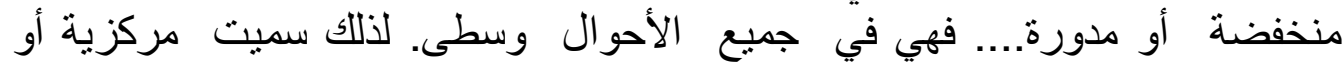
وسطى. منخط.

و هذه الحركة موجودة في العربية، ومن أمثلتها تلك الحركة الخفيفة التي تلحق أصوات

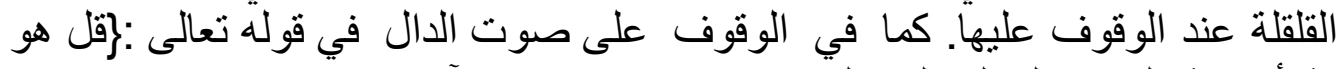

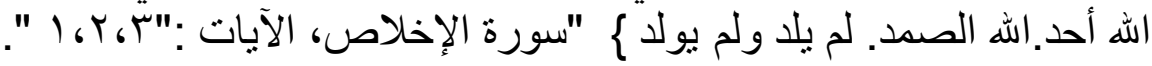

ومثالها في اللغة الفرنسية الحركة الأولى التي في الكلمة

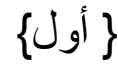

\section{تاسعا-الحركات المعيارية الثواني :-}

إذا ما قارنا بين الصوائت الأمامية و والخلفية ـ في الحركات المعيارية

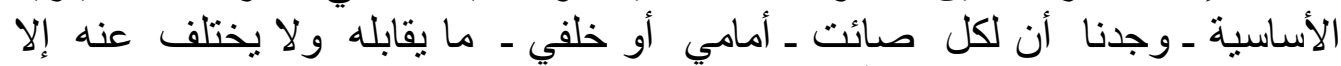
في صفة واحدة ؛ فالصائت الأمامي

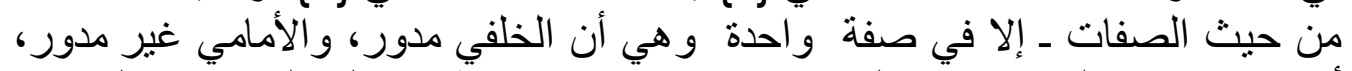

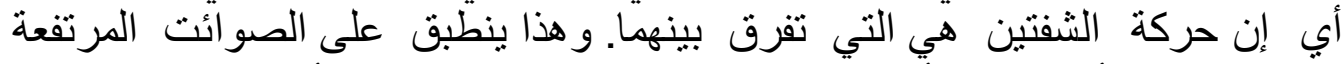
والمتوسطة الأخرى \} الأمامي الخلفي

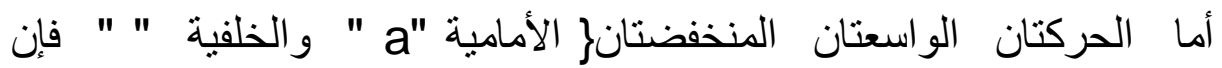

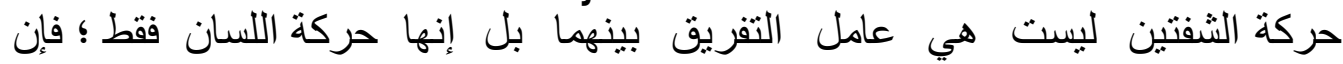

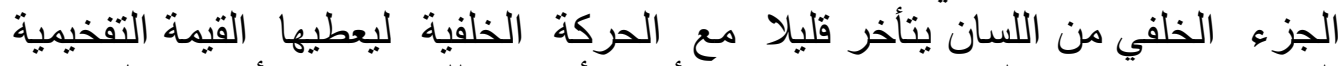
التي تتميز بها في السمع في حين لا يتأخر أقصى اللسان مع الأمامية، بل يكون 
منبسطا في قاع الفم، فتبقى الحركة مرققة ؛ فالفرق بينهما هو التفخيم والترقيق،

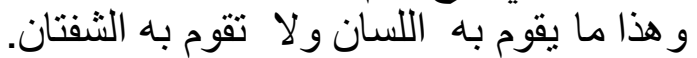

وقد لاحظ اللغويون أن الناطق إذا نطق بالحركات المعيارية الأساسية التي

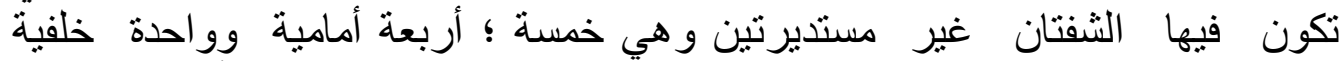
و a.a،E،e،i\}

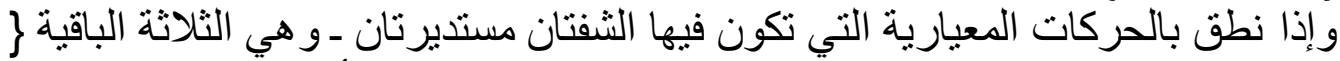

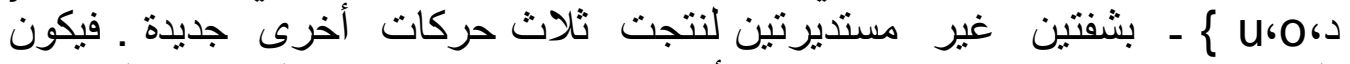

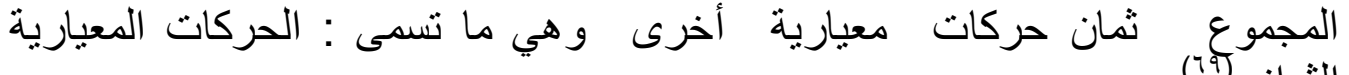
التو انيوع (79).

وقد لاحظ المتقدمون من علماء العربية أن هناك حركات نظهر نتيجة لمزج بين

خصائص الحركات الأساسية وصفاتها.

بذكر ابن جني أن " ما في أبدي الناس في ظاهر الأمر فتلاث. و هي: الضمة

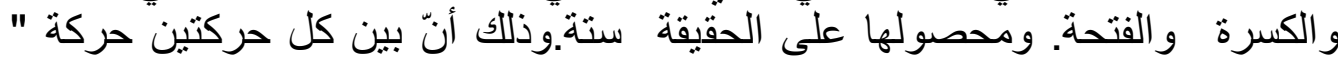
و \{

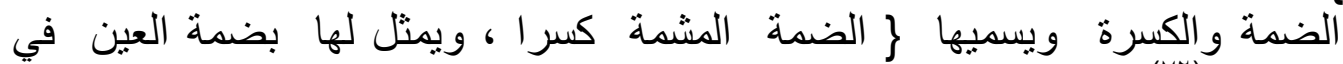
"مذعور" (VY) هي حركة خلفية تنطق بدون استذارة الثفتين.

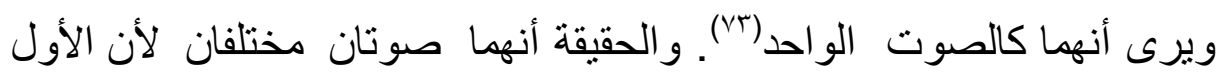

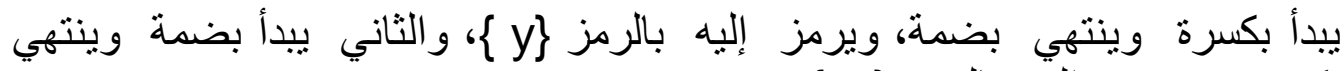

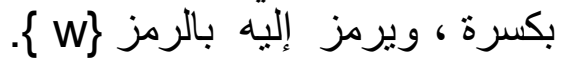

ويرى ابن جني أيضا أنه " ليس في كلامهم ضمة مشربة فئة فتحة ، ولا كسرة

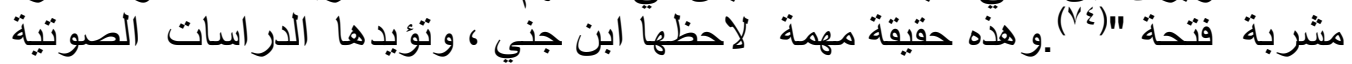

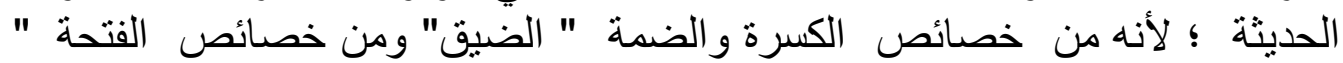

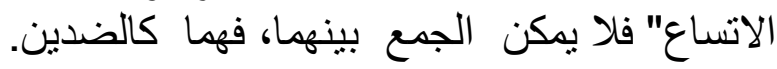

عاشرا-الحركات العربية على ضوء الدرس الصوتي الحديث :-

تتخذ اللغة العربية الفصيحة ثناث حركات فقط تختلف في الطول والقصر ، وتسمى والفي

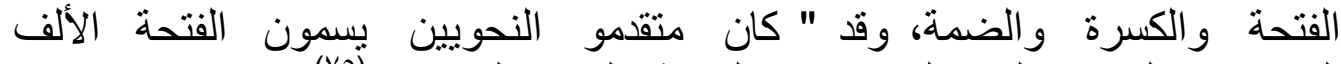

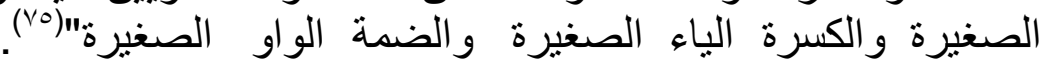




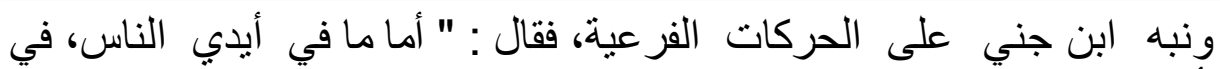

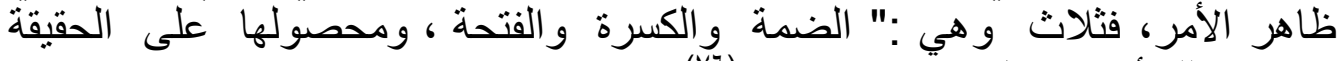

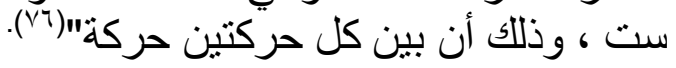

و هذه الأصوات الفرعية التي أثنار إلبها ابن جني هي أصوات ثانوية موجودة

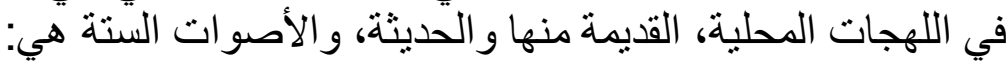

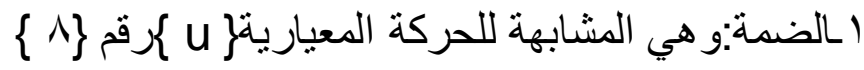
Y rالكسرة:و هي المشابهة للحركة المعيارية\} i rالقتحة:وهي المرققة المشابهة للحركة المعياريّةقa\} رقم\}؛

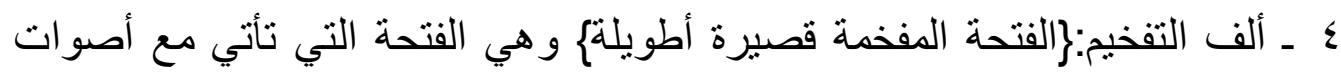
الإطباق\}

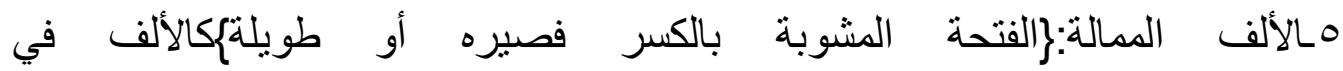
قر اءةرمرساها\{بالإمالة.وتشبه الحركة المعيارية

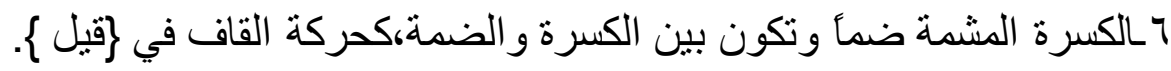
ويضاف إليها الضمة الممالة نحو الكسر،ور عند نطقها نبدأ بنطق الضمة ثم نتنقل

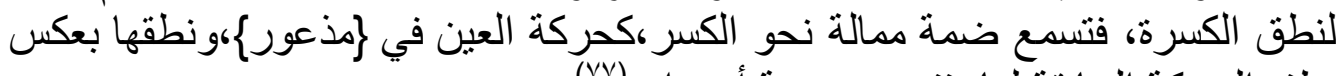

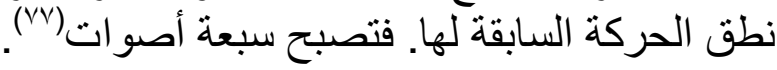

ويتحدد نطق الحركات بحركة مقدة اللسان أومؤخرته نحو سقف الحنك(ㅅ) كما في الثكل التالي(va)

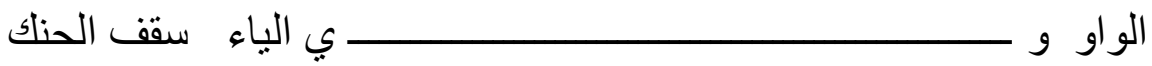<smiles>[AlH2][AlH2][IH][SiH2][SiH2][SiH3]</smiles>
e الضمة الممالة a Q الفتحة المفخمة حادي عشر-وصف الحركات العربية :- 
الفتحة: a

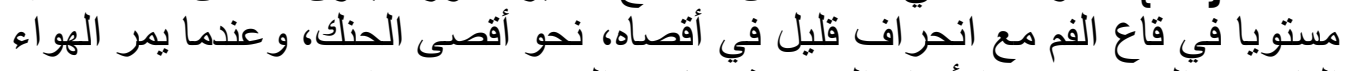

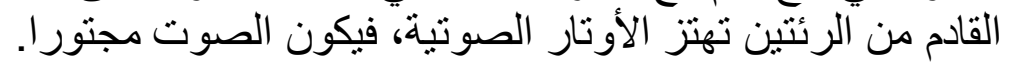

الكسرة : أل :

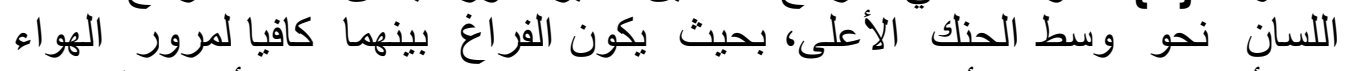

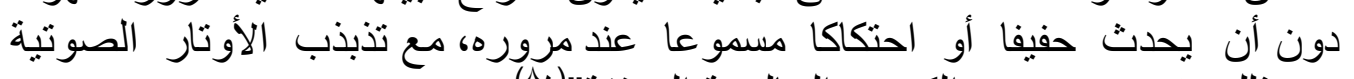

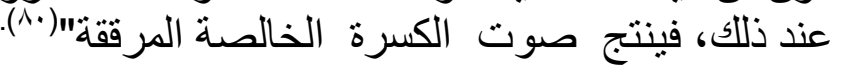

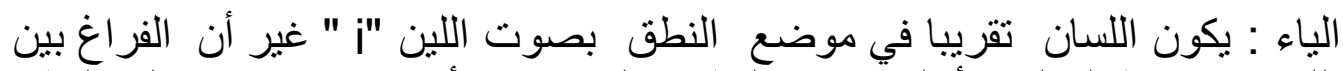

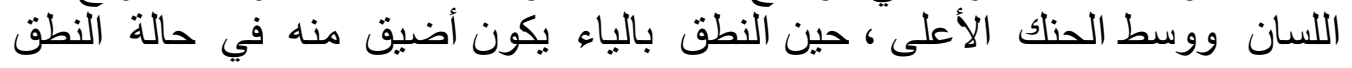

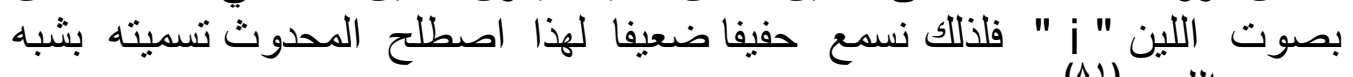
صوت اللين (1) تصوت (e): الكسرة الممالة صوت أمامي،منتوسط الارتفاع،نصف ضيق، غير مدور، عند نطقه تكون مقدمة

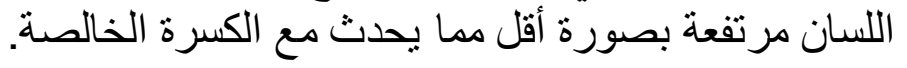

(u): الضمة

صوت خلفي،مرتفع،ضيق،مدور عند نطقه يرتفع مؤخر اللسان نحو سقف الحنك ارتفاعا لا يسبب أي نوع من الحفيف.

(0): الضمة الممالة)

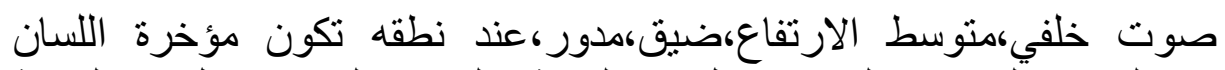

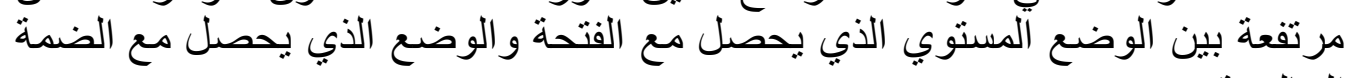
الخالصة.

\section{ثاني عشر-مشكلات الحركات في القديم والحديث:}

لعلّ من أبرز تلك المشكلات كما يقرر الدكتور كمال بشر هي أنّ القدماء بالرغم

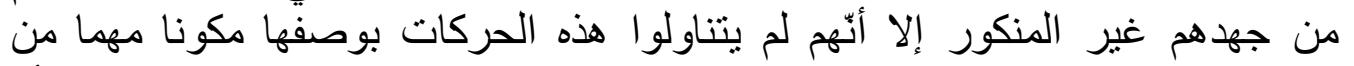

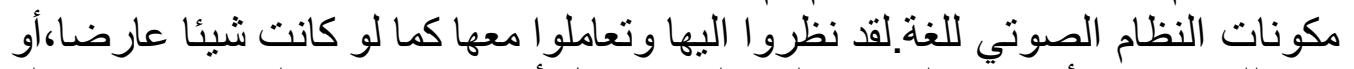

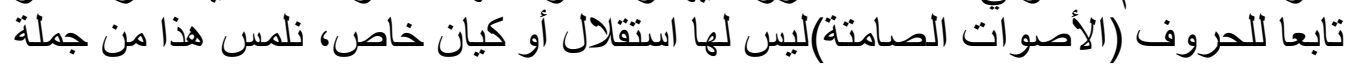


ما صنعوا معها،بل عدّها بعضهج( زوائد)،ليست أصلا في بناء الكلمة.يقول إمامهر

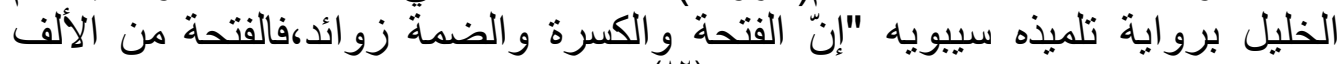
و الكسرة من من الياء و الضمة من الواو " (AT).

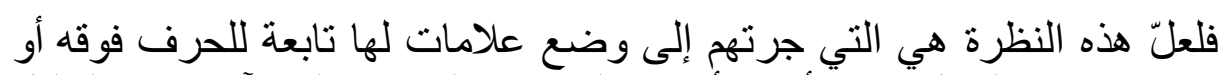

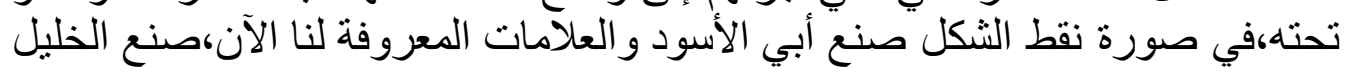

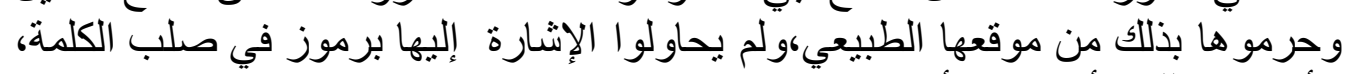
شأنها في ذلك شأن بقية الأصوات.

وجرت الأمور على ذلك حتى يومنا هذا.وكانت ما عانته وتعانيه الأجيال

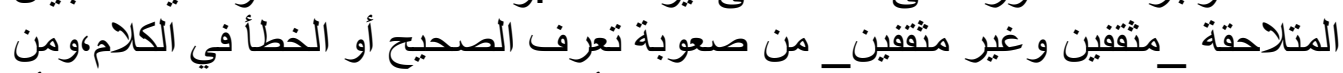

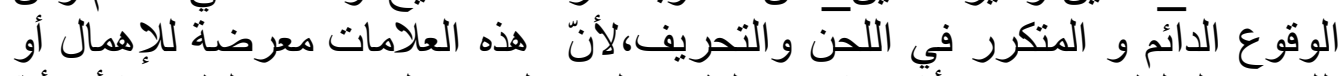

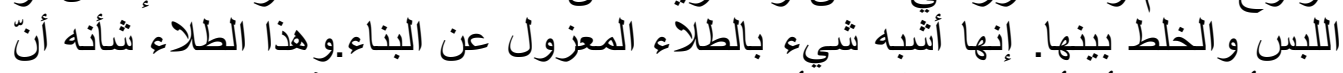

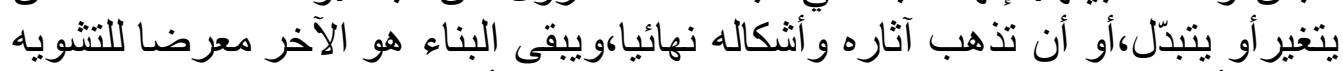

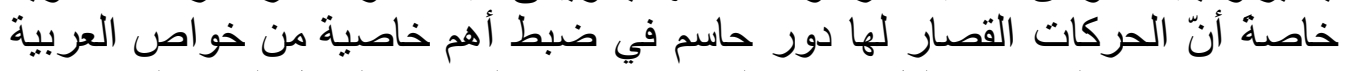

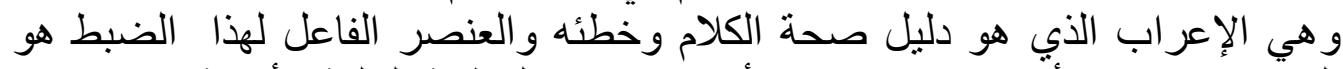

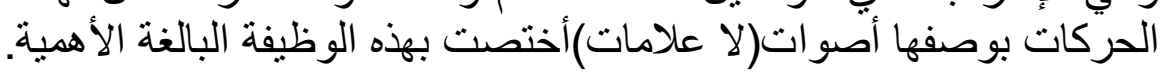

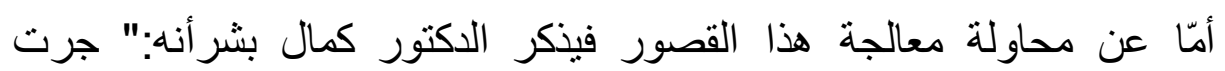

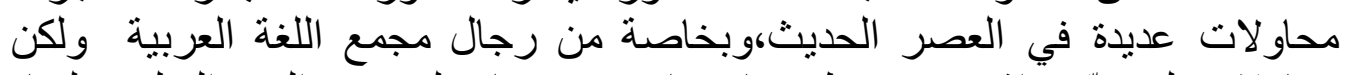

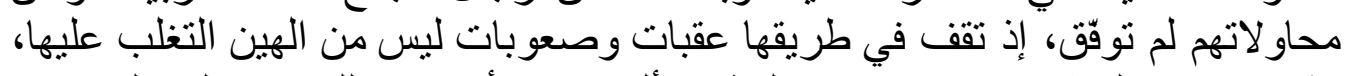

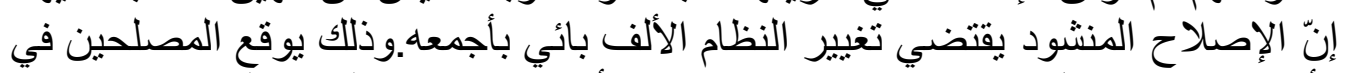

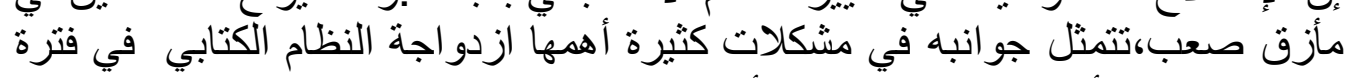

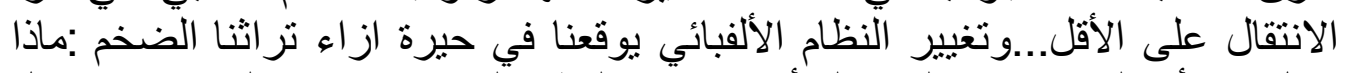

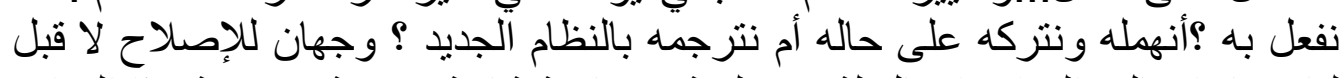

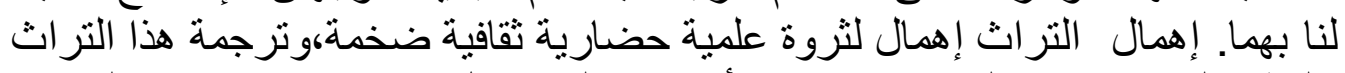

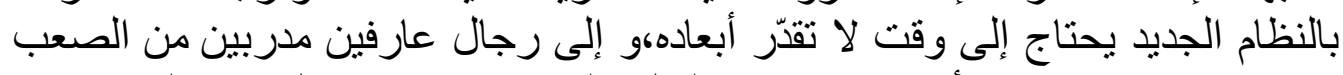

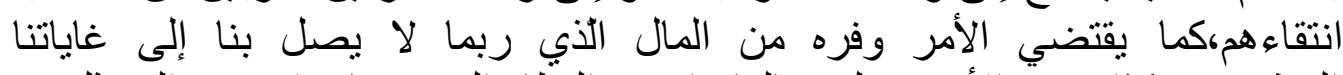

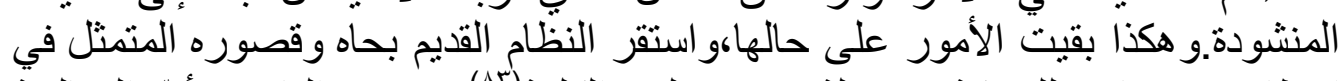

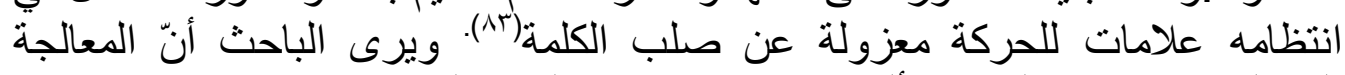

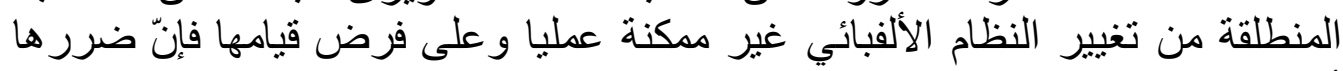

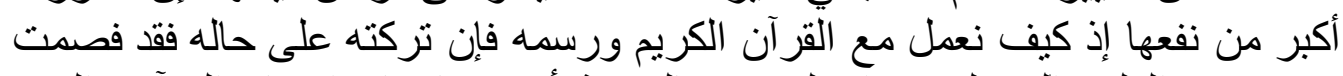

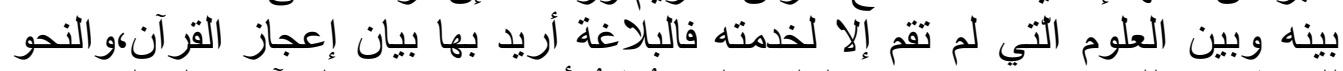

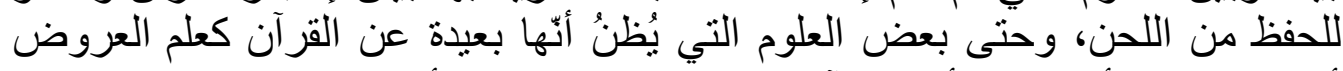

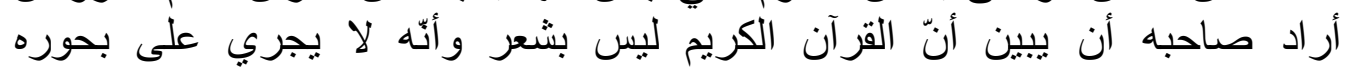


و أعاريضه.فكما ضبط أهل الأداء القرآن الكريم فعلى اللغويون أن بحذو حذو هم في ني

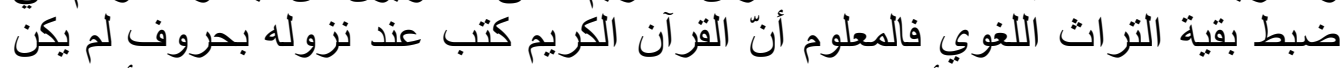

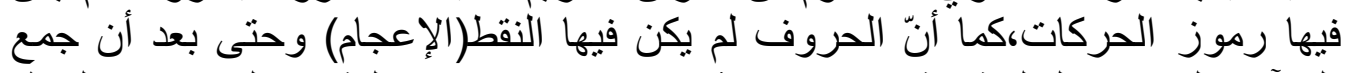

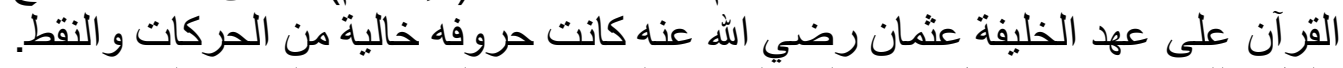

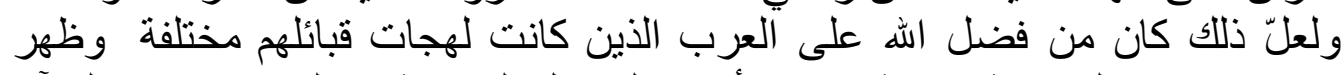

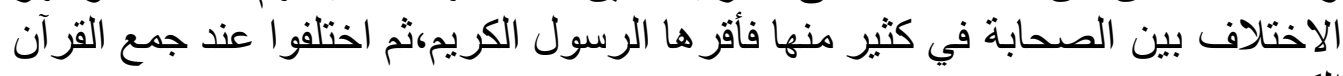
الكريץ.

وفضل الله ظهر في المصحف الإمام الذي كتب (غير مشكول وغير منطوق)

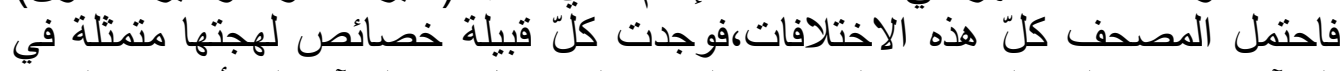

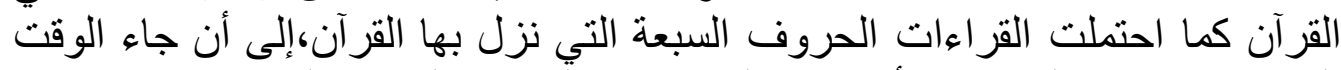

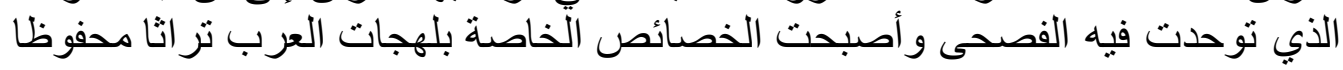

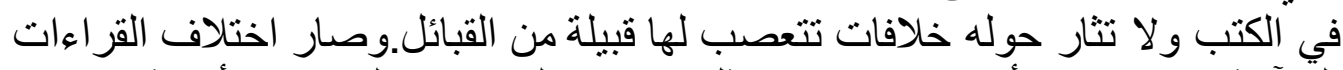

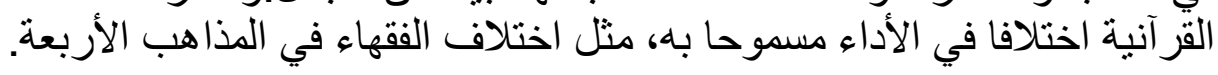

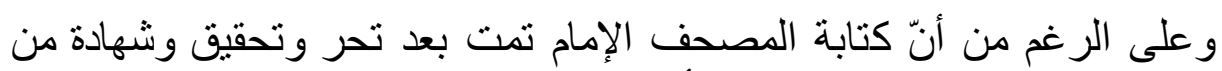

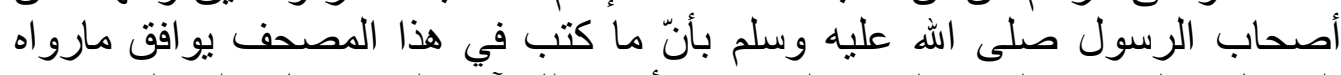

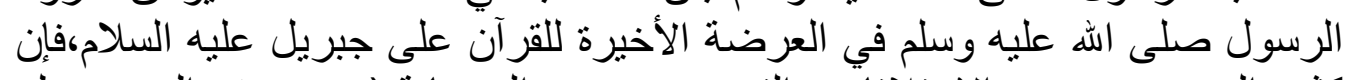

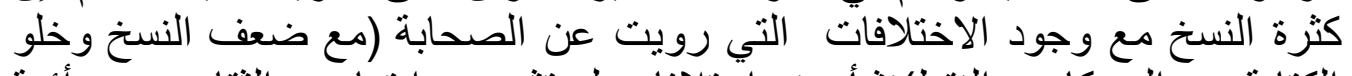

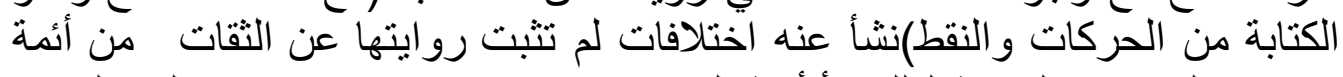

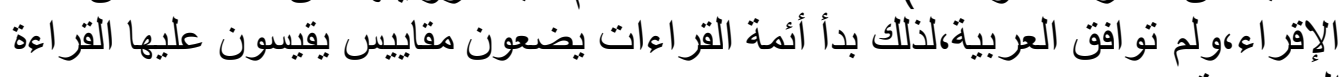

وبعد أكتمال ضبط المصحف بالحركات ونقط الحروف كتب المصحف بالرف الرسم

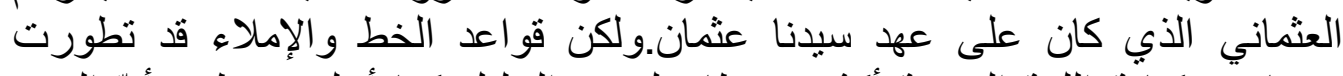

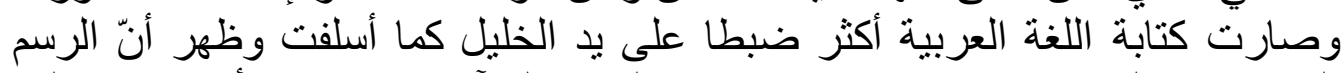

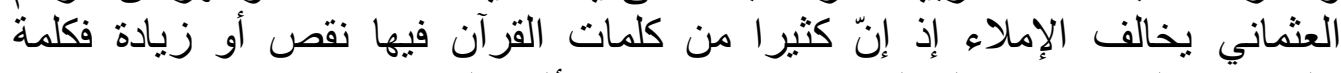

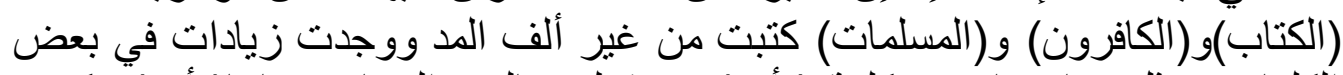

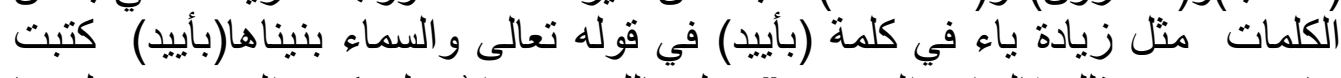

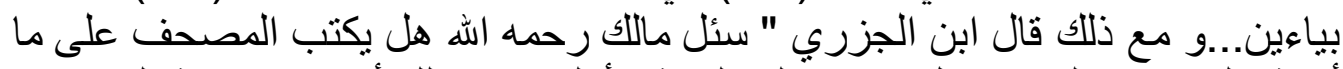

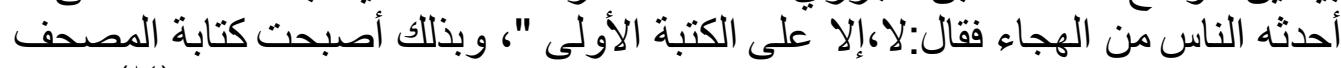

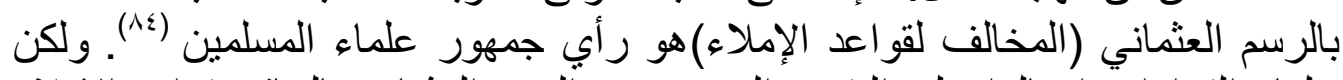

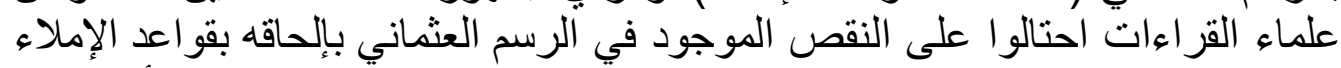

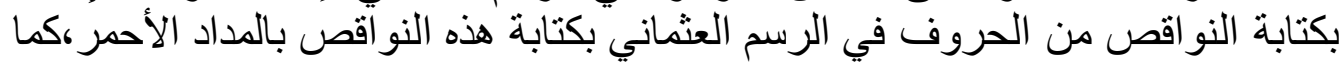

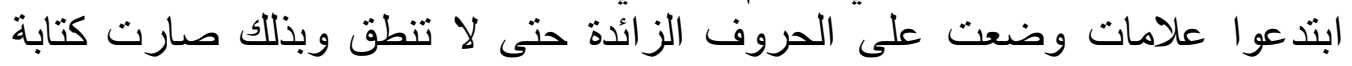


المصحف صوتية دقيقة وبعد ظهور المطابع الحديثة اتفق علماءالقراءات على إلى إبدال

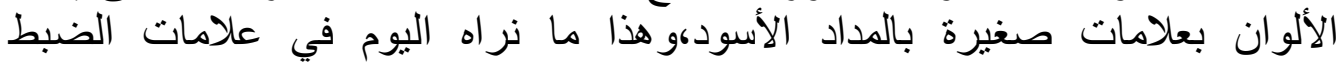
المشروحة في نهاية كل مصحف. بـ

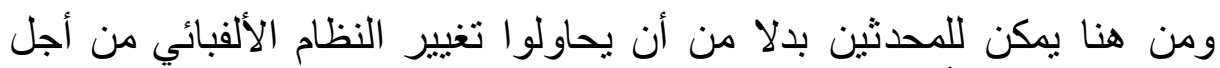

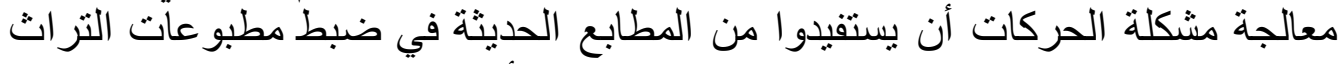
القديمة بتشكيلها بالحركات و العمل على التقبد بها في أي نشاط لغوي حتى تصني الفيح سليقة و عادة نطقية.

\section{ونخلص مما سبق للنتائج التالية:}

أنّ مصطلح (الصوائت والصوامت )ليس من وضع المستشرقين كما ذهب

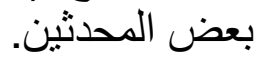

الحركات العربية هي في أصلها أوصاف للعملية التي يقوم بها الجهاز الصوتي من فتح الثفتين و انكسار هما و انضمي في اهمها. أنّ الحركة التي يتحملها الحرف هي في المرتبة بعده،

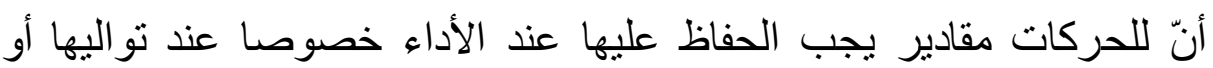

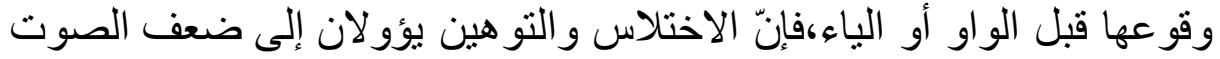

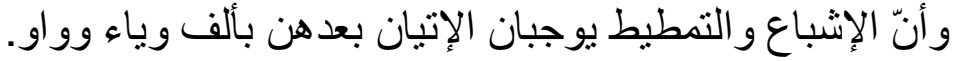

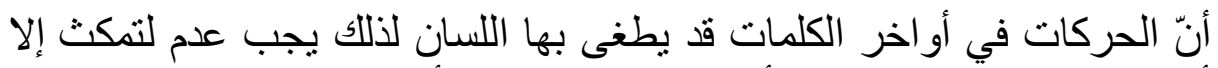

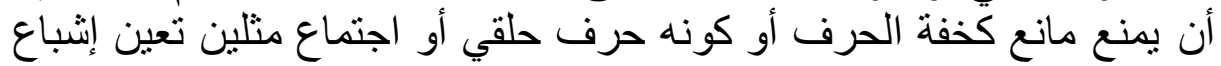
حركته

لم يعن المحدثون بوضع أقيسة للأصوات الصامتة كما فعلو ا في الصوائت الصو ائت أقوى وأوضح في السمع من الصو امت ـأصالة الدراسات اللغوية العربية القديمة،و عدم وجود تباين أوتضاد بينها وبين

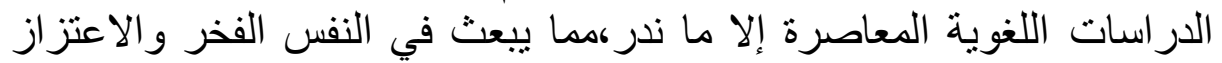

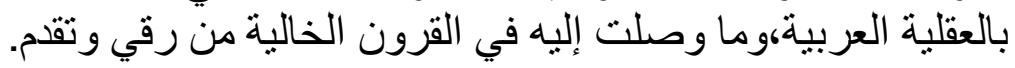


مجلة معالم الدعوة الإسلامية المحكمة العدد (الثامن)- صفر VT ا ا هـ / ديسمبر 10 • r م

ـ الاستفادة من المطابع الحديثة في ضبط مطبو عات التر اث القديمة بتشكيلها بالحركات

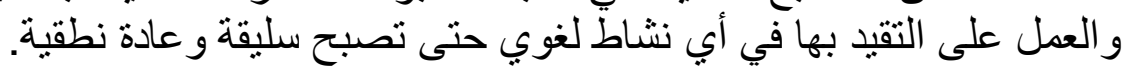




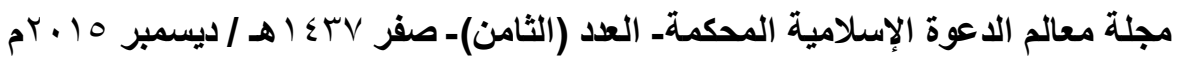

\section{الذهوامش}

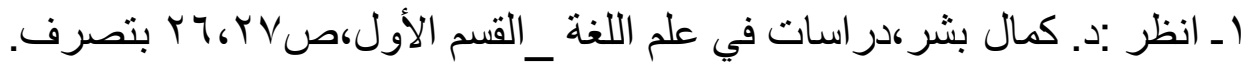

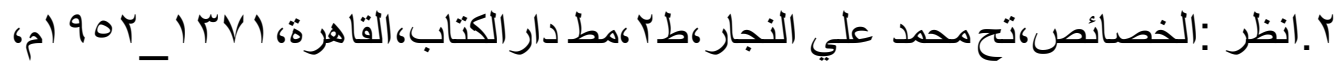
. I Y

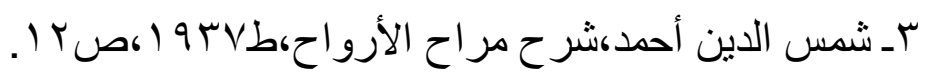

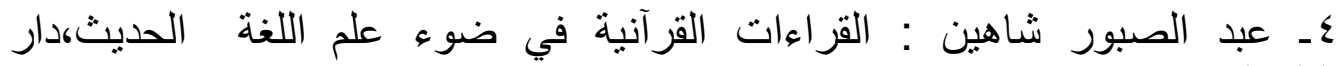
القلم، القاهرة،

○ـ ـ رمضان عبد التواب : في أصوات اللغة،محاضرات لطلبة الفرقة الثالثة بكلية

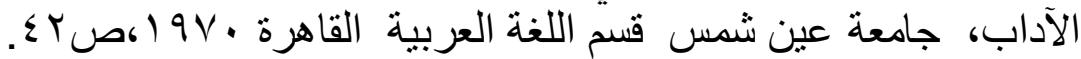

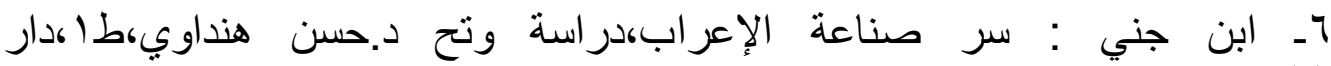

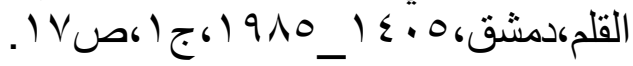

Vـ عبد الصبور شاهين : القراءات القر انية في ضوء علم اللغة الحديث،ص آبr. ^ـ رمضان عبد التواب : في أصوات اللغة، محاضر ات لطلبة الفرقة الثالثة جامعة عين

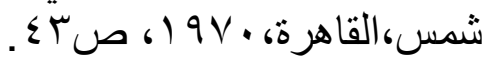

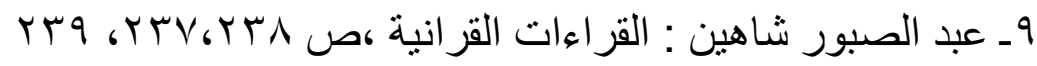
• 1 ـ عبد العال سالم مكرم :القران الكريم و أثزه في الدراسات النحوية، صلعـ. | إ يحي عبد الفتاح الدجني : أبو الأسود وننأة النحو العربي،صباجا.

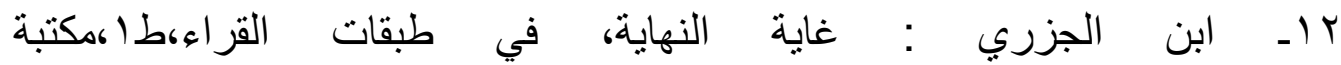

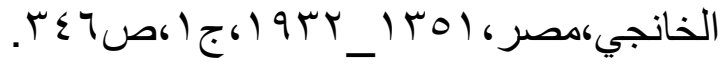
" ا ـ صحيح مسلم : جף، صو9.

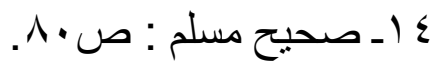

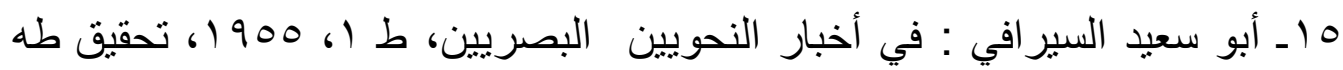

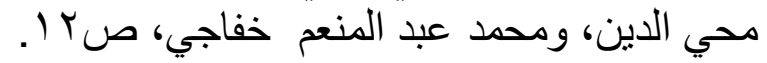




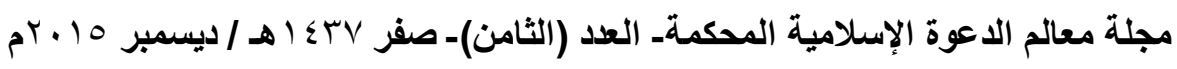

7 ا ــ أبو عمر عثمان الداني : المحكم في نقط المصاحف، صل ا، وينظر :شوقي ضيف،

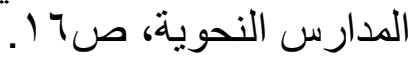

I ـ محمد خير الحلو اني : المفصل في تاريخ النحو، ج ا، صوج. 1 ا ـ وردت هذه الأشكال في كتاب ( أبو الأسود ونشأة النحو العربي)، فتحي عبد الفتاح

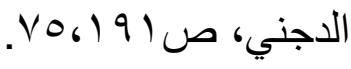

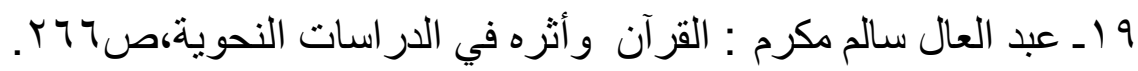

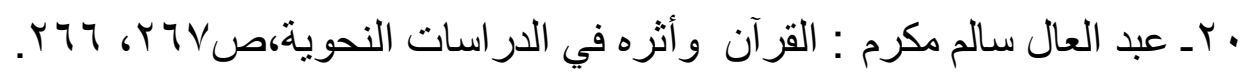
ا بـ جلال الدين السيوطي : بغية الوعاة في طبقات اللغوبين و النحاة، ج (كله. r ـ ـ مهدي المخزومي : مدرسة الكوفة ومنهجها في در اسة اللغة و النحو، صع . ؟. بr ـ لقد حافظت على المثال الذي ساقه مهدي النخزومي، وتصرفت في الترتيب.

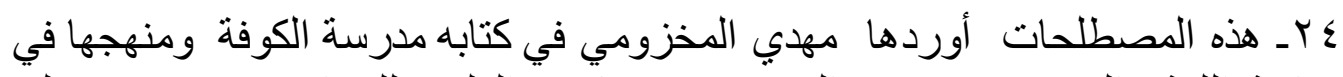

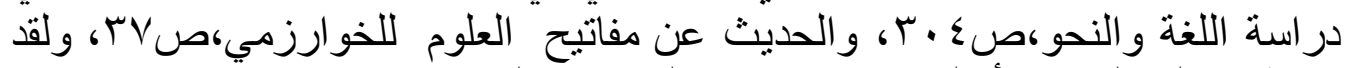

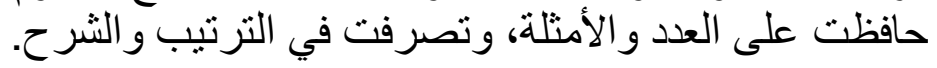

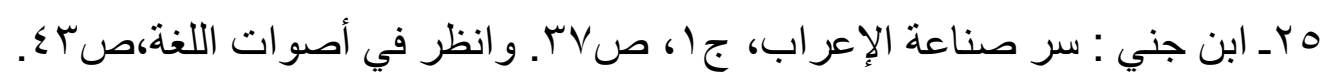

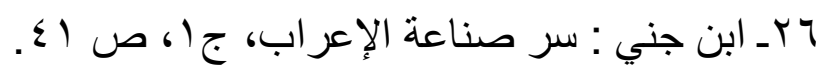

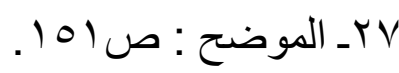
^ץ ـ و هذاما يعرف بالتغير ات التركيبية .

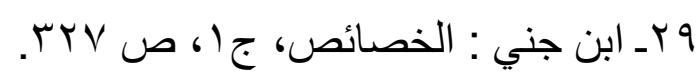
• ץ- حسام سعيد النعيمي : الدراسات الصوتية واللهجية عند ابن جني،منشورات

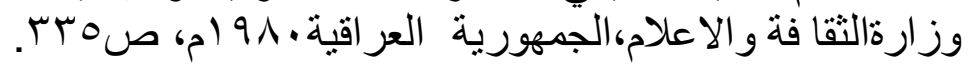

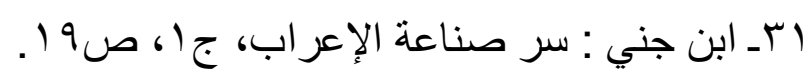

بــ الدر اسات الصوتية عند علماء التجويد : د. غانم قدوري، صم إع. 


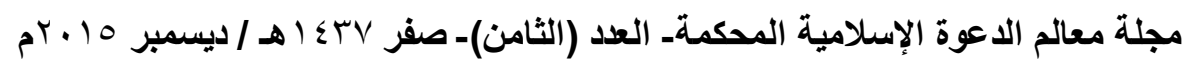

$$
\text { سז ـ الموضح : صسمرا. }
$$

ع זـ السابق :ص ب11)، وانظر الداني : التحديد،ص اس. هr ـ الموضح :

أبي

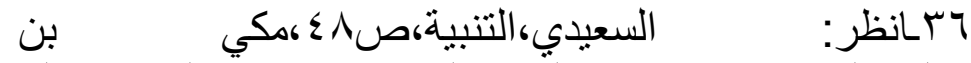

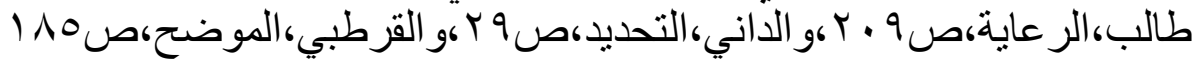

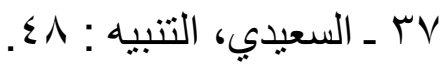

$$
\begin{aligned}
& \text { مبـ التحديد،الداني،ص }
\end{aligned}
$$

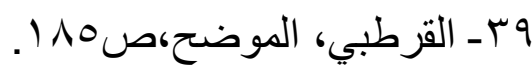

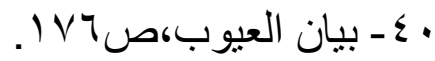

اء ـ الأصوات اللغوية، إبراهيم أنبس،ككتبة الأنجلو المصرية،طب 99 (م، صهץ

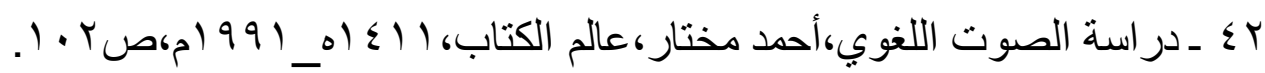
بـ ـ الأصو ات اللغوية، إبر اهيم أنيس،ص. بـ.

ع ــ علم الأصوات اللغوية،مناف مهدي محمد،الطبعة الأولى،9 (1 أهـ ص (9. ○ـ ـ انظر :الأصو ات اللغوية، إبر اهيم أنيس،ص.ب. 7 ـ - علم الأصو ات اللغوية،مناف مهدي محمد،ص الو. و التوز ـ علم الأصوات اللغوية : د. مناف مهدي محمد، عالم الكتاب للطباعة و النشر

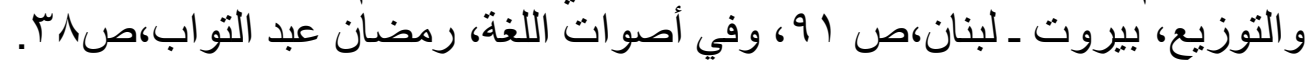
^ـ ـ ـ عبد الرحمن أيوب : الكلام انتاجه وتحليله،ط (،ذات السلاسل،الكويت، ع 9 (م،ص . 97

9؟ - سر صناعة الإعراب : ابن جني، جا، صـ.

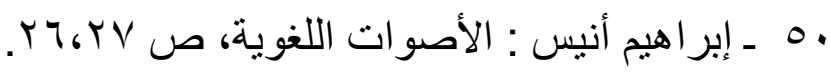




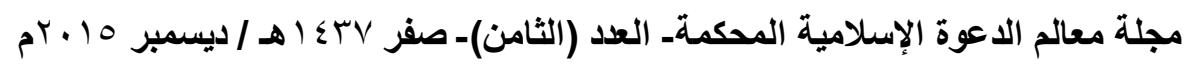

$$
\begin{aligned}
& \text { 10 ـ الأصو ات اللغوية : إبر اهيم أنيس، ص 9ץ. } \\
& \text { }
\end{aligned}
$$

هاه ـ دراسة الصوت اللغوي : أحمد مختار عمر، استاذ علم اللغة ـ كلية دار العلوم ـ

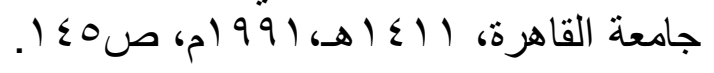

؟ ـ الأصو ات اللغوية : إبر اهيم أنيس، صاب.

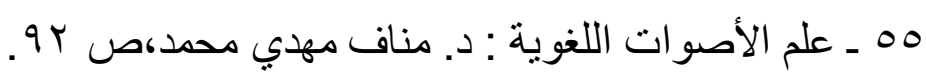

الهـ محمد منصف القماطي : الأصوات ووظائفهاهدار الولبد،طر ابلس،الجماهيرية

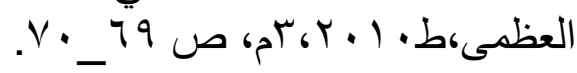

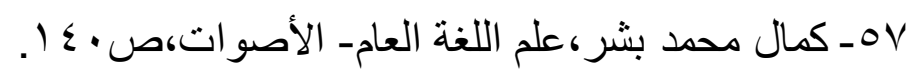

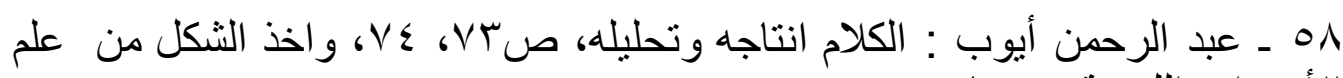

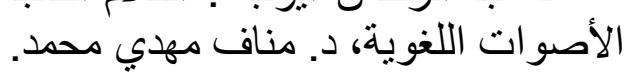

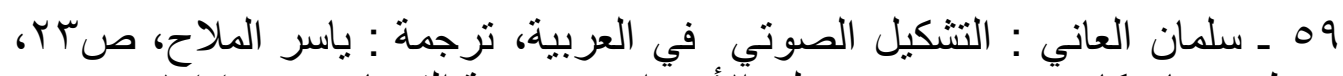

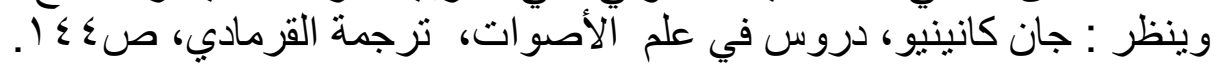

• آـ إبر اهيم أنيس : الأصوات اللغوية ، صآس، وينظر : كمال بشر : علم اللغة

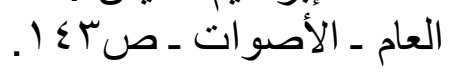

$$
\text { آ- إبر اهيم أنيس : الأصوات اللغوية ، ص. ب. }
$$

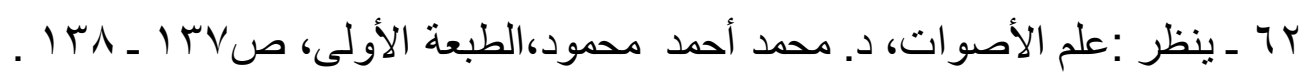
rاT_ محمد منصف القماطي : الأصو ات ووظائفها، صه V. ז ـ محمد منصف القماطي : الأصو ات ووظائفها، صهV.

هـ ـ سلمان العاني : التشكيل الصوتي في العربية، ترجمة ياسر الملاح، صل عـ. ד7- إبر اهيم أنيس : الأصوات اللغوية، صسب.

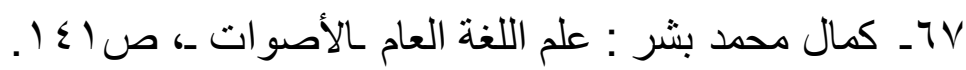




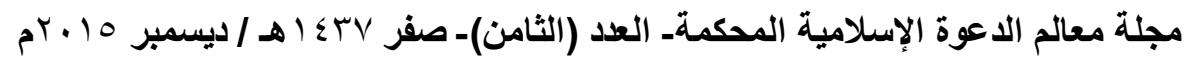

1 آـ د. جبور عبد النور و د. سهيل إدريس، قاموس المنهل ( فرنسي عربي )ط. دار

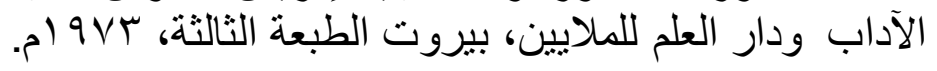
79 ـ محمد منصف القماطي : الأصوات ووظائفها،ص سV.

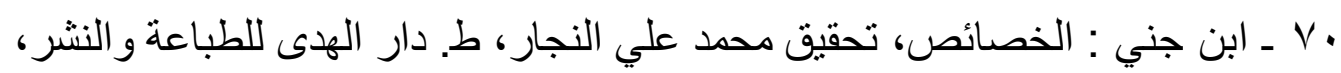

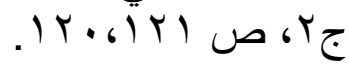
ا ال ابن جني : الخصائص، تحقيق محمد علي النجار، ط. دار الهدى للطباعة والنشر،

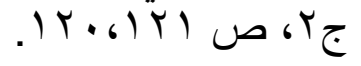

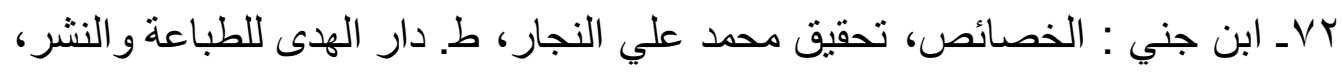

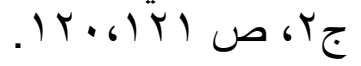

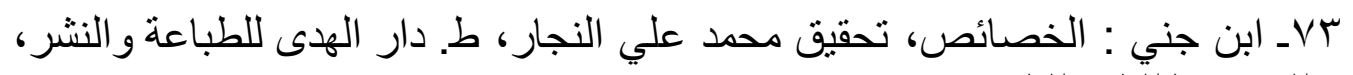

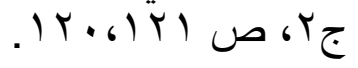

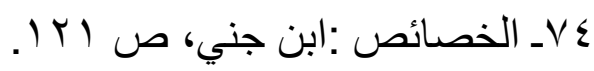
Vo

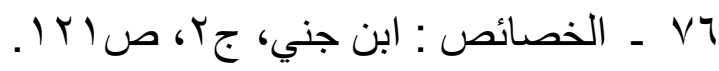
ـ ـ ع علم الأصو ات اللغوية : د. مناف مهدي محمد،ص سب. ـ ـ الأصو ات اللغوية : إبر اهيم أنيس، صع

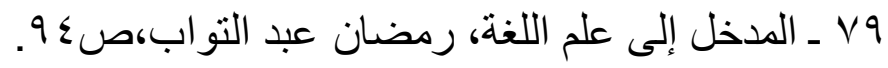
•ــ انظر: الأصوات اللغوية،د/.مناف مهدي محمد،.ص .. ـ ـ الأصوات اللغوية : د. إبر اهيم أنيس، صبك؛.

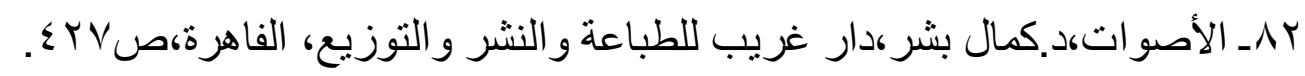
بیــ انظر:الأصوات،د.كمال بشر،دار غريب للطباعة و النشر والتوزيع، الفاهرة،ص EYA 
مجلة معالم الدعوة الإسلامية المحكمة. العدد (الثامن)- صفر VT ا هـ / ديسمبر 10 • r م

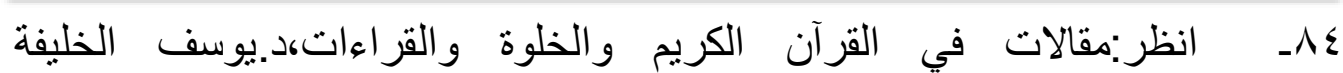

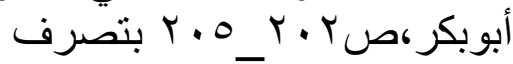

